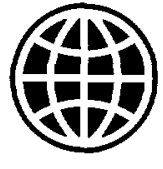

Work in progress for public discussion
WTP457 December 1999

\title{
Reforming Education in the Regions of Russia
}

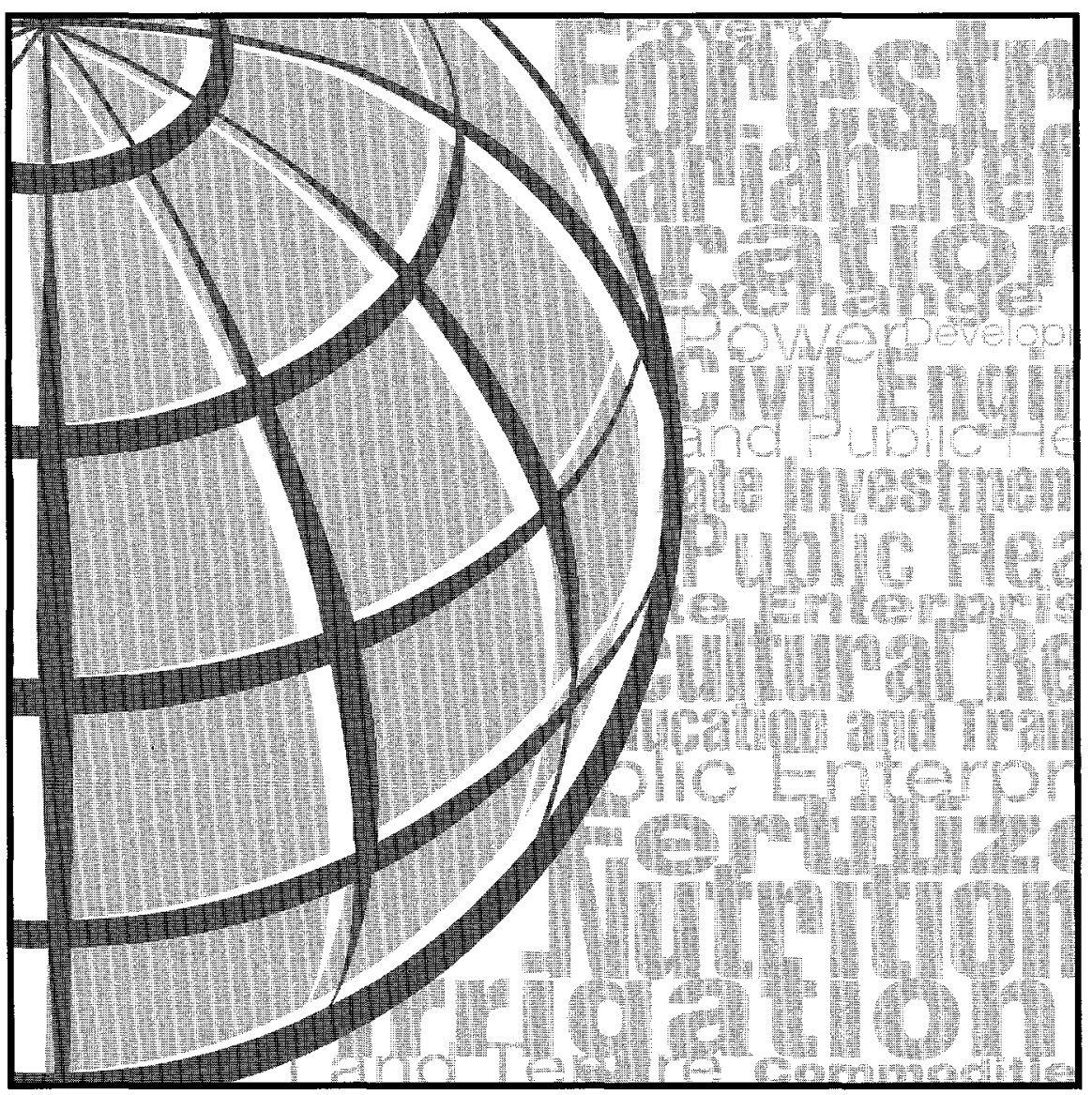

Mary Canning

Peter Moock

Timothy Heleniak 


\section{Recent World Bank Technical Papers}

No. 378 Shah and Nagpal, eds., Urban Air Quality Management Strategy in Asia: Kathmandu Valley Report

No. 379 Shah and Nagpal, eds., Urban Air Quality Management Strategy in Asia: Jakarta Report

No. 380 Shah and Nagpal, eds., Urban Air Quality Management Strategy in Asia: Metro Manila Report

No. 381 Shah and Nagpal, eds., Urban Air Quality Management Strategy in Asia: Greater Mumbai Report

No. 382 Barker, Tenenbaum, and Woolf, Governance and Regulation of Power Pools and System Operators: An International Comparison

No. 383 Goldman, Ergas, Ralph, and Felker, Technology Institutions and Policies: Their Role in Developing Technological Capability in Industry

No. 384 Kojima and Okada, Catching Up to Leadership: The Role of Technology Support Institutions in Japan's Casting Sector

No. 385 Rowat, Lubrano, and Porrata, Competition Policy and MERCOSUR

No. 386 Dinar and Subramanian, Water Pricing Experiences: An International Perspective

No. 387 Oskarsson, Berglund, Seling, Snellman, Stenbäck, and Fritz, A Planner's Guide for Selecting Clean-Coal Technologies for Power Plants

No. 388 Sanjayan, Shen, and Jansen, Experiences with Integrated-Conservation Development Projects in Asia

No. 389 International Commission on Irrigation and Drainage (ICID), Planning the Management, Operation, and Maintenance of Irrigation and Drainage Systems: A Guide for the Preparation of Strategies and Manuals

No. 390 Foster, Lawrence, and Morris, Groundwater in Urban Development: Assessing Management Needs and Formulating Policy Strategies

No. 391 Lovei and Weiss, Jr., Environmental Management and Institutions in OECD Countries" Lessons from Experience

No. 392 Felker, Chaudhuri, György, and Goldman, The Pharmaceutical Industry in India and Hungary: Policies, Institutions, and Technological Development

No. 393 Mohan, ed., Bibliography of Publications: Africa Region, 1990-97

No. 394 Hill and Shields, Incentives for Joint Forest Management in India: Analytical Methods and Case Studies

No. 395 Saleth and Dinar, Satisfying Urban Thirst: Water Supply Augmentation and Pricing Policy in Hyderabad City, India

No. 396 Kikeri, Privatization and Labor: What Happens to Workers When Governments Divest?

No. 397 Lovei, Phasing Out Lead from Gasoline: Worldwide Experience and Policy Implications

No. 398 Ayres, Anderson, and Hanrahan, Setting Priorities for Environmental MAnagement: An Application to the Mining Sector in Bolivia

No. 399 Kerf, Gray, Irwin, Lévesque, Taylor, and Klein, Concessions for Infrastructure: A Guide to Their Design and Award

No. 401 Benson and Clay, The Impact of Drought on Sub-Saharan African Economies: A Preliminary Examination

No. 402 Dinar, Mendelsohn, Evenson, Parikh, Sanghi, Kumar, McKinsey, and Lonergan, Measuring the Impact of Climate Change on Indian Agriculture

No. 403 Welch and Frémond, The Case-by-Case Approach to Privatization: Techniques and Examples

No. 404 Stephenson, Donnay, Frolova, Melnick, and Worzala, Improving Women's Health Services in the Russian Federation: Results of a Pilot Project.

No. 405 Onorato, Fox, and Strongman, World Bank Group Assistance for Minerals Sector Development and Reform in Member Countries

No. 406 Milazzo, Subsidies in World Fisheries: A Reexamination

No. 407 Wiens and Guadagni, Designing Rules for Demand-Driven Rural Investment Funds: The Latin American Experience

No. 408 Donovan and Frank, Soil Fertility Management in Sub-Saharan Africa

No. 409 Heggie and Vickers, Commercial Management and Financing of Roads

No. 410 Sayeg, Successful Conversion to Unleaded Gasoline in Thailand

No. 411 Calvo, Options for Managing and Financing Rural Transport Infrastructure

No. 413 Langford, Forster, and Malcolm, Toward a Financially Sustainable Irrigation System: Lessons from the State of Victoria, Australia, 1984-1994 
WORLD BANK TECHNICAL PAPER NO. 457

\section{Reforming Education in the Regions of Russia}

Mary Canning

Peter Moock

Timothy Heleniak

The World Bank

Washington, D.C. 
Copyright (C) 1999

The International Bank for Reconstruction

and Development/THE WORLD BANK

1818 H Street, N.W.

Washington, D.C. 20433, U.S.A.

All rights reserved

Manufactured in the United States of America

First printing December 1999

Technical Papers are published to communicate the results of the Bank's work to the development community with the least possible delay. The typescript of this paper therefore has not been prepared in accordance with the procedures appropriate to formal printed texts, and the World Bank accepts no responsibility for errors. Some sources cited in this paper may be informal documents that are not readily available.

The findings, interpretations, and conclusions expressed in this paper are entirely those of the author(s) and should not be attributed in any manner to the World Bank, to its affiliated organizations, or to members of its Board of Executive Directors or the countries they represent. The World Bank does not guarantee the accuracy of the data included in this publication and accepts no responsibility for any consequence of their use. The boundaries, colors, denominations, and other information shown on any map in this volume do not imply on the part of the World Bank Group any judgment on the legal status of any territory or the endorsement or acceptance of such boundaries.

The material in this publication is copyrighted. The World Bank encourages dissemination of its work and will normally grant permission promptly.

Permission to photocopy items for internal or personal use, for the internal or personal use of specific clients, or for educational classroom use, is granted by the World Bank, provided that the appropriate fee is paid directly to Copyright Clearance Center, Inc., 222 Rosewood Drive, Danvers, MA 01923, U.S.A., telephone 978-750-8400, fax 978-750-4470. Please contact the Copyright Clearance Center before photocopying items.

For permission to reprint individual articles or chapters, please fax your request with complete information to the Republication Department, Copyright Clearance Center, fax 978-750-4470.

All other queries on rights and licenses should be addressed to the World Bank at the address above or faxed to 202-522-2422.

ISBN: 0-8213-4624-5

ISSN: 0253-7494

Mary Canning is a principal operations officer in the Human Development Sector Unit of the World Bank's Europe and Central Asia Region. Peter Moock is a principal economist in the Human Development Sector Unit of the World Bank's East Asia and the Pacific Region. Timothy Heleniak is a consultant in the Development Data Group of the World Bank's Development Economics Group.

Library of Congress Cataloging-in-Publication Data has been applied for. 
WORLD BANK TECHNICAL PAPER NO. 457

\section{Reforming Education in the Regions of Russia}

Mary Canning

Peter Moock

Timothy Heleniak

The World Bank

Washington, D.C. 
Copyright $(1999$

The International Bank for Reconstruction

and Development/THE WORLD BANK

1818 H Street, N.W.

Washington, D.C. 20433, U.S.A.

All rights reserved

Manufactured in the United States of America

First printing December 1999

Technical Papers are published to communicate the results of the Bank's work to the development community with the least possible delay. The typescript of this paper therefore has not been prepared in accordance with the procedures appropriate to formal printed texts, and the World Bank accepts no responsibility for errors. Some sources cited in this paper may be informal documents that are not readily available.

The findings, interpretations, and conclusions expressed in this paper are entirely those of the author(s) and should not be attributed in any manner to the World Bank, to its affiliated organizations, or to members of its Board of Executive Directors or the countries they represent. The World Bank does not guarantee the accuracy of the data included in this publication and accepts no responsibility for any consequence of their use. The boundaries, colors, denominations, and other information shown on any map in this volume do not imply on the part of the World Bank Group any judgment on the legal status of any territory or the endorsement or acceptance of such boundaries.

The material in this publication is copyrighted. The World Bank encourages dissemination of its work and will normally grant permission promptly.

Permission to photocopy items for internal or personal use, for the internal or personal use of specific clients, or for educational classroom use, is granted by the World Bank, provided that the appropriate fee is paid directly to Copyright Clearance Center, Inc., 222 Rosewood Drive, Danvers, MA 01923, U.S.A., telephone 978-750-8400, fax 978-750-4470. Please contact the Copyright Clearance Center before photocopying items.

For permission to reprint individual articles or chapters, please fax your request with complete information to the Republication Department, Copyright Clearance Center, fax 978-750-4470.

All other queries on rights and licenses should be addressed to the World Bank at the address above or faxed to $202-522-2422$.

ISBN: 0-8213-4624-5

ISSN: 0253-7494

Mary Canning is a principal operations officer in the Human Development Sector Unit of the World Bank's Europe and Central Asia Region. Peter Moock is a principal economist in the Human Development Sector Unit of the World Bank's East Asia and the Pacific Region. Timothy Heleniak is a consultant in the Development Data Group of the World Bank's Development Economics Group.

\section{Library of Congress Cataloging-in-Publication Data has been applied for.}




\section{CONTENTS}

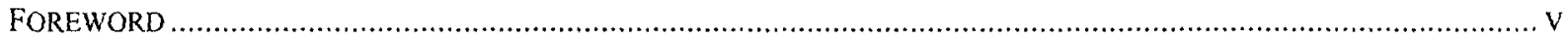

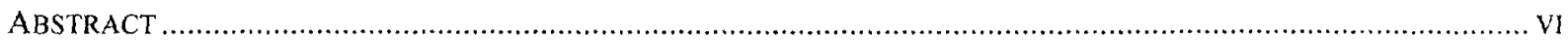

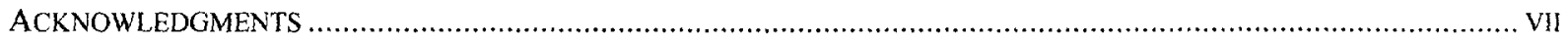

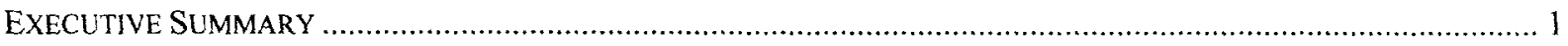

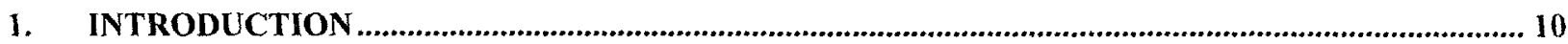

BACKGROUND: EDUCATION REFORM IN THE RUSSIAN FEDERATION ….................................................. 10

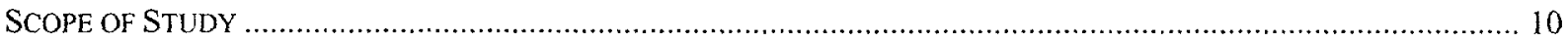

METHODOLOGY

ISSUES

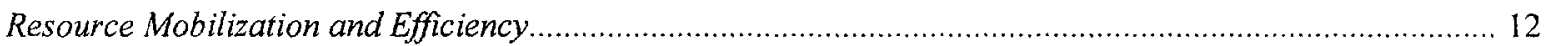

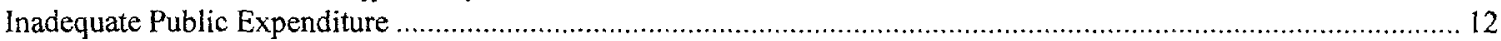

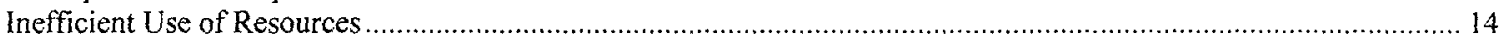

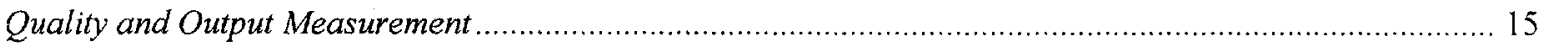

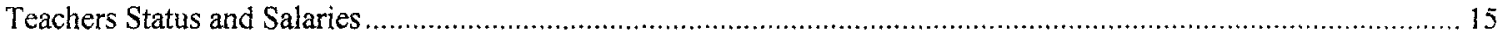

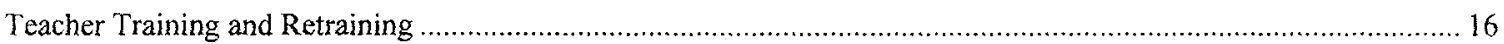

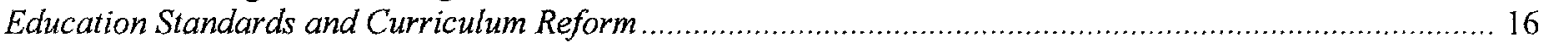

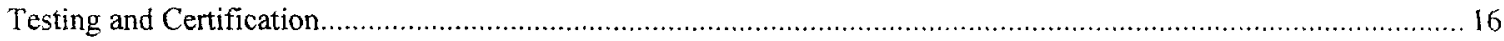

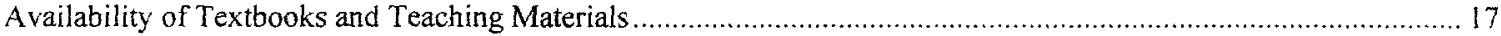

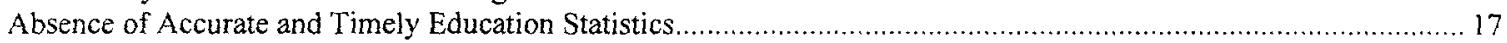

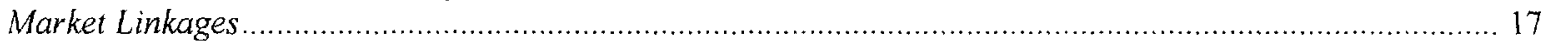

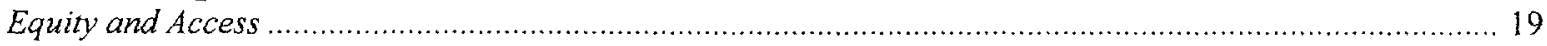

2. NATIONAL AND REGIONAL TRENDS IN THE DEMAND AND SUPPLY OF EDUCATIONAL

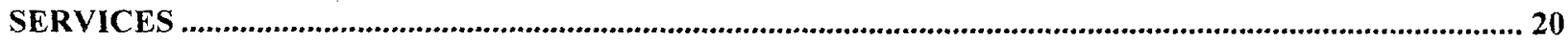

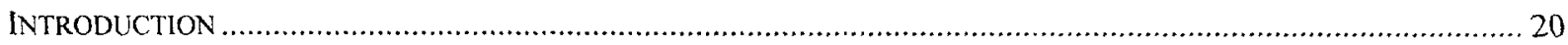

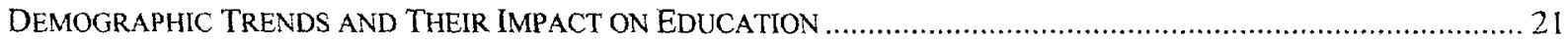

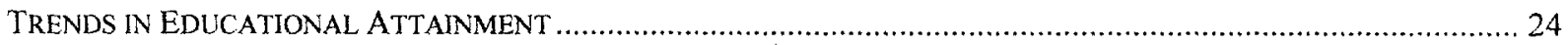

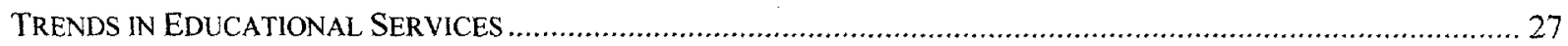

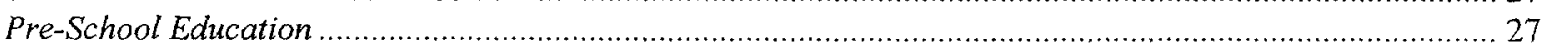

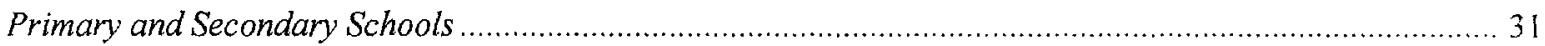

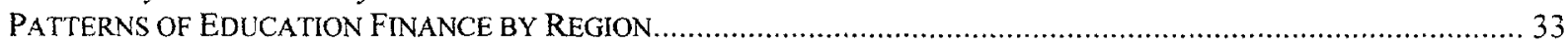

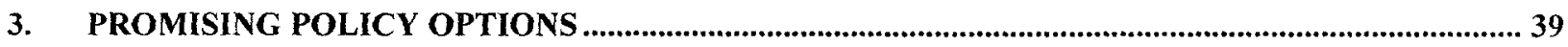

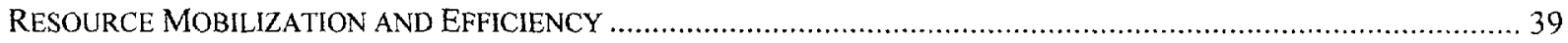

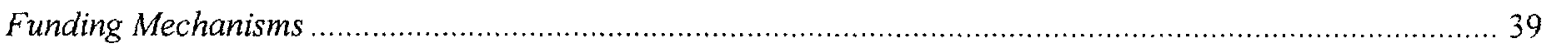

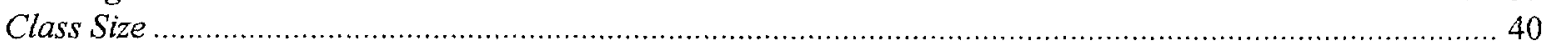

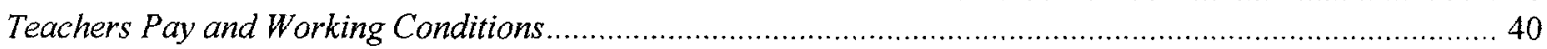

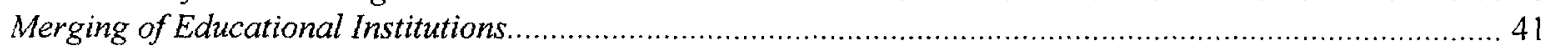

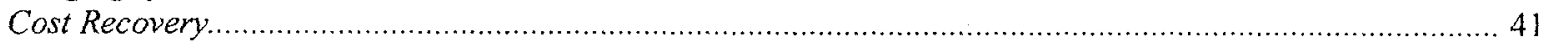

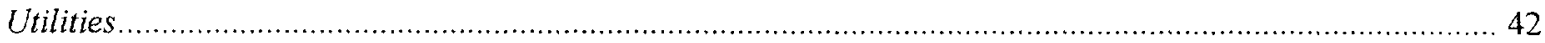

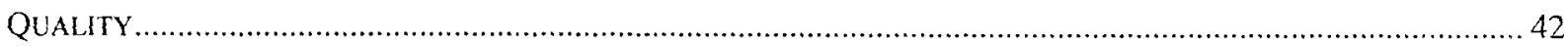

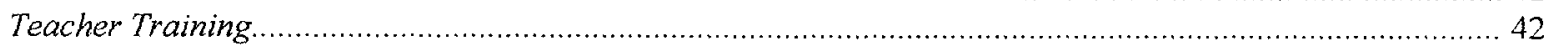

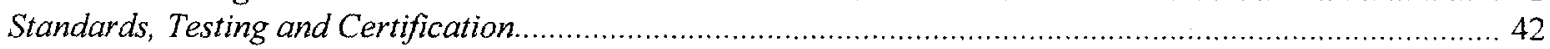

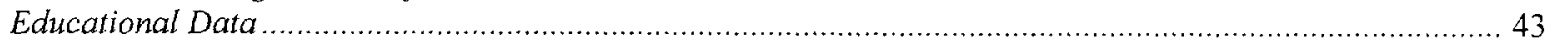

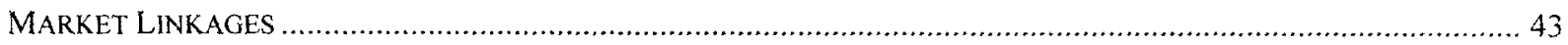

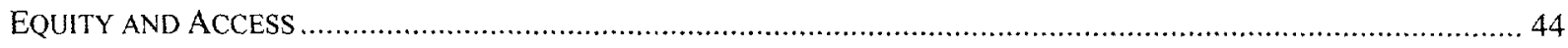

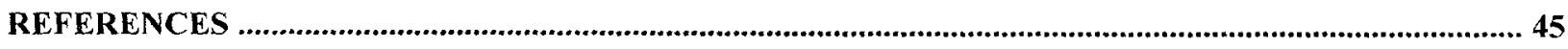

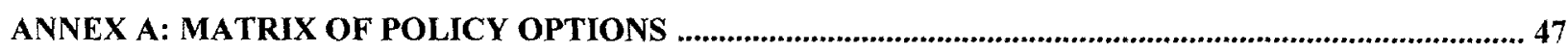

ANNEX B: SELECTED DATA ON EDUCATION FINANCE IN RUSSIA, 1989-1997 ................................. 50 
ANNEX D: SAMARA REGION

ANNEX E: NOVGOROD VILIKI REGION .............................................................................................................67

ANNEX F: SELECTED DATA ON SAMARA AND NOVGOROD VILIKI............................................................76

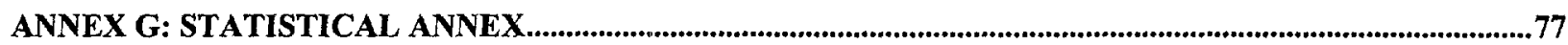

\section{FIGURES}

Figure 2.1 Age-Sex Structure of the Population of Russia, 1996 .22

Figure 2.2 School-Age Population as a Share of the Total Population by Economic

Region, 1989 and 1997 (15 years and younger)

Figure 2.3 Change in the School-Age Population by Region, 1989-1997 ............................................................25

Figure 2.4 Level of Education of the Population of Russia, 1979, 1989 and 1994 ..............................................26

Figure 2.5 Educational Attainment of the Population by Region, 1994 …......................................................28

Figure 2.6 Changes in the Shares of Population with Higher and Specialized Secondary

Education by Economic region, 1989 to 1994 (per 1,000 persons 15 and older)......................................29

Figure 2.7 Pre-Schools in Russia by Subordination, 1989-1996 ........................................................................30

Figure 2.8 Selected Data on Pre-Schools in Russia, 1989-1996 ..................................................................

Figure 2.9 Enrollment Rates by Level of Education, 1989-1996 ..................................................................

Figure 2.10 Student-Teacher Ratios in Compulsory Education in Russia, 1989-1996...........................................33

Figure 2.11 Number of Students in Professional-Technical Institutions (PTUs)

and Specialized Secondary Institutions (SSIs), 1990-1996

Figure 2.12 Wages of Education Workers versus National Average....................................................................38

Figure 2.13 Construction of New School Places by Level of Education, 1989-1996..............................................38

TABLE

Table 2.1 Age Composition of Russia, 1989-2010 (thousands) 


\section{FOREWORD}

The education sector in Russ ia is one with a proud tradition. Most school-age children have access to school places, and nearly all adults in the population are literate. Under central planning, however, the education system operated without incentives for promoting accountability and efficiency. Early efforts at reform included the rapid decentralization of responsibilities for general education to regions, often without commensurate transfer of resources for the regions to maintain and operate this system satisfactorily. The worsening fiscal base, as well as confusion about roles and responsibilities at each level of government, have contributed to growing inefficiencies and poor articulation between the outputs of the education system and the needs of the emerging market economy. This unclear devolution of responsibility, while creating new opportunities for the system to become more responsive to local needs, is placing new burdens on administrators in all regions by asking them to fulfil roles for which they are untrained and often lack the necessary funding. There is, in addition, growing concern that the quality of education services is being compromised by the shrinking resource base and by weak institutional development that undermines the capacity to implement reform. On the positive side, however, decentralization may have increased parental choice and school autonomy.

Based on the analysis of dat a and visits to the education systems of Saratov, Samara and Novgorod, this study identifies four areas in Russia's education sector where there are major issues to be addressed: (1) resource mobilization and efficiency, (2) quality and output measurement, (3) market linkages, and (4) equity and access. By setting a framework of policy options, the study makes a significant contribution to understanding the implications and assessing the viability of the reforms.

Although education reform in Russia has its own unique context, this report should be of much wider interest to the policy-makers and professional practitioners who are grappling with the education system decentralization process which is under way in many countries of the Europe and Central Asia region, as well as in other parts of the world. It is in this context of promoting the sharing of knowledge and experience that this report on the case of Russia is being published in the Bank's Technical Papers series. We hope that scholars and practitioners will find it of interest and use.

\author{
Michael Carter \\ Country Director for Russia \\ Europe and Central Asia Region
}

\author{
Chris Lovelace \\ Acting Sector Director \\ Human Development Unit \\ Europe \& Central Asia Region
}




\begin{abstract}
Russia's educational system, with broad access, and high levels of scholarly achievement, has long been a source of strength. The Soviet system, however, was grossly overcentralized, inefficient and lacking in accountability. In the last decade, attempted rapid decentralization has not been well designed, since there has been no commensurate transfer of resources and levels of responsibility have remained unclear. Unless corrected soon, the harmful impact on educational quality and equity could be very serious. The purposes of this report are to analyze the nature of the current problems and to discuss policy options open to the Russian Government in its efforts to improve educational efficiency, preserving and even improving equitable access, without sacrificing traditions of academic excellence. This report is based on analysis of trends across the 89 Russian regions and case studies.

The study analyzes General and first level Vocational Education under four main headings: (i) efficiency of resource use; (ii) quality; (jii) market relevance and (iv) equity. The study highlights the fact that the number of teachers has been growing three times as fast as the number of students, but that both teachers and school administrators face a set of adverse incentives and frequently lack essential complementary resources such as adequate textbooks. The educational system, especially vocational education, is poorly equipped to respond to rapidly changing market incentives. Resource shortages are having a particularly severe effect in poorer Regions so that decentralization may be worsening interregional inequalities, while within regions rural schools and those catering for minority populations or for children with special needs seem especially hard hit. The two case studies both illustrate the problems and also show that some Regions have been innovative in seeking solutions to these problems.

In its conclusions, the Report draws on this Regional experience to suggest reform options. Among other proposals, efficiency could be increased by giving schools increased financial autonomy, using of per capita financing formulae, and beginning to rationalize the teaching force and improve its quality. A national system of student assessment might help both to raise quality and improve the equity of access to highly selective institutions. Reforms are required to improve the market responsiveness of first-level vocational education, and especially to avoid excessive and premature specialization.
\end{abstract}




\section{ACKNOWLEDGMENTS}

Many individuals contributed to this report. We are grateful for the assistance of Helen Shahriari and Mark Agranovitch. Lev Freinkman and Harry Patrinos provided invaluable comments as Peer Reviewers. A special thanks to IIdiko Beszedes and Annie Milanzi for the tireless processing of the report. Michael Carter, Country Director, gave us the wide experience of country knowledge. Without the guidance and support of James Socknat, Sector Leader, and Chris Lovelace, Sector Director, this paper would not have been possible.

We would especially like to thank our counterparts in the Russian Federation who provided valuable comments and feedback including the Minister, several Deputy Ministers and senior officials of the Ministry of Education of the Russian Federation; the Education Directors and senior staff of the Regional Administration of Saratov, Novgorod Viliki and Samara Regions and many members of the education community in Russia. 



\section{EXECUTIVE SUMMARY}

The Regional Education study was undertaken by the World Bank at the request of the Ministry of General and Professional Education (MGPE). ${ }^{l}$ A major purpose of the study was to identify key issues in pre-university education (general, primary and secondary, as well as vocational secondary) in order to assist Government's efforts to articulate and implement its program of education reform. The findings of the study will inform the future operational work of the World Bank in Russian education.

\section{BACKGROUND}

Russian education has a proud tradition. Most school-age children have access to school places, and nearly all adults in the population are literate. The excessively centralized Soviet education system, however, operated without incentives to be efficient and with inadequate accountability. Early efforts at reform included a rapid decentralization of responsibilities for general education to the regions, but there was no commensurate transfer of resources, and the roles and responsibilities at each level of government were often unclear. Although creating new opportunities for the system to become more responsive to local needs, this has placed new burdens on administrators in all regions and assigned them roles for which they are untrained. Problems were greatly worsened by the severe fiscal stringency. The MGPE estimates that public spending on education and training per student fell at a rate of between 5 and 10 percent per year (in real terms) between 1991 and 1996. Since the devaluation of the rouble in August 1998 the situation has worsened considerably. GDP per capita fell to $\$ 1,937$ in 1998 , (only $60 \%$ of its 1991 level in current dollars) and a preliminary estimate puts education spending in 1998 at just 3 percent of GDP. A further steep decline in GDP is expected in 1999.

\section{STRUCTURE OF THE REPORT}

Chapter 1 of this report presents major issues in Russian education, identified through primary and secondary data analysis and in discussions with Russian educators. Chapter 2 addresses differences in education provision across Russia and demonstrates growing inequalities in how funds are allocated and spent at regional and sub-regional levels, through an analysis of budgetary trends in the 89 Regions. Chapter 3 lays out promising policy options. Detailed descriptions of the contrasting educational situations and reform efforts in Samara and Novgorod, together with data tables that demonstrate the developments in Russia's transition to a market-based education service system, are given in the annexes to this report.

\section{Methodology}

In December 1997, an initial visit was made to Saratov region, chosen because its leadership is implementing a program of educational reform. Subsequently, data were collected from the regional and sub-regional offices in a further seven regions on educational expenditures, student enrollments, the budgeting process, systems of management, budgetary transfers from the federal government, inter-raion budgetary transfers within the oblast, private sources of financing and non-public provision of education. A second and larger mission in March 1998 included visits to two of the seven regions, Samara and Novgorod, to explore in greater depth the questionnaire results and to conduct interviews with teachers, parents, education administrators and other professionals.

The Ministry of General and Professional Education was renamed the Ministry of Education in June 1999. 


\section{ISSUES}

The study identifies four areas in Russia's pre-university education sector where there are major issues to be addressed: (1) resource mobilization and efficiency, (2) quality and output measurement, (3) market linkages, and (4) equity and access.

\section{Resource Mobilization and Efficiency}

Compulsory education, like other functions of the regions, is supported (in the case of "receiving" regions) by federal transfers from central government to the regions. Federal transfers have fallen, however, during the $1990 \mathrm{~s}$-- both in real terms and relative to what the regions themselves spend. Furthermore, in most cases these transfers are not earmarked but take the form of general block grants which regional authorities can allocate as they see fit, and there is evidence that education is not always given high priority. Indeed, even in the extraordinary circumstances in which transfers earmarked for education have been made, it appears that these have not fully reached their target. This has happened during crises over wage arrears, with transfers earmarked for education sector wages reallocated to other sectors. Most preschool education has been handed over to municipal authorities which increases their financial burden. Fiscal difficulties have also resulted in reduced Federal Government financing of professional education, most especially at the first-level of vocational education.

Scarce resources are also fre quently used inefficiently. Nationally, the number of teachers has been growing three times as fast as students: the student-teacher ratio has declined from 15.8 in 1989 to 13.5 in 1996. While lower student-teacher ratios and smaller classes are preferred by most teachers and may facilitate the educational process, these advantages come at a high cost. Student-teacher ratios are likely to fall further in the years ahead as the smaller cohorts resulting from lower birthrates pass through Russia's school system. Federal regulations, however, unnecessarily limit regional freedom to raise student-teacher ratios in compulsory education. Federal laws specify that no class should exceed 25 students in number. Serious problems arise in rural schools with very few students. The study team was told of class-groups of 3-5 students in the regions visited. The proportion of non-teaching staff also tends to be high in Russian schools, which is at least partly the result of diseconomies of scale of running many small institutions, meaning that the fixed costs of administration are spread over too few students.

Most schools do not have their own bank accounts which reduces the accountability of school administrators for the private funds mobilized. There is also a general problem that subnational governments often lack the capacity to direct their own expenditures. An example of the problems that can arise is that of utilities arrears where schools cannot pay for their heat or electricity and where the utilities companies, in turn, do not pay taxes equivalent to the shortfall from public institutions. The impact of such inefficiencies (which contracting budgets tend to compound and make worse) on educational access and quality is perhaps just beginning to be felt.

The most serious expenditure problem is that of teachers' pay. The teaching profession has been particularly demoralized during the last five years by having their low salaries frequently paid in arrears while, at the same time, other job benefits are also disappearing. Salaries are so meager that they are an impediment to recruiting and retaining good teaching staff. Moreover, incentives for existing teachers and school directors to learn new pedagogical or management skills are minimal, and this in turn encourages the perpetuation of a rigid, hierarchical and inefficient system.

As schools gain greater autonomy, it will also be necessary to train School Directors and education administration personnel in local government offices in management, particularly financial management. 


\section{Quality and Output Measurement}

There is a pervasive lack of access to new teaching materials, equipment, visual aids and information about new teaching methodologies. In order to improve quality and initiate pedagogical and curricular reform, teachers will require new training in classroom management and in updated pedagogical methods. There is a shortage of modern school textbooks and learning aids in certain key subject areas, such as civics, history, economics and languages. Teachers' manuals and other information for teachers facing new challenges in the classroom are lacking in many schools. The shortage is particularly acute for vocational education, which needs new materials to reflect market needs.

There is a need to develop more competency-based and individualized approaches to learning in a student-centered classroom environment, in contrast to the currently excessive rote learning. Core education programs need to be modernized to encourage problem-solving, innovative thinking and creativity in the classroom. New teacher training, testing, assessment, examinations and qualifications arrangements will be needed to reflect these developments.

In trying to maintain the level of education inputs and ensure the quality of education outputs, educational administrators and professionals encounter the same lack of clarity of the roles and responsibilities of different levels of government. Ensuring educational quality is a prime responsibility of MPGE, but it must operate through stakeholders at a community level. Since 1992 work has been undertaken to develop minimum standards and assessment and testing systems, as well as to reform accreditation and quality evaluation to meet the needs of the market and modern life, but standards are still defined as inputs to the learning process rather than as student outcomes. There is also no mechanism by which MGPE can monitor and evaluate the quality of education programs throughout Russia. At Regional level, local authorities are unable to deliver evaluations of school quality and management owing to a lack of capacity.

Diversified and decentralized education systems require reliable forms of "output" measurement. This places an additional burden on MGPE, which lacks an objective and fair system of student assessment to ensure comparability of results across ethnically and geographically disparate regions. Moreover, in the absence of reliable assessment for school-leavers, higher education institutions are obliged to organize their own entrance examinations, which consume scarce financial resources and raise questions about objectivity and fairness. Nationally recognized certification is especially important for those leaving the vocational education system.

Russia lacks an accurate, easily accessible database from which policy makers or educational managers can assemble information about student numbers, unit costs and achievement levels. To date, there is little understanding that the development of such education statistical data could have added value for policy makers.

\section{Market Linkages}

Neither general secondary education nor vocational education is well equipped to respond to market signals and to reflect the rapidly changing conditions in Russia today. Vocational education institutions have had particular difficulty in adapting to the changing social and economic environment, and many are still not oriented towards current labor market needs. Some regions have taken the initiative to integrate and restructure vocational institutions, and new Federal guidelines reduce the number of vocational specializations. However, much remains to be done. A systemic reform of the vocational education system is needed, and the ongoing process of decentralization points to regional, rather than federal, solutions as the most appropriate. 


\section{Equity and Access}

The historical strength of Russian education was its commitment to equity and access, regardless of ethnic background, gender or geographical location. Secondary school elitism is not of course new, but it is especially fostered by the present fiscal climate, and can lead to a situation where special linkages between particular universities and feeder schools are cultivated from grade 10 onwards (and sometimes even earlier than grade 10). This system is open to abuse. Early specialization and the streaming of students in the secondary system may be inefficient because "late bloomers" are often sidelined and not given the kind of education that will equip them to function in the market economy. It also has serious equity implications, since the ability to pay often influences admission to extra courses and, in some cases, access to the school itself and may narrow educational choice and opportunities open to intellectually competent students from poor families.

There is now a danger that although educational and fiscal decentralization are desirable the net effect in a time of fiscal crisis may be to increase inter-regional inequality among schools. In addition, the application of rigid funding formulae (if implemented) could have inequitable consequences for the distribution of funds within a region. Evidence from the study team's visits to Samara andNovgorod in March 1998 confirms the difficult choice facing regional administrators who may have to choose between heating schools during cold winter months and paying teachers' salaries on time; or raion administrators, between keeping hospitals open and paying teachers. In these conditions, it seems inevitable that the necessity for frugal budget management inside a less well-off region will undermine support for, inter alia, rural schools, special schools, minority pupils and those coming from "at risk" families, unless a practical "weighting factor" for special needs can be developed.

\section{Regional Variations in Education Provision}

Findings of the study demonstrate that, while higher levels of expenditure do not necessarily translate into higher educational outcomes, nevertheless, across the board, Russia's poorest regions are now struggling to maintain even the most basic educational services. The Annexes on Samara and Novgorod Regions offer interesting and contrasting examples of how Regional Education Administration officials are dealing with the problems of managing the system with scarce resources.

\section{Samara}

Samara, although a donor region, has initiated a series of reforms to use existing budgetary resources more efficiently so as to raise the quality of education. The administration's assessment of the traditional system of education finance in Samara (which would be found as well in most other parts of the Russian Federation) is that public financing was "supporting the process but not the results" of education and training. In many rural schools, classes of 5-to-10 students were not uncommon, even when a school was close to a much larger school in the central town of the raion. The Samara Education Administration rightly concluded that such staffing allocations were not sustainable in today's resource constrained environment.

Starting in 1998, Samara has introduced the following reforms:

- The introduction, on a trial basis, of a new funding formula for the allocation of oblast subventions given for education to receiving raions in the Region. Samara refers to this new system as "normative financing," essentially a capitation system whereby "money follows students."

- A second change introduced in Samara Region in 1998 amounts to an earmarking of oblast subventions transferred to receiving raions and intended for education. There was a growing concern, 
however, at the oblast level and within the education sector that some raions were diverting resources and increasing the local support for other services at the expense of education.

- A third reform planned by Samara to enhance the efficiency of delivery of compulsory education in the Region will take several years to implement. The key element of Samara's program of school rationalization is the creation of school clusters in order to achieve larger class groups so as to benefit from economies of scale in education. Although small schools containing uneconomically small classes are common in rural Samara, the Education Administration notes that few rural schools are more than 25 kilometers away from the nearest town center, and most are much closer than this.

- In addition to efficiency and resource related reforms, Samara has also developed new approaches to other issues of education reform including voucher-based teacher retraining programs to introduce the element of choice for in-service training, a regional based textbook procurement program to ensure a choice of books in all school subjects and an increase in student-teacher ratios, from the present norm of $8: 1$ to at least $25: 1$ in the vocational education system.

\section{Novgorod Viliki}

Like many Regions of Russia, Novgorod Viliki is a recipient region and the attention of its Education Administration is focused on the low level of resource flows and on ways to augment the consolidated education budget of the Region so as to satisfy, at the very least, the minimum educational standards required under the Russian Constitution and under various federal laws. The Director of the Oblast Education Administration negotiates with his peers, the Regional Duma and the Governor in an effort to obtain more budget for education, while at the same time encouraging all raion heads of administration to recognize the importance of education for the development of their districts.

Novgorod's Director of Education supports the proposal of the Association of Education Administrators that federal subventions to the regions be increased so as to cover fully the costs of delivering the federal component of the education curriculum. The Regional Administration is further proposing that, if and when the Federal Government agrees to increased funding earmarked for education, these monies be channeled directly from Federal Government to institutional bank accounts via a new "treasury system." The idea is to avoid problem of diversion of education funds at oblast and raion levels.

Novgorod demonstrates the special problems encountered in many rural schools throughout Russia. In Novgorod, approximately $70 \%$ of schools and $50 \%$ of teachers are located in rural areas, whereas only $25 \%$ of students live in rural areas. As a result, teachers and facilities are relatively underutilized in rural areas of the Region. Whether teachers are teaching full loads or not, student-teacher ratios in most rural schools are much lower than in cities. In 1995, the average teacher-student ratio was $1: 8$. Teachers in rural areas receive $25 \%$ higher salaries than those teaching in urban areas. Most teachers with university education and better teaching qualifications do not want to live in rural areas. However, in spite of its resource problems, Novgorod is undertaking several programs of education reform, most notably in the area of vocational education.

\section{Promising Policy Options}

\section{Resource Mobilization and Efficiency}

Increased Autonomy for Schools. A central component of Russia's educational reform program will be to give schools more autonomy and greater financial accountability. A key recommendation of 
this report is that each school should have its own independent bank account with the right to receive and retain private funds and with the responsibility for budget management delegated to the school director, who would be permitted to transfer savings made under one budget heading to another. As part of this change, schools could be encouraged to introduce higher charges for secondary education classes and for the purchase and/or rental of textbooks, especially wherever parents desire greater choice and can afford to pay. In addition and where possible, education establishments should examine ways of increasing revenues by renting out property and increasing the role of private provision of services to education establishments. A high rate of return might be achieved in investments that improve school infrastructure to reduce the current high levels of expenditure on heat, electricity and water. However, to achieve equity, Government should ensure that no qualified student is denied access to education of the same quality because of the family's inability to pay. Targeted scholarships could be introduced to protect the poor.

School Financing Mechanisms. Given current inefficiencies in the mobilization and utilization of resources for education in Russia, a formula-based approach to funding education and training in Russia is a promising option. A demand-side "capitation" funding formula ("money follows students") allocates funds based on the number of pupils enrolled in each institution, with some differences to reflect factors known to affect per-pupil costs such as: (i) the level of education (with more allocated usually for upper levels); (ii) the type of school (more for vocational than for general); and (iii) the extent to which a school's location is urban or rural (since education tends to cost more in rural areas).

With money following pupils, schools will have an incentive to make full use of existing capacity. This would lead to considerable savings on overheads and corresponding falls in the unit costs of education. Giving school directors control over school budgets will make it sensible for directors to economize where possible, as these funds will be guaranteed to benefit the school directly. School directors will for the first time be in the position to make decisions about the relative value of different inputs.

The combination of per capita financing and school budget autonomy will make it harder for resources to be reallocated to other sectors and will make it clear how much each school should be receiving each year, and whether or not it has received it.

In addition, in order to ensure optimum use of the existing budget, the Federal Government might wish to provide incentives to those regions most willing to undertake systemic educational reforms. One suggestion would be for the overall equalization grant for eligible regions to be split into sectoral components, i.e., one for education, one for child benefits, and so forth. The corresponding components would be allocated to regions on a matching principle and through the Treasury system. The former will help to ensure that local governments spend some amounts of their own money for these purposes; the latter will provide some Federal control over what regions spend so as to ensure that minimally acceptable levels are maintained for education.

Class Size. The Bank understands that a recommendation to increase class sizes would provoke adverse reactions from some Russian stakeholders, who argue that relatively large classes of 25 pupils are the norm in large towns and cities in Russia, and that factors causing smaller classes in rural areas would be difficult, if not impossible, to address within the Russian context. However, the potential for savings from increases in student-teacher ratios could be dramatic and the cost of failing to initiate some staffing efficiency measures would ultimately be very high. To illustrate, an increase in average class size from 20 to 26 pupils decreases the teacher requirement by more than 20 percent. If teachers' salaries comprise about 40 percent of what the regions of Russia now spend on education, this would imply a saving of 8 percent that could be used to address teachers' salary arrears or to improve classroom equipment and the availability of textbooks and educational materials. Independent of the inefficiency of small classes at the 
present time, a reduction in the number of teachers is inevitable in the future as school cohorts fall owing to a 40 percent reduction in births between 1989 and 1996. To meet an apparent "shortage" of teachers, many Regions have hired retirees on a contractual basis. Such contracts should be phased out as a way to reduce the number of teachers.

Teachers' Pay and Working Conditions. A system of reforms affecting pay, working conditions and provision of both pre-service and in-service teacher training could be expected to yield significant savings and enhance the quality of education. This report recommends that a package of reforms be put in place which would balance the incentives of better training and timely payment of salaries with a change in the contractual basis of teachers' employment, whereby more teaching would be done per week in larger classes. In making this recommendation, the Bank research team is aware that this issue is complex and politically sensitive and probably cannot be addressed adequately in the current economic situation. Nevertheless, some first steps should be taken towards these reforms. One such step which would increase student teacher ratios (and thus the efficiency of the system) would be to avoid the danger of underutilized teacher time by training fewer, highly specialized teachers of one subject only and by introducing a policy of training teachers to teach more than one subject.

Merging of Educational Institutions. Another very sensitive issue is the need to merge educational institutions, to achieve economies of scale where there is an overlap in the missions of adjacent institutions, or where existing schools are too small to be economically viable. The scope for this strategy is probably greatest in relation to vocational education and in the case of small rural schools. Larger schools can afford better equipment, more pedagogical materials and a greater choice of subjects, all of which will ultimately benefit learning achievement. While the merging of rural schools has already been piloted in some regions of European Russia, this strategy may not be suitable for all regions, especially in the North and Far East, due to climatic or geographical factors. In remote areas, distance education and other applications of new teaching technologies may be an alternative approach to reduce costs and to improve the learning environment.

\section{Quality}

Improved teacher training and retraining programs that are flexible and market-relevant may be the most essential element in the reform of Russian education, since, without well-trained educators, the quality of the system will decline over time and new graduates will be unable to satisfy the requirements of the changing labor market. Increases in standard class sizes will have implications for how classes are taught and will necessitate the introduction of in service training in new methodologies of teaching and learning. Additional teachers of foreign languages and teachers who can teach more than one discipline are particularly needed.

The MGPE should take the lead in reforming the State Education Standard. This needs to reflect a more qualitative, less quantitative view of education and should also ensure that present registration and licensing procedures for educational institutions be continued and that accreditation procedures be made more transparent and streamlined. At regional and local levels, the aim should be to simplify and regionalize State Attestation services and eliminate excessive bureaucracy.

The introduction of a national system of student assessment will entail the transparent administration of tests with the correct mixture of practical, oral and written components (including, where appropriate, computer-administered tests to ensure fairness and access). Consideration should be given to a decentralized system, with cross-regional branches, each one covering a number of regions and each having sub-regional testing centers. 
The information needs of the various decision-makers at the federal and regional levels should be identified, and a set of basic indicators should be developed that will provide Russian policymakers with a baseline profile of the knowledge, skills and competencies of students. In order to continue the cooperation with OECD and with Goskomstat, MGPE should take steps to strengthen the capacity of the Education Statistical Unit.

\section{Market Linkages}

For primary vocational education (i.e., for the PTUs), the ongoing process of devolving responsibility for the operation of institutions to the regions should be accompanied by measures to facilitate greater institutional coordination and efficiency from the pooling of resources and from the involvement of employers and students in the design of programs. For second-level technical and professional education, governance of the system and the authority and relative spheres of influence of sectoral ministries (e.g., the Ministry of Health for medical education) and professional associations should be clarified and agreed.

Consideration should be given to making vocational training (including adult education, retraining and life-long learning, and the interface of training with the labor market) the joint responsibility of both MPGE and the Ministry of Labor, with public and private responsibilities clearly defined and agreed by both ministries.

Consideration should also be given to reform measures, including: (i) the development of a comprehensive strategy to reorient PTUs and eventually integrate them into the general secondary stream; (ii) delaying specialization until at least the final year of secondary education; (iii) de-linking schools from a single enterprise (wherever this still exists); and (iv) orienting course content to new technologyrelated subject matter and the inclusion in the curriculum of "introduction to the world of work" and career orientation modules.

Some technikums could be merged to create institutions relevant to regional labor markets while, at the same time, addressing individual student needs. Simultaneously, some of the special secondary schools could be merged with these new institutions, especially in localities dominated by only a few specializations. It may be feasible to create new structures that would incorporate the higher end of some of the technikums that have become or are in the process of becoming colleges.

\section{Equity and Access}

The introduction of measures to ensure equality of access and choice for those who cannot pay for education services should be a priority of MGPE. The creation of objective evaluation systems (sponsored by MGPE) will benefit those who are in danger of being squeezed from the education system, especially from the opportunity to attend a good secondary school or university, because of inability to pay. Reliable examinations administered to recognized norms will create more equitable access to higher level education. Publicly recognized certification will create more opportunities in the labor market for graduates of the vocational education system. In addition, regional governments might wish to create scholarship schemes in support of those educational services that attract high levels of private funds currently and are, therefore, liable to become inaccessible to those without the resources to pay. 


\section{Conclusion}

Given the strong tradition of education excellence in Russia, it is not surprising that there is a lag in making obvious to all what those inside the education system already see as a problem of serious and growing proportions. By the same token, if the system of education in Russia is allowed to collapse as a result of budget cuts and inefficient budget allocations, it will take a very long time to rebuild what used to be (and what some may now take for granted). An intended purpose of this study is to help Russian educators to bring the message of inadequate and misallocated resources to the ears of central government departments and external donor agencies, whose understanding and assistance will be needed to divert impending disaster in Russian education. 


\section{INTRODUCTION}

\section{BaCKGRound: EduCATION REForm IN THE RUSSIAN FEDERATION}

There has been vigorous public debate about the reform of the education system in Russia since the summer of 1997, when the Commission for Economic Reform (CER) of the Russian Federation (RF) requested the Ministry of General and Professional Education (MGPE) to prepare proposals for reducing unit costs in education and for making the outputs of the system more relevant to the needs of a changing market economy. Reform of education financing, including new systems to make fiscal flows to schools and to higher education institutions (HEIs) more transparent and the use of the funds more efficient, was an immediate objective of the CER. Education received no increase in the 1998 Federal Budget. In March 1998, the then Minister for Education presented his concept for reforming the system, ${ }^{2}$ and in May the Government announced plans to cut the number of employees throughout the public sector, including education workers. ${ }^{3}$ After the change of Government in September 1998, the new Minister of Education indicated his intention to continue with the reform proposals of the previous Government.

Under the proposed reform program, primary and secondary schools would be given greater responsibility for managing and augmenting their own budgets and would be held more accountable for the quality of the education services delivered. Reform measures, including capitation funding, would be piloted in selected regions in the medium term, with a view to introducing proven changes nationally as soon as possible thereafter. Fundamental and rapidly implemented fiscal and governance reform will exert pressure on local education administrators, schools principals, teachers, students and parents. About 70,000 schools could be affected if the reforms are introduced nationally.

\section{SCOPE OF STUDY}

This study was undertaken by the World Bank at the request of MGPE. A major purpose of the study was to identify key issues in pre-university education (general primary and secondary, as well as vocational secondary) in order to assist Government's efforts to articulate and implement its program of education reform. Given the realities of Russian education today, meaningful analysis of these issues needed to include analyses at the regional and sub-regional levels. An early draft of the report was produced in the form of a Policy Note and discussed with Government in June 1998. The findings of the study will also inform the future operational work of the World Bank in Russian education. The implied operational directions presented here are consistent with the Bank's Country Assistance Strategy (CAS), whereby the Bank will support Government's efforts to: (1) adjust the content of educational curricula to meet the needs of a market economy, (2) promote new financing mechanisms to encourage greater costeffectiveness and client responsiveness, and (3) clarify governance and managerial responsibilities. ${ }^{4}$

2 Minister Tichonov's address to the Collegium of the MGPE, March 31, 1998.

3 Draft Public Expenditures Reduction Program, Russian Federation, May 1998.

4 The last full CAS for the Russian Federation was discussed by the World Bank's Executive Directors on June 8 , 1997. The CAS update, discussed by the Board on December 22, 1998, highlights the increased need for assistance to the education 
Chapter $l$ of this report presents major issues in Russian education, identified through primary and secondary data analysis and in discussions with Russian educators, including during the study team's visits to Saratov, Samara and Novgorod Oblasts. Chapter 2 addresses differences across Russia and demonstrates growing inequalities in how funds are allocated and spent at regional and sub-regional levels, through an analysis of budgetary trends in the 89 regions. Chapter 3 lays out policy options, as presented to Government in June 1998 for the attention of policymakers. Detailed descriptions of the contrasting education situations and reform efforts in Samara and Novgorod, together with data tables and figures that demonstrate the developments in Russia's transition to a market-based education service system, are given in the annexes to this report.

\section{METHODOLOGY}

In December 1997, an initial visit was made to Saratov region, chosen because its leadership is implementing a program of educational reform. Data were collected from the regional and sub-regional offices on educational expenditures, student enrollments, the budgeting process, systems of management, budgetary transfers from the federal government, inter-raion budgetary transfers within the oblast, private sources of financing and non-public provision of education. Following that visit, a questionnaire was developed, and this was then used to collect information in seven additional oblasts so as to make generalizations about the nature, extent and outcome of decentralized financing of education in RF. A second and larger mission in March 1998 included visits to two of the seven oblasts, Samara and Novgorod, to explore in greater depth the questionnaire results and to conduct interviews with teachers, parents, education administrators and other professionals.

An analysis of data from all (89) regions was completed to identify broad patterns of education financing. This data gives a picture of how different areas of the country have fared during the transition, both in defending the share of budget going to education and in maintaining the quality of education services.

\section{ISSUES}

The education sector in Russia is one with a proud tradition. Most school-age children have access to school places, and nearly all adults in the population are literate. Under central planning, however, the education system operated without incentives for promoting accountability and efficiency. Moreover, early efforts at reform included the rapid decentralization of responsibilities for general education to the regions, in most cases without commensurate transfer of resources for the regions to maintain and operate this system satisfactorily. The worsening fiscal base, as well as confusion about roles and responsibilities at each level of government, have contributed to growing inefficiencies and poor articulation between the outputs of the education system and the needs of the emerging market economy. This unclear devolution of responsibility, while creating new opportunities for the system to become more responsive to local needs, is placing new burdens on administrators in all regions by asking them to fulfil roles for which they are certainly untrained and often lack the necessary funding. It is intended that schools should become autonomous and take responsibility for their own budgets. Yet, there has been no program to train administrators in financial management and there is often overlap and lack of clarity at sub-regional

government for important administrative functions. There is, in addition, growing concern that the quality of education services is being compromised by the shrinking resource base and by weak

sector at sub-national level: "If the crisis were to persist and further erode funding for basic services in health and education, Russia's human capital base would be at risk, diminishing the country's prospects for years, or even decades. Sub-national governments face the brunt..." 
institutional development that undermines the capacity to implement reform. On the positive side, however, decentralization may have increased parental choice and school autonomy.

Based on the analysis of data and visits to the education systems of Saratov, Samara and Novgorod, the study identifies four areas in Russia's education sector where there are major issues to be addressed: (1) resource mobilization and efficiency, (2) quality and output measurement, (3) market linkages, and (4) equity and access.

\section{Resource Mobilization and Efficiency}

\section{Inadequate Public Expenditure}

Fluctuating between 3.6 percent and 4.5 percent of GDP during the $1990 \mathrm{~s}$, public expenditure on education in Russia is low, in comparison with Russia itself during the 1970s, when it hovered around 5 percent, and also by international standards. France, the United Kingdom and the United States of America all spent about 5.5 percent on education in 1996. Since, on a per capita basis, national income in Russia is less than a tenth that of these countries (at current exchange rates), the absolute gap in spending on education is huge. Moreover, reflecting the decline in Russia's GDP per capita in current dollars from $\$ 3,220$ in 1991 to $\$ 2,410$ in 1996 , the Ministry of General and Professional Education (MGPE) estimates that public spending on education and training per student fell at a rate of between 5 and 10 percent per year in real terms over this period. Since the devaluation of the rouble in August 1998 the situation has, of course, worsened considerably. GDP per capita fell to $\$ 1,937$ in 1998, and a preliminary estimate puts education spending in 1998 at just 3 percent of GDP. A further steep decline in GDP is expected in 1999. Education's share of the total consolidated budget (the sum of federal, regional and sub-regional budgets) has risen from about 5 percent in the early 1990s to above 13 percent in 1997, comparable to public education spending in Germany and France (about 10 percent) and in the United State ( 14 per cent), and considerably more than Greece (6.9 percent) but this increase reflects a decline in spending on other budget items ( particularly subsidies) (see Annex B).

Partly in response to the fall in GDP and partly reflecting a policy of decentralization, the structure of public financing for education in Russia has undergone major changes. The sub-federal levels of government, both regional and sub-regional, have always played an important nominal role in the management and financing of compulsory education in Russia, and since reforms in 1992 this has corresponded to real control over and responsibility for most compulsory schooling. Compulsory education, like other functions of the regions, is supported (in the case of "receiving" regions) by federal transfers from central government to the regions. Federal transfers have fallen, however, during the $1990 \mathrm{~s}$-- both in real terms and relative to what the regions themselves spend. Furthermore, in most cases these transfers are not earmarked but take the form of general block grants which regional authorities can allocate as they see fit, and there is evidence that the education sector is not always given high priority. Indeed, even in the extraordinary circumstances in which transfers earmarked for education have been

$5 \quad$ The 89 regions, or "subjects of the Russian Federation," comprise 21 republics, 52 oblasts, 6 krais and 10 autonomous okrugs. Nine of the 10 akrugs are, in fact, however, subsidiary units of larger oblasts or krais, meaning that there are just 80 non-overlapping regions in Russia today. At the sub-regional level, there are currently 1,869 raions, plus 650 major cities that have their own sub-regional administrations (and are not administered as parts of larger raions). "Compulsory education" refers in Russia to elementary plus general secondary education. 
made, it appears that these have not fully reached their target. This has happened during crises over wage arrears, with transfers earmarked for education sector wages reallocated to other sectors.

The financing and management of "professional education" (which, by the Russian definition, includes higher education plus all vocational education and training) is traditionally the responsibility of the Federal Government. ${ }^{7}$ Fiscal difficulties have resulted, however, in reduced Federal Government financing of professional education, most especially at the low end of this system-- "first-level" vocational education, the PTUs. ${ }^{8}$ In fact, the Federal Government has announced plans to transfer management responsibility for the PTUs gradually to the regional governments. Four of the 89 subjects of the Russian Federation (including both Novgorod and Samara, which were visited as part of this study) have already requested and been granted this transfer of responsibility. They are now managing the PTUs within their borders. ${ }^{9}$ Other types of professional education remain at least the nominal responsibility of the Federal Government, but here too there are signs of fiscal abrogation. The salaries of university staff were not paid during the first several months of 1998. If this pattern repeats itself regularly, responsibility for the financing and, ultimately, the management of professional education can be expected to shift further from Federal Government to the regions in the years to come.

Financing for education has declined also as a by-product of the privatization of state-owned enterprises (SOEs) that has occurred as part of Russia's transition to a market economy. In Soviet times, the SOEs provided a variety of community-level social services for those working in these enterprises, as a form of non-monetary compensation. As an example, preschool (nursery and kindergarten) education was often operated by the SOEs and provided free-of-charge to the children of workers. PTUs (initial vocational education schools) were also the responsibility of the SOEs. Today, most preschool education has been handed over to municipal authorities. This increases the financial burden on the regions' consolidated budgets of providing educational services to regional populations. Municipal governments usually do charge fees for preschool education, up to the limit (20 percent of operating costs) allowed under federal law. While the fees represent only a fraction of the total cost of preschool education, they may impose a heavy burden on poor families, who are facing higher prices for other commodities as well, including higher charges for compulsory education. ${ }^{10}$

The proportion of children enrolled in nursery school and kindergartens is falling in most parts of the country -- partly in response to the increase in price, partly because more parents are out of jobs and now able to care for preschool-age children at home (Annex C). The combined effect of reduced preschool attendance on school-readiness when a child enters grade 1 has not been studied, but the

6 For instance, in December 1998/January 19992.5 billion roubles were transferred to regional budgets to pay off teachers' wage arrears, amid widespread threats of teacher strikes. The Altay Republic was one recipient region: its allocation was sufficient to pay all teachers one month's salary, but only 40 percent of this was in fact paid to teachers.

7 Education spending by the Federal Government represented about 3.5 percent of the federal budget in 1997, and 25 percent of the total consolidated budget for education in the same year.

8 Professional 'no-tekhnicheskiy uchrezhdeniya or nachal 'noye professional noye obrazovaniye.

9 For the time being, the Federal Government continues to provide some funding for the PTUs in these four oblasts, transferring the funds from the federal budget to the oblasts as "dotations" (the "English language" term used in Russia to denote budget transfers made to cover additional expenditures resulting from a transfer of responsibility from a higher level to a lower level of government).

10

Informal fees for compulsory education tend to be small, however, except in the case of elite schools such as the lyceums and gymnasiums which have grown up in many urban centers in recent times. Attendance at these schools, which often have close ties to near-by higher education institutions, is somewhat dependent on socio-economic status. Except in rare instances, poor families and families without a strong tradition of education achievement will send their children to regular compulsory schools, entry from which to higher education is much less certain than from the lyceums and gymnasiums. 
elimination of preschool classes probably outweighs the positive impact of increased parental inputs, at least in the case of very poor families. Some families appear unable to cope at all with the loss of income and other pressures of the economic transition, and the number of "social orphans" (children of destitute and/or criminally-involved parents) is rising in many parts of Russia. The high costs of running orphanages, where staff-to-child ratios tend to be much higher than in day schools for older children, as well as the costs of compensating families who are willing to serve as foster parents, are a further drain on local government budgets.

\section{Inefficient Use of Resources}

As total resources for education decline and as the burden, on federal, regional and sub-regional budgets, of providing educational services climbs ever higher, issues of the efficient use of resources in education loom large in Russia. To the casual observer, it may be difficult to understand that there are serious and growing problems in Russian education. Although enrollments rates at some levels have declined slightly, nearly all children attend general education, through to the final year (grade 11 ). ${ }^{11}$ In the best of Russian schools, learning achievement is on a par with the best found anywhere in the world.

Staffing tends to be generous in nearly all schools. Federal regulations, in fact, limit the freedom that regions have to raise student-teacher ratios in compulsory education beyond certain limits. There are federal laws, for example, that specify that no class should exceed 25 students in number. ${ }^{12}$ Some schools in some regions may, in practice, have class groups larger than 25 students, but those that do so are technically in violation of federal laws. Much more common than large classes, however, are classes, especially in rural areas, comprising fewer than 25 students. In two oblasts (Samara and Novgorod) visited in the course of the research for this study, the research team was told of class groups as small as 3-5 students. There is no reason to think that such anomalies are unique to these two oblasts and cannot be found throughout the rest of Russia, especially in more distant and sparsely populated rural regions.

The number of non-teaching staff tends to be quite high in Russian schools as well (see Annex C table 2). In part, this reflects the diseconomies of scale of running many small institutions, meaning that the fixed costs of administration (e.g., the salaries of school directors and other school administrators) are spread over too few students. In part, however, the large number of administrative and other nonteaching staff reflects a tradition whereby public institutions are expected to satisfy multiple social objectives. In the current worsening economic situation, it also appears that increasingly there is a difference between the number of non-teaching positions in schools and the actual number of employees. In some cases, a teacher may occupy more than one position and hence receive more than one salary. School principals turn a blind eye to this practice as it is the only way to retain teaching staff particularly those who can teach foreign languages and other "popular" disciplines.

In Russia, there has been an expansion of private financing of education (including fees, enterprise contributions and the lease of premises) which constitute a valuable adjunct to public expenditures. It is not possible to arrive at a figure for private investment in education and estimates for the amount of private financing going into the system vary widely between 0.5 to 1.5 percent of the total expenditures -

In $1996,110.2$ percent of appropriate-age children were enrolled in primary education, 92.6 percent in lower secondary, and 59.2 in upper secondary (see Annex $C$ table 2).

12 A teacher in regular service is paid for 18 class periods, even if conditions in the school result in fewer periods actually taught. On the other hand, schools may ask teachers to teach more than 18 class periods, but teachers are then paid for their over-time work, on a prorated basis (i.e., at an equivalent per-class rate). This teaching load is low by OECD standards -18 hours per week times 37 weeks per year, or 666 hours per year, as compared with the Netherlands, where the load is 1,000 hours per year, and France, where it is 923, and Ireland, where it is 915 (OECD, Education ai a Glance, 1997). 
most of it in the Higher Education system. At present, however, the rationale and system for charging fees are very haphazard. In relation to the handling of money, schools as a rule do not have their own bank accounts which, combined with the lack of autonomy and the lack of treasury execution of subnational budgets, reduces government's ability to control the ultimate utilization of budget funds as well as accountability of school administrators for the private funds mobilized. Further examples of the difficulties in introducing efficiency to the system is the current problem of utilities arrears where schools cannot pay for their heat or electricity and where the utilities companies, in turn, do not pay taxes equivalent to the shortfall from public institutions.

In short, legal factors and social considerations, as well as historical inertia not yet overcome in the brief period since Perestroika, combine to result in a mix of inputs in Russian education that is often far from optimal. The impact of such inefficiencies (which contracting budgets tend to compound and make worse) on education access and quality is perhaps just beginning to be felt. Given the strong tradition of education excellence in Russia, it is not surprising that there is a lag in making obvious to all what those inside the education system already see as a problem of serious and growing proportions. By the same token, if the system of education in Russia is allowed to collapse, under the weight of budget cuts and inefficient budget allocations, it will take a very long time to re-build what used to be (and what some may now take for granted). An intended purpose of this study is to help Russian educators to bring the message of inadequate and misallocated resources to the ears of central government departments and external donor agencies, whose understanding and assistance will be needed to divert impending disaster in Russian education.

\section{Quality and Output Measurement}

Fiscal stringency, rapid decentralization and, as a result, lack of clarity as to the roles and responsibilities of different levels of government have posed problems for education administrators and professionals as they try to maintain the level of education inputs and ensure the quality of education outputs. The decentralization of the Russian education system should lead to an increase in the role of stakeholders at community level and should devolve more autonomy ( particularly for budgets) to schools. MPGE has principal responsibility for ensuring educational quality. A more competency-based and individualized approach to learning wherein students are encouraged to abandon the rote learning of the past and to acquire useful and applicable knowledge in a student-centered classroom environment needs to be developed. New teacher training, testing, assessment, examinations and qualifications arrangements will be needed to reflect these developments.

\section{Teachers Status and Salaries}

The teaching profession has been particularly demoralized during the last five years by having their low salaries frequently paid in arrears while, at the same time, other job benefits are also disappearing. Salaries are so meager ${ }^{13}$ that they are an impediment to recruiting and retaining good teaching staff. Moreover, incentives for existing teachers and school directors to learn new pedagogical or management skills are minimal, and this in turn encourages the perpetuation of a rigid, hierarchical and inefficient system. The low salaries and low prestige attached to teaching are acting as a deterrent to those educated and trained as teachers (especially teachers of mathematics, sciences and English) from actually becoming

13 The average wage in education in 1996 was 551,000 rubles which was 70 percent of the average wage in the economy. This represents a slight increase from 1992 when the average wage in education was only 62 per cent of the national average wage. It should be noted that a large portion of teacher's wages have gone unpaid in recent years. (Annex 2). 
or remaining teachers. Given the delays in payment of salaries, it is difficult to imagine that all, or even most, of the existing teaching staff are ready to entertain any discussion of reform initiatives or changes in class sizes or teaching loads.

\section{Teacher Training and Retraining}

Current plans on the part of MGPE to devolve some aspects of education management, including responsibility for school-level budgets, to the school level will require increased management skills on the part of school directors in order for them to meet the demands both of financial control and of quality measurement. As schools gain greater autonomy, it will also be necessary to train School Directors in management, particularly in financial management, a need which will be shared by the education administration personnel in local government offices. In order to improve quality and initiate pedagogical and curricular reform, teachers will require new training in classroom management and in updated pedagogical methods. While some pedagogical universities offer very good initial training and are actively revising their curricula to include needed new courses, such as education psychology, there is nonetheless a concern about the quality of many teacher training institutions. Often, pedagogical universities permit entry to those with a relatively low level of educational attainment (a system of positive discrimination) so as to address a problem of rural schools that have difficulty in attracting and retaining teachers. Some Russian educators are also worried that retraining is not of the quality needed to preserve and renew professional standards and that it offers insufficient exposure to practical solutions to the problems of today's Russian society. There is a lack of access to new teaching materials, equipment, visual aids and information about new teaching methodologies. These constraints are further compounded by the rigidity of some older teachers to deal with the inevitable changes in their classrooms.

\section{Education Standards and Curriculum Reform}

Education standards are expected to address the requirements of a more decentralized education system by ensuring the equivalence of qualifications and facilitating the movement of individuals from one part of RF to another, while at the same time preserving the ideals of a "common education space." 4 Many courses taught in Russian schools do not yet encourage problem-solving, innovative thinking and creativity in the classroom. Core education programs need to be modernized and work has been ongoing since 1992 to develop minimum standards and to develop assessment and testing systems, as well as to reform accreditation and quality evaluation to meet the needs of the market and modern life. However, as of now, standards are still defined as inputs to the learning process rather than as student outcomes. Moreover, there is no mechanism by which MGPE can monitor and evaluate the quality of education programs throughout Russia. At Regional level, local authorities are unable to deliver evaluations of school quality and management owing to a lack of capacity.

\section{Testing and Certification}

Diversified and decentralized education systems require reliable forms of "outcome" measurement. This places an additional burden on MGPE, which is responsible for the quality of the education system without having at its disposal an objective and fair system of student assessment or one that ensures comparability of results across ethnically and geographically disparate regions. Historically, Russian pupils were probably over-tested but under-evaluated, and the system relied on teacher judgment with little possibility of independent evaluation. All students have the right to be evaluated objectively,

14 "Common educational space" is a term used in Russia to denote an equivalence of educational experience and qualifications in each of the 89 regions. 
and the public must have trust in the evaluation system. However, there is no trusted national service with the know-how and technical capacity to design, coordinate, administer and deliver the hundreds of multi-subject national examinations needed to address the national equivalency issue. Nationally recognized certification is critically important for those leaving the vocational education system. Moreover, in the absence of reliable assessment for school leavers, higher education institutions are obliged to organize their own entrance examinations, which consume scarce financial resources and raise questions about objectivity and fairness.

\section{Availability of Textbooks and Teaching Materials}

There is still a shortage of modern school textbooks and learning aids in certain key subject areas, such as civics, history, economics and languages. Teachers' manuals and other information for teachers facing new challenges in the classroom are lacking in many schools. The shortage is particularly acute for vocational education which needs new materials to reflect market needs.

\section{Absence of Accurate and Timely Education Statistics}

Russia lacks an accurate, easily accessible database from which policy makers or educational managers can assemble information about student numbers, unit costs and achievement levels. To date, there is little understanding that such data has added value for policy makers. In order for these data to become a useful instrument in the policy debate on Russian education, further processing and synthesizing in the form of education indicators would be needed.

\section{Market Linkages}

Neither general secondary education nor, especially, vocational education is, as yet, well equipped to respond to market signals and to reflect the rapidly changing conditions in Russia today. Vocational education institutions have had particular difficulty in adapting to the changing social and economic environment, and many are still not oriented towards current labor market needs. In the past, the vocational education system was fragmented, with a large number of sectoral ministries directly overseeing the operation of vocational education institutions. This made it difficult for individual institutions to share resources or to respond quickly to changing market conditions. Until recently, vocational schools trained their students for specific jobs rather than teaching them a set of skills that could be utilized in a variety of occupations across a number of fields. ${ }^{16}$

The overall effect has been to create a system of vocational education with little coherence and vision and lacking institutional coordination. There is not much standardization across institutions and

15 Reactions from Russian educators and policymakers to an earlier version of this study emphasize the change that has occurred in the vocational education system since 1990 and suggest that some of the conclusions in the report on this subject are no longer valid. It is worth noting that the authors of the comments are mostly Moscow-based and that the situation in Moscow and other parts of Western Russia is, to some extent, more flexible and labor market-responsive. In other parts of RF, the labor market is less vibrant, and there has been less significant change in the system of vocational education.

16. Approximately 40 percent of students enter a vocational training institution after completing the basic cycle at age 14 , and another 25 percent enter a PTU or technikum after completing general secondary school at age 17 . There are approximately 4,100 primary vocational institutions (PTUs) in Russia. For the most part, they are located in the Western part of the country. These institutions service 1.6 million students, 80 percent of whom receive student aid in the form of free lunches and uniforms. The secondary vocational education system includes 2,670 institutions (technikums) serving approximately two million students. 
remarkably little quality control. At the regional and municipal levels, there is wide interpretation of federal laws on education; regional and municipal authorities may be ignorant of the new laws, or doubt their enforceability. Furthermore, the need to earn revenue has resulted in the introduction of additional specializations with very little attention given to quality, institutional focus or federal standards.

Some steps have been taken to restructure and reform the system of vocational education, most especially in the four regions where management responsibility has been shifted from the Federal Government (see above). Some regions have taken the initiative to integrate and restructure vocational institutions, and new Federal guidelines reduce the number of vocational specializations. ${ }^{17}$

However, much remains to be done. Vocational school managers and instructors will be required to undertake quite fundamental change in order to achieve some of the reforms needed to make the vocational education system truly market relevant. It is difficult to imagine that all, or even many, of current staff are ready for these initiatives and special training interventions will be required. Other priority areas for reform include the specific problem concerning teaching materials for the vocational system. All school and college staff interviewed stressed that they needed new textbooks and good teaching materials for vocational education reflecting updated market conditions. In the area of assessment and certification, vocational schools also require special attention. School directors and administration personnel perceive that better and reciprocal qualifications are needed to address employers' concerns and labor mobility. Changes in the labor market will require new forms of certification for students who need to convince employers of their skills.

There is conflicting evidence about the employability of PTU graduates. Analyses cited in some sources ${ }^{18}$ suggest that graduates of first-level vocational education continue to do better in the job market than those coming out of the secondary general school system. However, anecdotal evidence contradicts this, suggesting that employers are reluctant to hire new graduates of PTUs, as they prefer more trainable workers with general educational background. It is possible that this discrepancy is explained by the slowly reforming labor market, in which the jobs obtained by graduates of the first level vocational system continue to be in traditional areas that have not yet adjusted to the transition. In any case, as the vocational education system reforms, higher quality courses and widely recognized certificates will be a necessary part of the reform. It is also essential that owners of established and emerging new businesses be consulted, as far as this is practical, and that their views be reflected in vocational course content and organization.

A radical systemic reform of the vocational education system is needed, and the ongoing process of decentralization points to regional, rather than federal, solutions as the most appropriate. Given that the PTUs, in addition to their educational function, have a social role, which is to keep otherwise disaffected young people in school, it is doubly important that a comprehensive restructuring strategy be developed and that the reform not be conducted in ad hoc fashion.

17 The number of vocational specializations was approximately 1,250 , as compared with only 440 in Germany (IMF et al. 1991:168). In April 1994, the Russian Government reduced the number of specializations to 257, and there are plans to reduce this number further to something in the range of 80 to 100 (Bolotov et al. 1995:63). The content of PTU instruction is also being reformed. National educational standards for 113 of the 257 professions have been approved and implemented. New legislation to define the framework and content of secondary vocational education is in the process of being adopted, including provision for regional and local elements of the curriculum to bring these in line with local labor market conditions.

18 Education and Production in the Russian Federation: What are the lessons? Castro et al. Paris: IIEP, 1997. The OECDCCET Labor Market Data Base (1996) gives an unemployment rate of 11.5 percent for secondary school leavers and 8.5 percent for graduates of vocational education. 


\section{Equity and Access}

The historical strength of Russian education was its commitment to equity and access, regardless of ethnic background, gender or geographical location. This principle enjoyed broad popular support and, even if in practice it might sometimes be breached locally, it was nonetheless an ideal that united the population. However, there is now a concern that the emphasis on educational decentralization and diversity is creating increased inequality and contributing to a narrowing of educational choice and opportunities.

The worsening financial situation is having adverse effects on the opportunity afforded to intellectually competent but poor students to stay in school or to benefit from the courses that would lead to a better lifelong situation. Many education institutions in Russia now seem to have abandoned the former practice of attempting (at least in theory) to provide these students with scholarships, which now (to the extent that there is still any money for scholarships) may be given to those financially better-off. In secondary education, the ability to pay often influences admission to extra courses and, in some cases, access to the school itself. The distortion of giving preference to those with financial resources, to the potential detriment of the less well-off, if allowed to continue, will make the education system quite inequitable.

Early specialization and the streaming of students in the secondary system have equity implications, because poor students and "late bloomers" are often sidelined and not given the kind of education that will equip them to function in the market economy. There are numerous examples of secondary school elitism, where special linkages between particular universities and feeder schools are cultivated from grade 10 onwards (and sometimes even earlier than grade 10). Some universities draw as much as 70 percent of their student body from high performers in these feeder schools. Significant federal and private resources are devoted to the preparation and training of these pupils. With the cooperation of certain universities, these exclusive schools have been transformed into gymnasia and lyceums where university staff take an active role and, in some cases, give special tutorials or otherwise groom selected pupils for special scholastic competitions and for university entry. Winners of the School Olympiads and other competitions are often admitted into the university without having to sit examinations. This system is open to abuse. Parents often lobby to gain access for their children through donations of expensive items of equipment such as computers; university teachers can often increase their earnings substantially by teaching college preparatory courses tailored precisely to the entrance requirements of their universities -- examinations which, as often as not, are set by these same teachers.

As has been discussed, the existing system of education finance does not have explicit mechanisms for compensatory funding of educational spending and redistribution of budget revenues between regions with different fiscal bases. Consequently, there is the danger that over-concentration on fiscal efficiency will not only affect choice and access but also contribute to inter-regional differences. In addition, the application of rigid funding formulae (if implemented) could have inequitable consequences for the distribution of funds within a region. Evidence from the study team's visits to Samara and Novgorod in March 1998 confirms the difficult choice facing regional administrators who may have to choose between heating schools during cold winter months and paying teachers' salaries on time; or raion administrators, between keeping hospitals open and paying teachers. In these conditions, it seems inevitable that the necessity for frugal budget management inside a less well-off region will undermine support for, inter alia, rural schools, special schools, minority pupils and those coming from "at risk" families, unless a practical "weighting factor" for special needs can be developed. 


\section{NATIONAL AND REGIONAL TRENDS IN THE DEMAND AND SUPPLY OF EDUCATIONAL SERVICES}

\section{INTRODUCTION}

During the Soviet period, the fiscal autonomy of regional and sub-regional levels of government within Russia was quite limited. Norms were imposed from Moscow as to the levels of expenditure on most social and other programs. Any excess revenues, over and above those needed to satisfy these federal norms, were passed along to the next level of government to be distributed according to regional norms. In the area of education, the goal was to provide all students, regardless of where they lived in Russia, with the same educational experience. While not fully achieved, this goal of a "common educational space" was government policy and it enjoyed wide popular support. Since Russia became independent in 1992, it has embarked on a somewhat chaotic process of decentralization giving regions more control over their own resources, a greatly widened set of expenditure responsibilities and more autonomy regarding education and other types of social expenditures.

Russia's transition to a market economy has led to a greater divergence of incomes across regions and, within each region, across households and individuals. A few of Russia's regions have been able to capitalize on their resource endowments, location or other factors to increase per capital income relative to the rest. Those regions with high per capita incomes have been able to spend more on education and other social areas. While higher levels of expenditure do not necessarily translate into higher educational outcomes, ${ }^{19}$ nevertheless, Russia's poorest regions are now struggling to maintain the basic requirements for high learning achievement in schools.

There have been several attempts since 1992 to create a workable fiscal equalization mechanism that would help to preserve the goal of a common educational space across the regions of Russia, ${ }^{20}$ as well as across lower-level units (rayon's) within regions, but these attempts have proven generally quite ineffective because of the many regions eligible to receive transfers and the relatively small amount of money available for redistribution. Typically, only about 8-12 of the 89 regions have qualified as "donor" regions. All the others are eligible to receive subsidies. With Russia's lagging tax collection, a vicious cycle of wage arrears and other problems has developed. This in turn has meant that the regions have had to rely more on their own resources, and most are unable to meet the costs of basic educational needs.

19 There are myriad other mitigating factors such as student-teacher ratios, physical education infrastructure and the quality of teachers and education administrators that affect the quality of education services delivered across regions.

20 There are 89 regions or "subjects of the federation" in Russia today. This administrative level is usually referred to as the "oblast level," even though, technically, some of the 89 are not oblasts. The subjects of the federation are often grouped into 11 larger "economic regions". The economic regions are a remnant of Soviet central planning, but these divisions are still sometimes used for presentation purposes in statistical and other publications. Kaliningrad Oblast, separated from the rest of the Russian Federation by the Baltic states, is not part of any of the 11 economic regions. Kaliningrad data are not included, therefore, in any of the sub-totals reported for economic regions in the tables in this chapter, although Kalingrad data are included in the national totals. 
At the same time, there have been demographic trends in Russia that have impacted dramatically upon the educational system. The first has been the decline in the birth rate, starting in the late $1980 \mathrm{~s}$ and now beginning to be felt in schools. The second has been the two large migration streams, the one from the periphery regions to the central regions of Russia and the other from the non-Russian FSU states back into Russia.

Not all of the effects of decentralization on education have been negative ones. When done properly, moving decision-making down to lower levels of government puts decision-makers closer to the clients, in this case, teachers, parents and students, and results in more efficient funding allocations. Decentralized decision-making in Russia should have paved the way for regional differences and innovation, whereas the emphasis in the past was on standardization across the vast expanse of the country. With spending on education in Russia now severely constrained, the hope is that some reformminded regions will devise and test innovative ways that increase the efficiency of education spending and produce good models that can be replicated later in other parts of the country. There already seems to be some evidence of this is in the case of Russia. There is a significant correlation between a high local share of total regional revenues and a larger share of regional expenditures on education. ${ }^{21}$ This seems to support the notion that lower levels of government are more responsive to the social needs of the population and that decentralization brings about a more efficient allocation of resources.

\section{DEMOGRAPHIC TRENDS AND THEIR IMPACT ON EDUCATION}

Familiarity with recent demographic trends in Russia, in the country as a whole and also at the regional level, is important to understanding changes that have occurred in education during the transition period. Declines in the birth rate, increases in the death rate and migration movements both within Russia and between Russia and the other FSU states, have had and will, for the foreseeable future, continue to have an impact on the demand for education in the regions -- apart from any impact of the economic transition or of the fiscal decentralization now taking place. Some of the changes in key indicators for education, such as the student-teacher ratio, can be explained almost entirely in demographic terms. The discussion that follows gives an overview of changes in Russia's total population, in the age composition of the population (especially changes in size of the school-age population relative to the total) and in the distribution of the population across regions. ${ }^{22}$ The two main components of population change (natural increase and migration) are analyzed separately since they affect education differently.

Russia's population peaked in 1992 when it reached 148.7 million. Since that year, deaths have exceeded births, putting Russia in the company of a small group of countries (about a dozen in the world) that have negative natural rates of population growth. Births in Russia peaked in 1987 when 2.5 million children were born. Since then, the annual number of births has fallen dramatically, by almost a half, reaching 1.3 million in 1996. This implies smaller cohorts of school-age children every year and, assuming nothing else changes, declining demand for places in schools. The trend can be seen graphically in the age-sex pyramid of the population (figure 2.1). Beginning with the children born in 1987, each of the next ten cohorts is smaller than the one before it. Because of initial effects of the market economy, including lower and less certain family incomes, the birth rate is expected to remain low in Russia for the foreseeable future. Under differing projection scenarios, the number of children born will either fall further (to 1.2 million) or rise moderately (to 1.6 million) by the year 2010 .

\footnotetext{
21 Lev Freinkman and Plamen Yossifov, "Decentralization in regional fiscal systems in Russia: trends and links to economic performance", The World Bank, draft September 1998.

22 This discussion of demographic trends in Russia is based in part on Heleniak, Timothy, "Internal Migration in Russia During Economic Transition," Post-Soviet Geography and Economics, no. 2, 1997, pp. 81-104.
} 


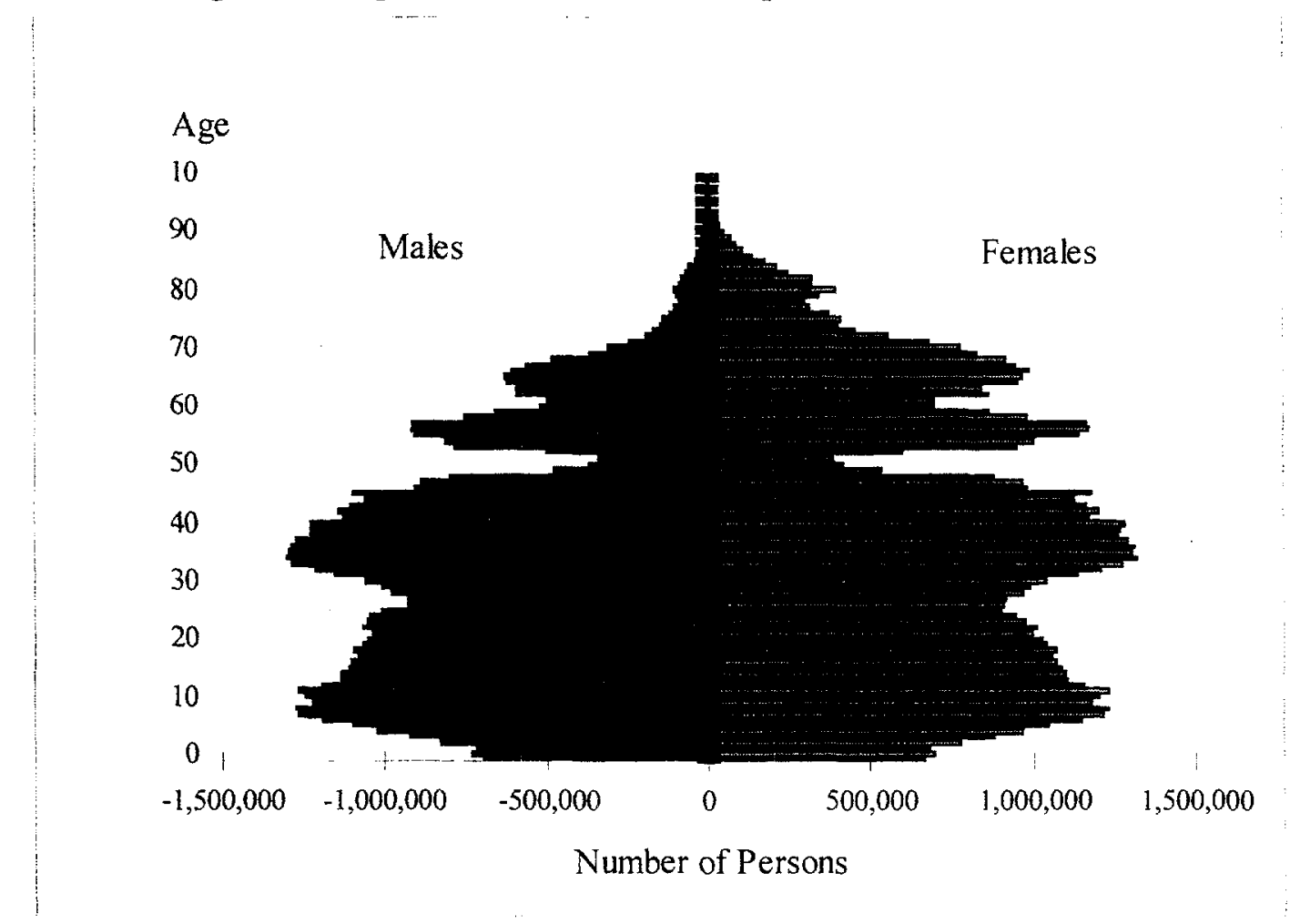

Source: Goskomstat Rossii, Chislennost' naseleniya Rossiyskoy Federatsii po polu i vozratsu na 1 yanvarya 1997 goda: Statisticheskiy byulleten', Moscow, 1997.

For most of the Soviet Union period, the predominant migration pattern affecting Russia was from Russia to other parts of the USSR. This trend reversed itself in about 1975. Migration into Russia from other FSU states increased during the 1980s and early 1990s, peaking in 1994, when over one million migrants, the majority of these Russians or Russian speakers, entered the Russian Federation. Return migration has slowed since then. Net migration into Russia in 1996 was 349,500 , as compared with 893,100 in 1994. Today (1998), the total population of Russia is about 147.4 million, approximately the same as in 1989 (the date of the last population census), and a million and a half fewer than in 1992 (when population peaked). Over the past decade, the excess of deaths over births has been offset almost exactly by net migration into the country.

The two components of population change (declining birth rates and increasing in-migration rates) affect the age structure of the population differently. The reduction in births reduces the number of children entering the education system six to seven years later. On the other hand, a majority of the migrants who have entered Russia are young, in their twenties and thirties, and their children add to the numbers entering the schools, thereby offsetting the negative effect of fewer births, but only partially. Table 1 shows that the number of school-age children has declined by 3.6 million over the past 8 years and is expected to decline by another 7.8 million by the year 2010 , from 24.4 to 21.9 percent of the population. Thus, all else equal, the demand for education services in Russia is shrinking as the negative effect of the declining birth rate outweighs the positive effect of in-migration. 
Table 2.1 Age Composition of Russia, 1989-2010 (thousands)

\begin{tabular}{|c|c|c|c|c|c|c|}
\hline & \multicolumn{2}{|c|}{1989} & \multicolumn{2}{|c|}{1997} & \multicolumn{2}{|c|}{2010} \\
\hline & Total & Percent & Total & Percent & Total & Percent \\
\hline Total & 147,022 & 100.0 & 147,137 & 100.0 & 139,300 & 100.0 \\
\hline Below working age & 35,995 & 24.5 & 32,300 & 22.0 & 24,700 & 17.7 \\
\hline Working age & 83,746 & 57.0 & 84,338 & 57.3 & 84,800 & 60.9 \\
\hline Above working age & 27,196 & 18.5 & 30,500 & 20.7 & 29,800 & 21.4 \\
\hline
\end{tabular}

Note: The "working age" is 16 to 54 for women and 16 to 59 for men.

Source: Goskomstat Rossii.

More interesting than the trend in the country as a whole are the regional trends in the number of school-age children. Over the period from 1989 to 1997, about half the oblast-level units in Russia (44 of 89 ) had population declines. The causes of these declines varied in different parts of the country. The population declines in the peripheral areas of the North (e.g., Siberia and Far East) were the result of net out-migration. The declines in the more densely populated western sections of the country were the result of aging populations and low birth rates. Internally within Russia, there has been a similar reversal of decades-long migration patterns in response to the economic transition. Most of the internal migration within Russia during the days of the Soviet Union was from the European core to the northern and eastern periphery. Eight of the eleven economic regions reversed the direction of net migration between the 1980 s and 1990s. The Volga-Vyatka, Volga, Urals and Central Chernozem regions, which had been areas of net out-migration, have all become areas of net in-migration. The opposite occurred in the case of four peripheral economic regions (namely, the North, East Siberia, West Siberia and Far East), which had been areas of net in-migration but have become areas of net out-migration.

The importance of these different trends for education is that those areas that have lost population have lost students in disproportionate numbers, while regions gaining population have received proportionately more school-age children than adults (see figure 2.2). There were only five oblast-level units where there was an increase in the absolute student population between 1989 and 1997. One was Dagestan, which has traditionally had one of the highest birth rates in Russia. Two others were the Krasnodar and Stavropol Krays in the North Caucasus, both major recipients of migrants from the nonRussian FSU states as well as from other parts of Russia. In both these regions, however, the increases were negligible.

Approximately a third of the 89 subjects of the federation experienced declines in the school-age population smaller than 10 percent (see figure 2.3). These were mainly regions in central Russia that have older age structures. Another third of the regions had declines of school-age children of between 10 and 20 percent. Many of these are located in Siberia. Ten regions, most of these in the Northern or Far East periphery, had declines of school-age populations of over 20 percent. These were all regions that experienced massive out-migration over this period. In nearly all cases, the decline in the school-age population was much greater than the overall population decline (because of the selective age structure of migration described above). As examined in more detail elsewhere in the report, these declines in student numbers were seldom accompanied by commensurate declines in teacher numbers. The end result, in other words, has been a decline in student-teacher ratios which, all else equal, implies an increase in education unit costs. 
Figure 2.2 School-Age Population as a Share of the Total Population by Economic Region, 1989 and 1997 (15 years and younger)

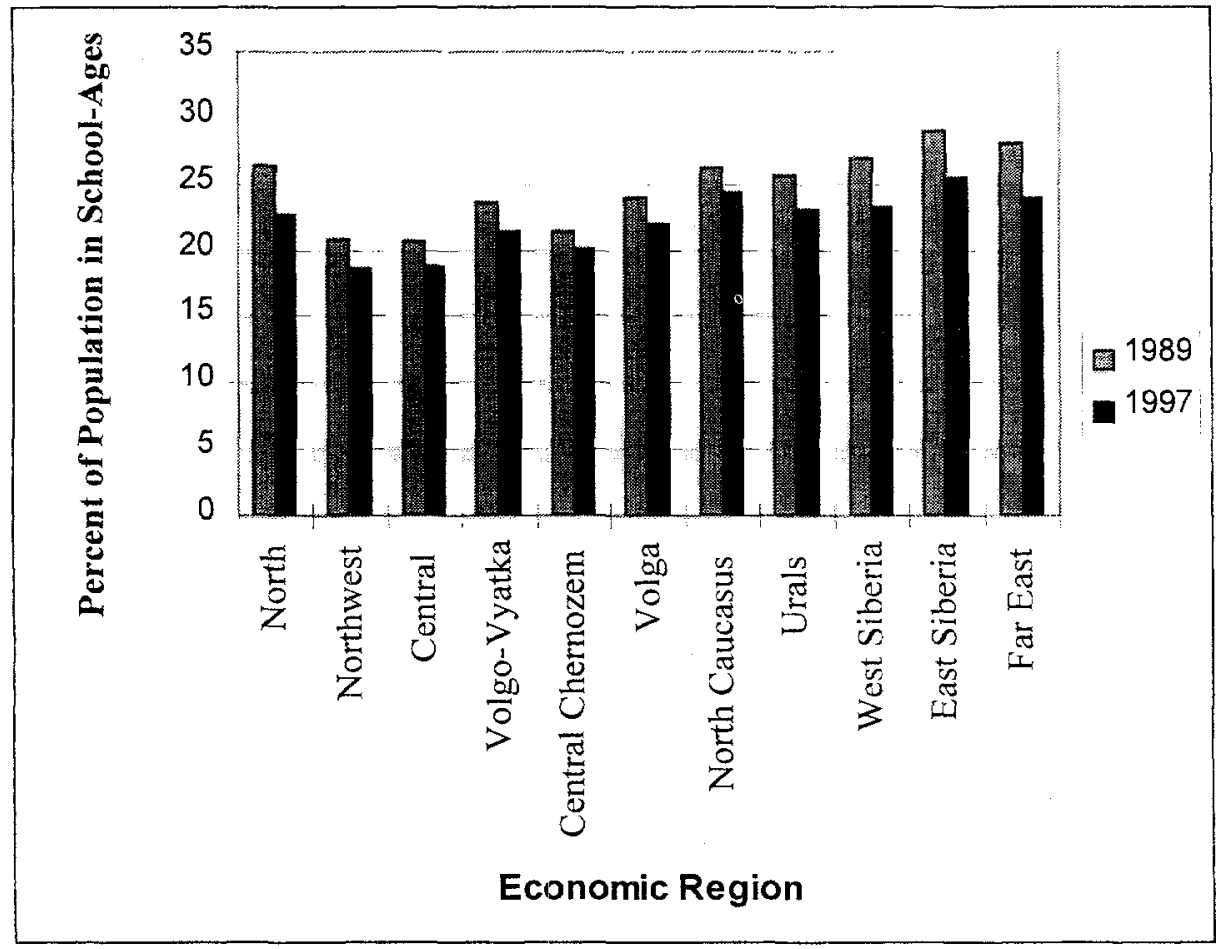

Source: 1989: Goskomstat Rossii, Kratkay sotsial'no-demograficheskaya kharakteristika naseleniya RSFSR do dannym Vsesoyuznoy perepisi naseleniya 1989 godu Chast' 1, 1991, pp. 66-83. 1997: Goskomstat Rossii, Demograficheskiy yezhegodnik Rossii: Statisticheskiy sbornik, 1997, pp. 44-46

\section{TRENDS IN EDUCATIONAL ATTAINMENT}

As discussed in Chapter 1, an achievement of the Russian educational system has been a population with high levels of educational attainment. Figure 2.5 shows how educational levels have increased even over the last 15 years. The share of the adult population (ages 15 and older) with higher education degrees nearly doubled over this period, rising from 77 per thousand in 1979 to 133 per thousand in 1994. Those who had finished technikum courses increased from 127 to 219 per thousand over the same period, and those who had completed general secondary, from 204 to 285 . The corollary of these changes is that those with incomplete secondary or just primary education declined quite dramatically. In part, this trend is attributable to the aging of the Russian population -- younger, moreeducated cohorts are replacing older, less-educated ones. As with many aspects of life in Russia, there are important regional variations among educational levels, including interesting trends as to how regional rankings have changed during the transition period. One shortfall of Russia's education system is the absence of objective measures of learning achievement at the individual, school and school district levels. Educational attainment is quite a poor, surrogate indicator of learning achievement, measuring quantitative achievement only and often hiding differences across students or changes over time in qualitative achievement. 
Figure 2.3 Change in the School-Age Population by Region, 1989-1997

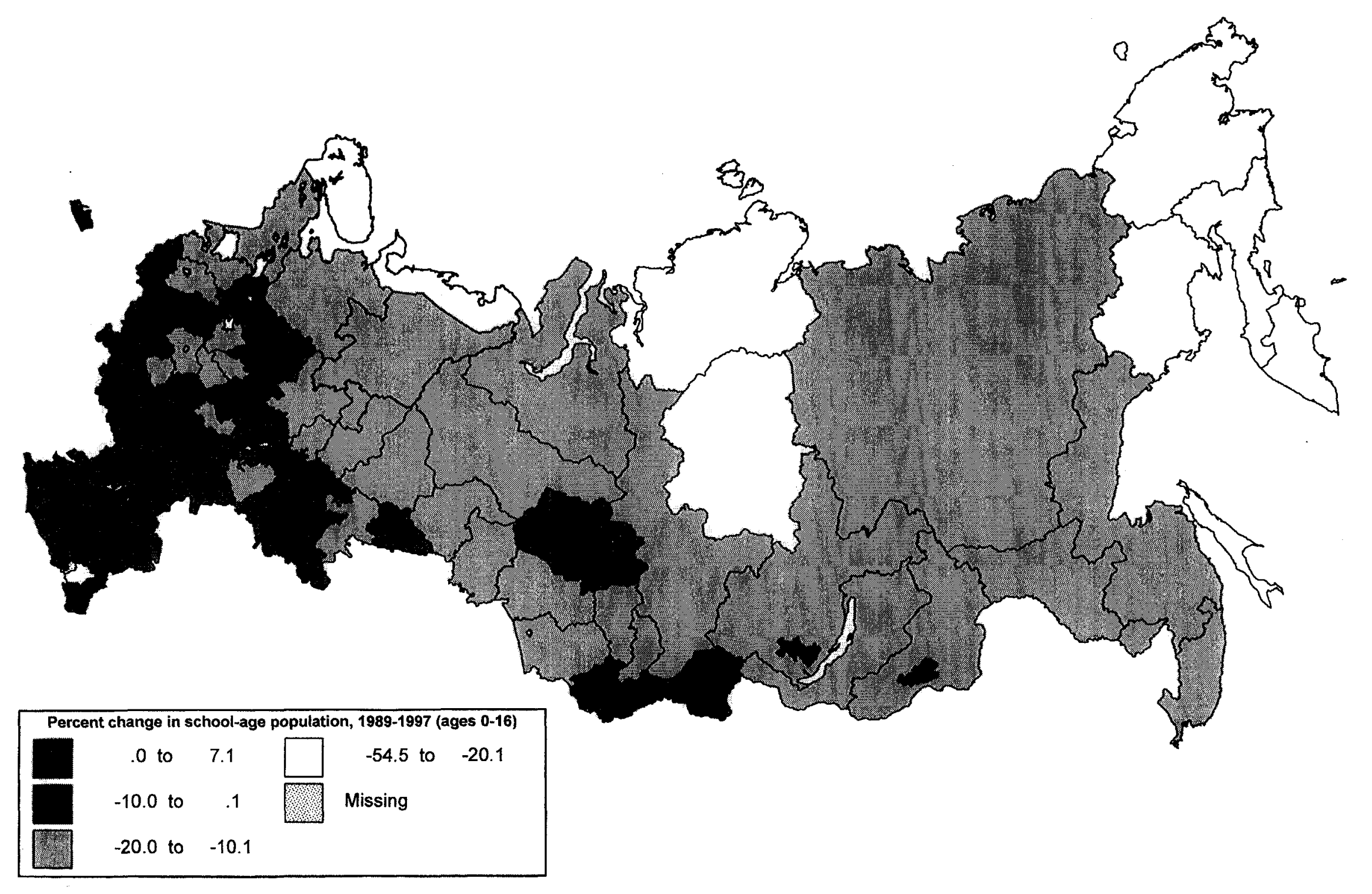


Figure 2.4 Level of Education of the Population of Russia, 1979, 1989 and 1994

(per 1,000 persons 15 and older)

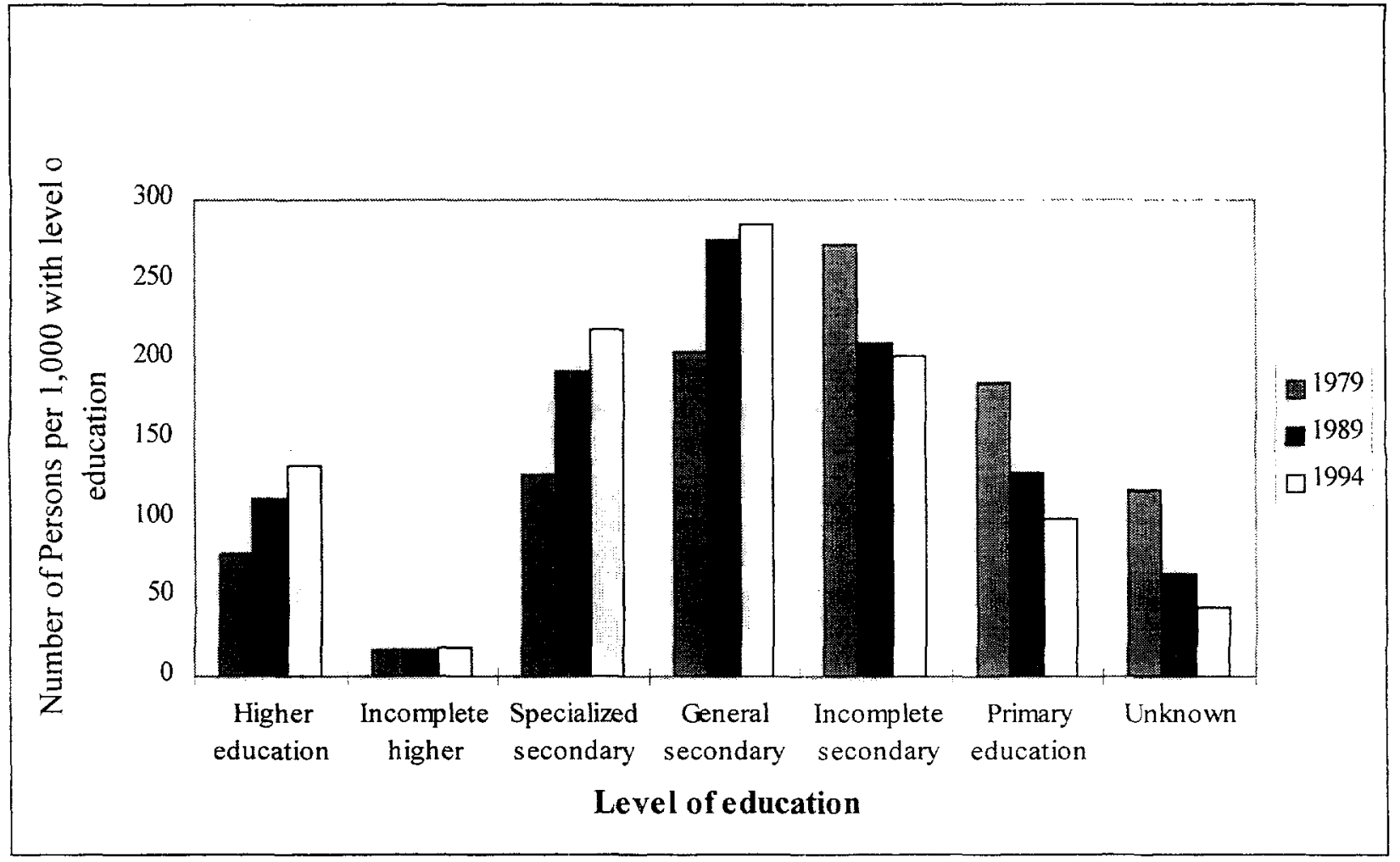

Source: 1979: Goskomstat Rossii, 1979 Population census results, 1989: 1989 USSR Population Census, CD-ROM. 1994: Goskomstat Rossii, Obrazovaniye naseleniya Rossii (po dannym mikroperepisi naseleniya $1994 \mathrm{~g} ., 1995$.

In 1989, many regions on the periphery, including Murmansk in the North and Magadan, Chukotka and Kamchatka in the Far East, had significantly higher shares of their populations who had completed higher education than the national average (figure 2.5). Propensity to migrate is associated with higher education and many of these regions outside of central Russia are populated with newcomers who were educated elsewhere and who moved to the outlying regions in search of high paying jobs. An additional explanation is that some of these outlying regions (e.g., Murmansk and Kamchatka) were closed in the past for military reasons, and even Russian citizens were obliged to receive permission to travel and live there. Normally, permission was granted only to highly educated workers. Most of the peripheral areas of the North, the Far East and Siberia also had higher than average shares of their populations possessing specialized secondary educations. This reflected the industrial emphasis in those regions as well as the fact that they tended to have younger populations (and few elderly people, who generally have completed fewer years of education).

Not surprisingly, the two federal cities of Moscow and St. Petersburg (as well as Moscow oblast) had by far the most highly educated populations in the country in 1989, with over one in five persons (ages 15 and older) in St. Petersburg and over a quarter of those in Moscow city having completed higher education. Many people from outside these two cities went there to study, because of the good reputations of the educational institutions in these places, and later found employment there and did not return home. One equity issue that has arisen during the transition period is the declining access to Moscow State University and other highly regarded universities and institutes in Moscow and St. Petersburg because of the escalating costs of travel and living away from home. Prospective students in the regions can no longer afford to take the entrance exams or to pay room and board in Moscow and St. Petersburg. 
Between 1989 and 1994 in Russia as a whole, there was an increase of 20 per thousand adults who had completed higher education and an increase of 27 per thousand who had completed specialized secondary education. During the transition period, from 1989 to 1994, many outlying regions, such as Murmansk in the North and several regions in the Far East, had declines in the shares of their populations who had completed higher education or specialized secondary education. This was the result of the large out-migration of educated people from these places, who moved to Moscow, St. Petersburg, Saratov and other cities in Russia's European core, which had much higher than average increases over this period in the number of adults with high levels of education (figure 2.6).

\section{TRENDS IN EdUCATIONAL SERVICES}

This section examines changes in various aspects of educational provision in Russia during the transition period. The discussion will cover the number of institutions, students and teachers at each level of the education system, followed by an overview of regional differences in the dependence on multiple school shifts. The section concludes with a discussion of teachers salaries in the regions.

\section{Pre-School Education}

Russia has long had an extensive system of pre-schools, although enrollments at this level have contracted somewhat during the transition period owing to both supply-and demand-side factors. At the end of the Soviet period, two-thirds of all one-to-six year old children in Russia were in pre-school. This was the highest rate of participation among the FSU states. One of the reasons for pre-school provision was to promote female employment. Thus, nurseries or "creches" were often located on the premise of the state-owned enterprises. For the youngest children, from infancy to age 3, the function of pre-school was primarily custodial. For children above the age of 3, learning was also emphasized. Pre-school services included immunization, health checkups and nutrition as well as socialization and formal learning. Nearly all of these services were provided to working families free-of-charge, or at very low cost. 


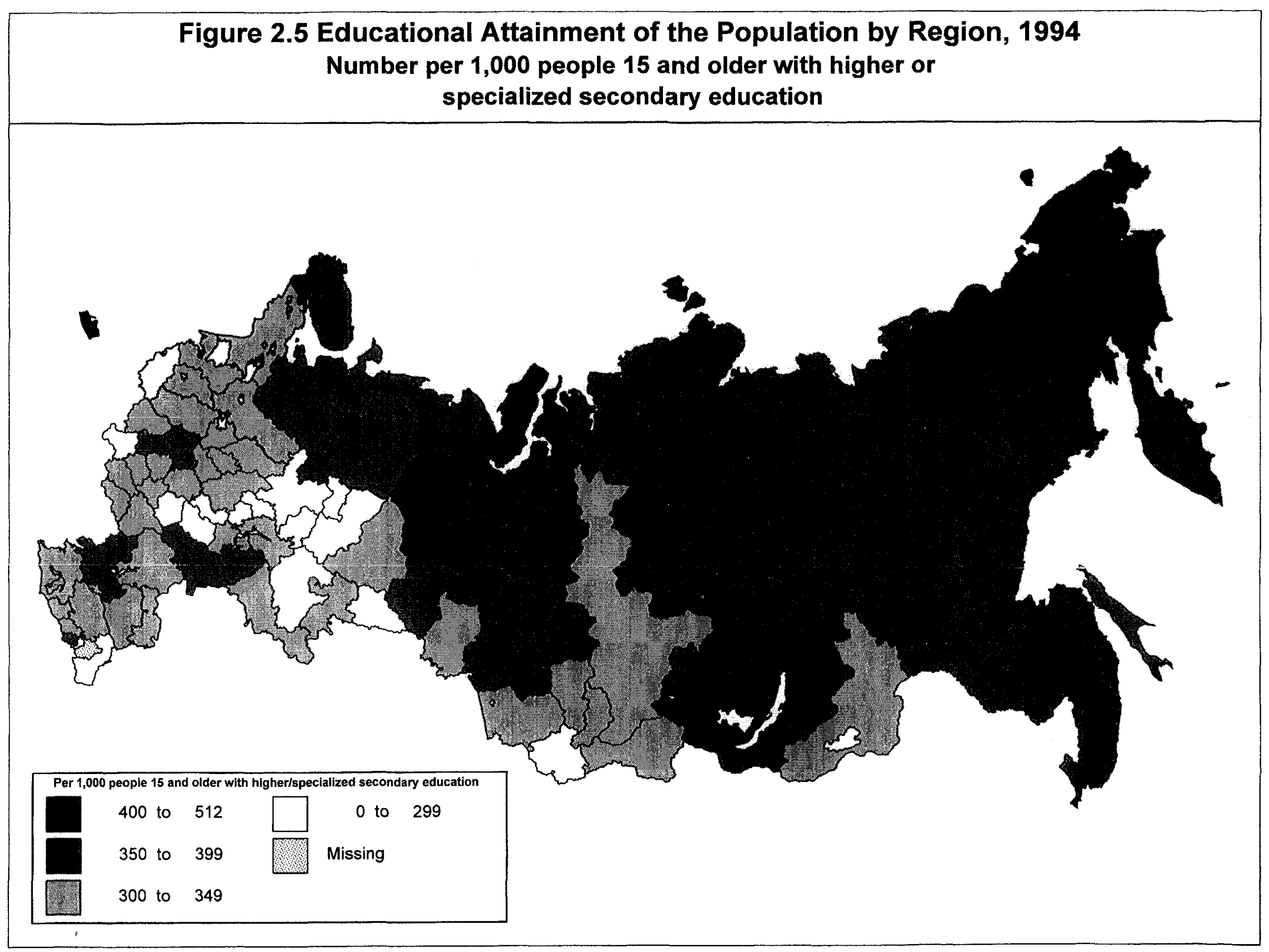


Figure 2.6 Changes in the Shares of Population with Higher and Specialized Secondary Education by Economic region, 1989 to 1994 (per 1,000 persons 15 and older)

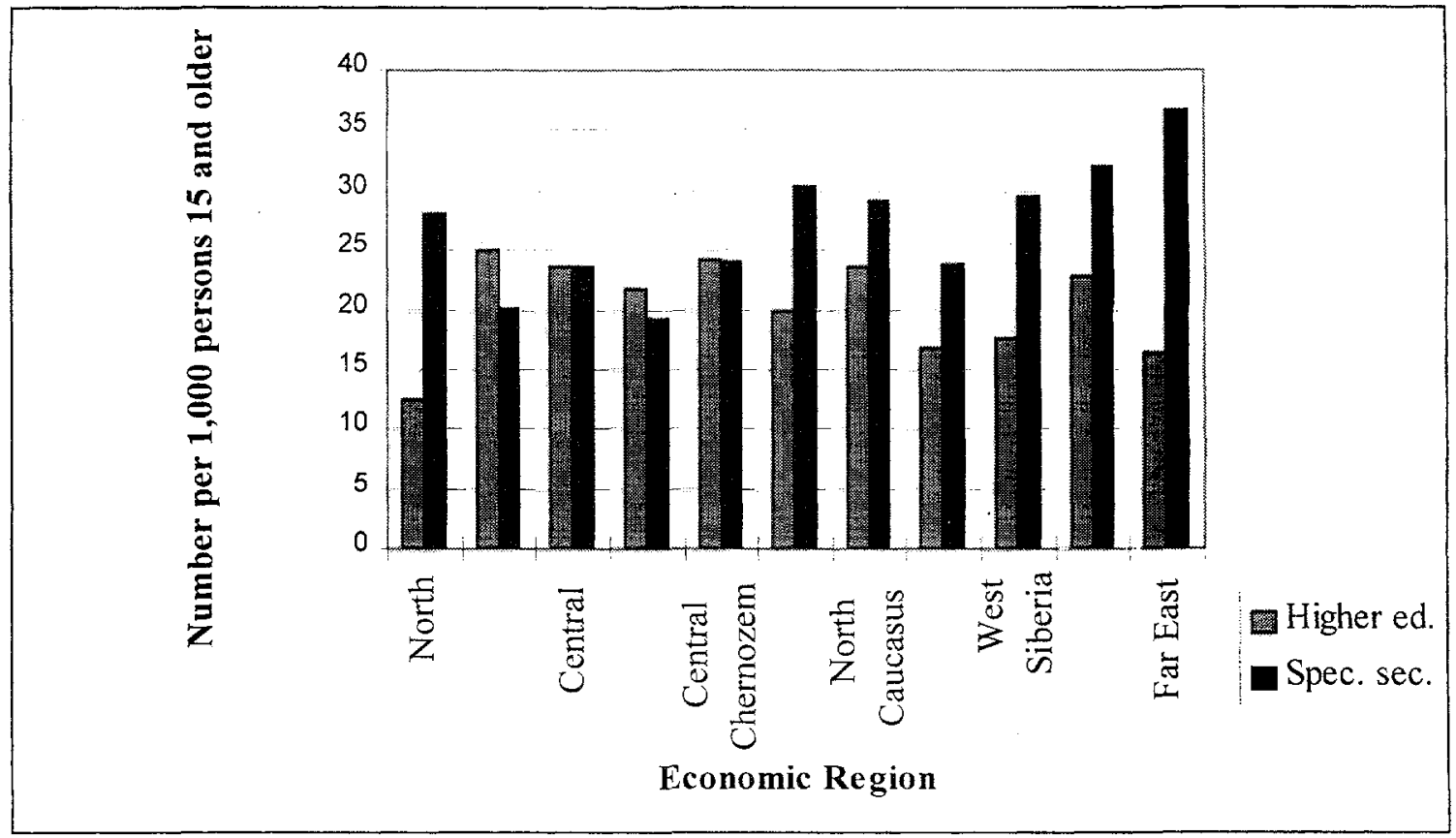

Source: 1989: 1989 census results, CD-ROM. 1994 educational attainment data: Goskomstat Rossii, Obrazovaniye naseleniya Rossii (po dannym mikroperepisi naseleniya 1994 g., 1995.

During the transition period, the myth of full employment has given way to open unemployment, with females often the first to be laid off. As a result, family earning have fallen, and women at home can care for their own children. Both of these factors translate into lower demand for pre-school. On the supply side, as enterprises have been restructured, one of the first benefits shed has been the provision of on-site pre-school facilities (figure 2.7). In 1989, three-quarters of pre-schools were enterprise-based and the remainder under the auspices of local governments. By 1996, the situation had approximately reversed itself, with less than 20 percent of pre-schools owned and operated by enterprises for the benefit of workers and three-quarters run by local governments; another 8 percent are today privately owned institutions. Many pre-schools have introduced fees, further reducing demand. Finally, the declining birthrate has also contributed to contraction at this level (see figure 2.8).

Every region in Russia has experienced some decline in pre-school enrollments since 1990, the declines ranging in size from a quarter to 65 percent of the baseline figures. Enrollment rates have increased in just six regions since 1990, declining in all of the others. Less than half of the one-to-six year old children are enrolled in pre-school education in roughly a third of Russia's 89 regions today. Many of the low-enrollment regions are rural regions, where distance to pre-school facilities still in operation may be an issue. From an education point of view, the big question in regard to the decline in pre-school enrollment rates is how this is affecting the school readiness of children entering compulsory education at the age of 6 . 
Figure 2.7 Pre-Schools in Russia by Subordination, 1989-1996

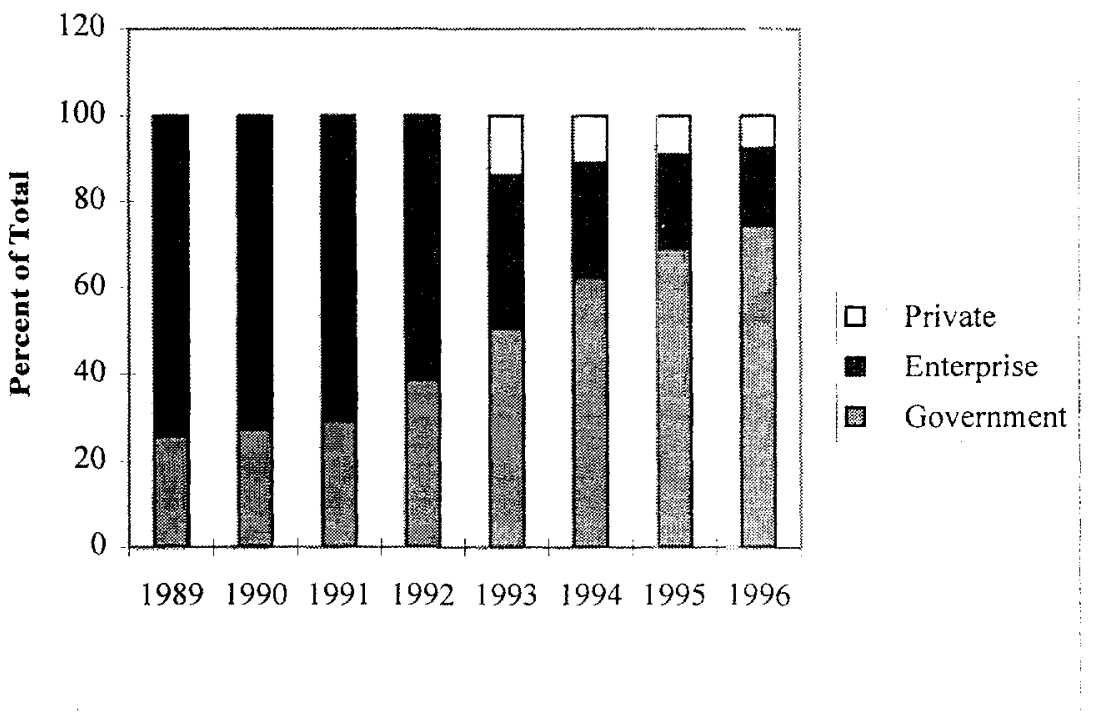

Source: Goskomstat Rossii, Rossiyskiy statisticheskiy yezhegodnik, 1997, p. 184 and UNICEF, TRANSMONEE Database.

Figure 2.8 Selected Data on Pre-Schools in Russia, 1989-1996

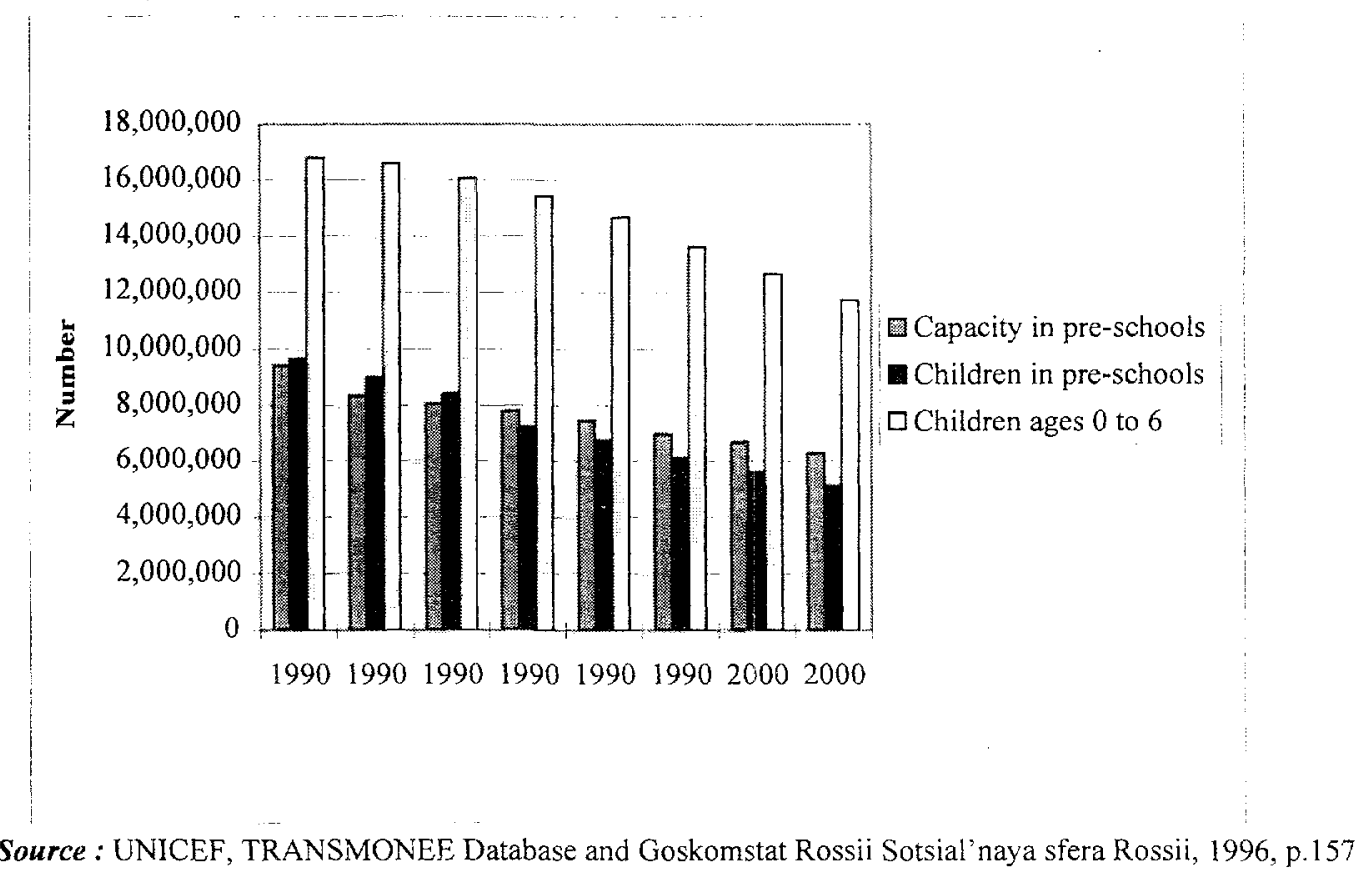




\section{Primary and Secondary Schools}

Primary and secondary schools (grades 1-11) consume the largest share of educational resources in Russia, with, by far, the largest number of students enrolled. During the 1990s, the number of these schools in Russia has increased only moderately (by 875 schools across the country), remaining close to 67,000 in total. The percentage of schools offering a complete education (all 11 grades) has increased slightly. The number of school students (Grades 1-11) increased by 8 percent between 1989 and 1997 , with the average school size going from 296 students to 319 . (See Annex C table 2.)

Among the regions, there has been large variation in the change in number of schools, influenced in part by the varying ability of regions to afford new school construction and in part by demographic factors. Few regions experiencing declining student numbers have closed down schools proportionately, and this has resulted in smaller average enrollments and higher average costs per student.

Gross enrollment rates in primary education have remained roughly the same during the $1990 \mathrm{~s}$ (figure 2.9). Enrollment rates in lower secondary education have declined slightly, from 96 to 93 percent. Upper secondary has experienced the largest declines, with the enrollment rate dropping from 66 to 59 percent. This is attributable to the fact that more students are dropping out of school early in response to economic pressures and the need to find employment.

Figure 2.9 Enrollment Rates by Level of Education, 1989-1996

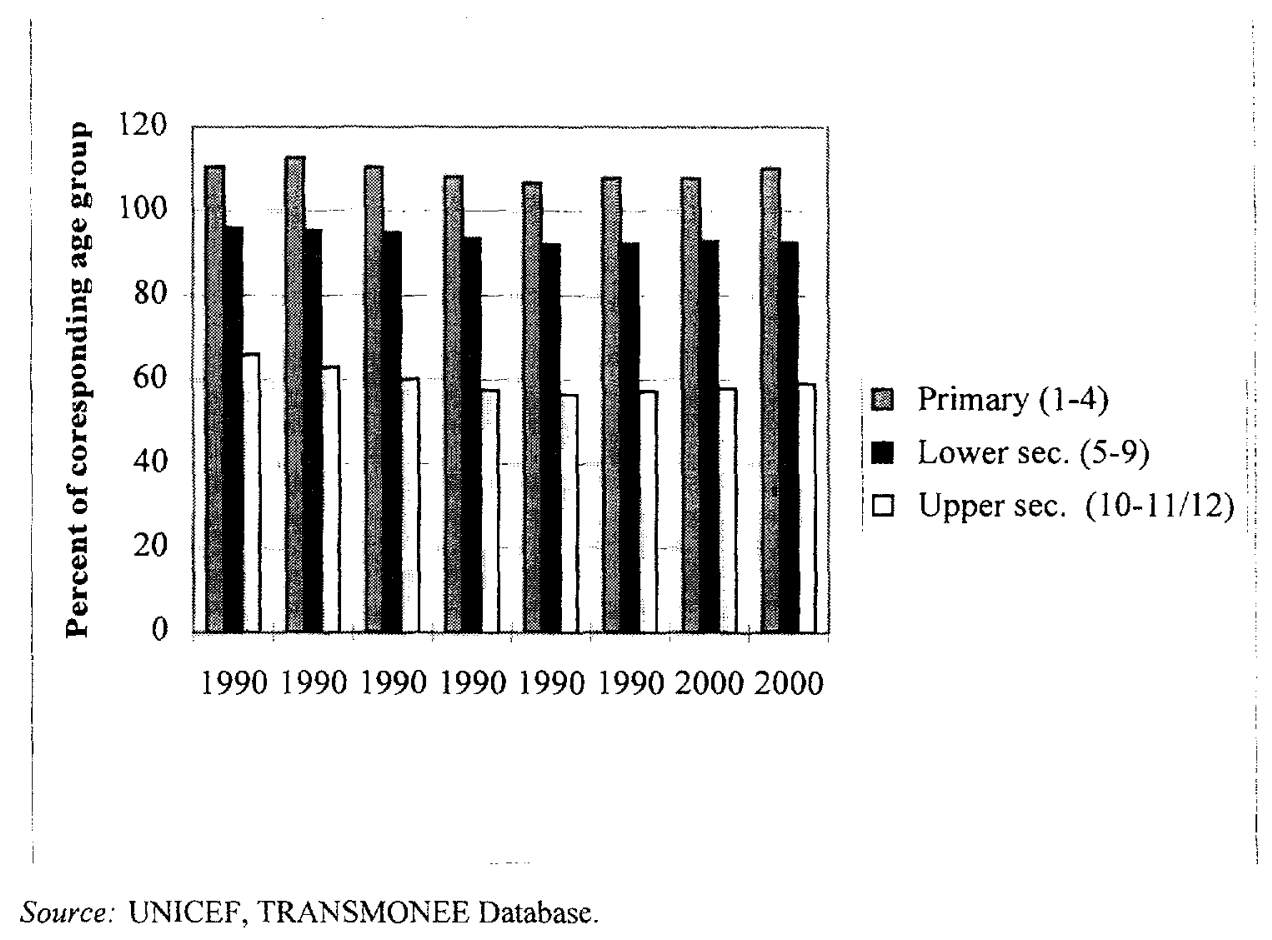

Much of the change in the relative enrollments of Russia's regions during the 1990s has been driven by the migration patterns among them, since a majority of migrants have been parents with schoolage children. The regions in the North, the Far East and Siberia, which tended to have large outmigration, had the largest enrollment declines. Regions such as Ulyanovsk, Krasnodar, Stavropol in central Russia had the largest enrollment increases. 
As these changes have occurred, transfers from central government in support of education have been declining, and regional education administrations have been forced to rely increasingly on local resources. Two factors that underlie the efficiency of education spending and over which local administrators have substantial control are the number of schools and the number of teachers. Changes in average school size and in the student-teacher ratio are examined below.

As reported above, average school size has increased moderately over the first half of the $1990 \mathrm{~s}$, going from 301 in 1990 to 315 in $1995 .^{23}$ In keeping with the national trend, most regions had moderate increases in average school size, but there is a group of regions that have experienced substantial declines in average school size. These regions can be divided into two groups -- those where the reduction in school size was primarily the result of many new schools having been built, and those where the reduction reflected large enrollment declines. Moscow, St. Petersburg, Khanty-Mansiy and Yamal-Nenets okrugs all added many new schools over the period, greatly reducing the average size of schools in those regions. Murmansk, on the other hand, and many of the regions of Siberia and the Far East had reductions in average school size because of greatly reduced enrollments.

Interestingly, the region in Russia that has experienced the largest increase in average school size is Samara, one of the two regions examined in detail as part of this study. Over a period when Samara's enrollments increased by 8 percent, the number of schools declined by 4 percent, increasing the average size of a compulsory school by 45 students. This has achieved economies of scale and resulted in cost savings. The extent to which these changes in Samara in the first half of the 1990s were the result of deliberate policy is uncertain, but for the future, the Region's Education Administration has embarked on an explicit program to consolidate further its rural schools. (See Annex $D$ for further details on Samara's program).

Whereas the number of students increased only moderately in Russia between 1989 and 1996, the number of teachers increased quite significantly, by 25 percent. The result has been a large decrease in the student-teacher ratio, as shown in figure 2.10. There is additional discussion of the issues surrounding teacher numbers and the student-teacher ratio in chapter $I$ and in the policy recommendation section of chapter 3. Nationally, the student-teacher ratio has declined from 15.8 in 1989 to 13.5 in 1996 . In the primary grades, the ratio dropped from 22.7 to 19.2 , while at the secondary level, it dropped from 15.4 to 13.0 .

Between 1985 and 1994, every region in Russia (with just one exception ${ }^{24}$ ) increased the number of teachers in public employment. In most cases, the increases were quite large. Not surprisingly, there has been a strong correlation between the increase in the number of students and increase in the number of teachers. However, the national percentage increase in the number of teachers has been three times higher than the percentage increase in the number of students. While lower student-teacher ratios and smaller classes are preferred by most teachers and may facilitate the educational process, these advantages come at a high cost. Student-teacher ratios are likely to fall further in the years ahead as the smaller cohorts resulting from lower birthrates pass through Russia's school system.

23 Average school size varies considerably across the regions due to a variety of factors. One of the major explanatory factors is the percent of the region's population that is urban. More urban areas (e.g., the federal cities of Moscow and St. Petersburg, the industrial regions of Sverdlovsk and Chelyabinsk, the oil and gas regions of Siberia, Khanty-Mansiy and Yamal-Nenets okrugs, and some regions in the North and Far East) tend to have larger schools, and this results generally in lower unit costs.

24

In Magadan Oblast in the Far East, there was a 39 percent reduction in teachers owing to massive outmigration. Over the same period, Magedlan experienced a reduction of only 30 percent in student enrollments, making Magadan also the only region in Russia where the student-teacher ratio went up rather than down. 
Figure 2.10 Student-Teacher Ratios in Compulsory Education in Russia, 1989-1996

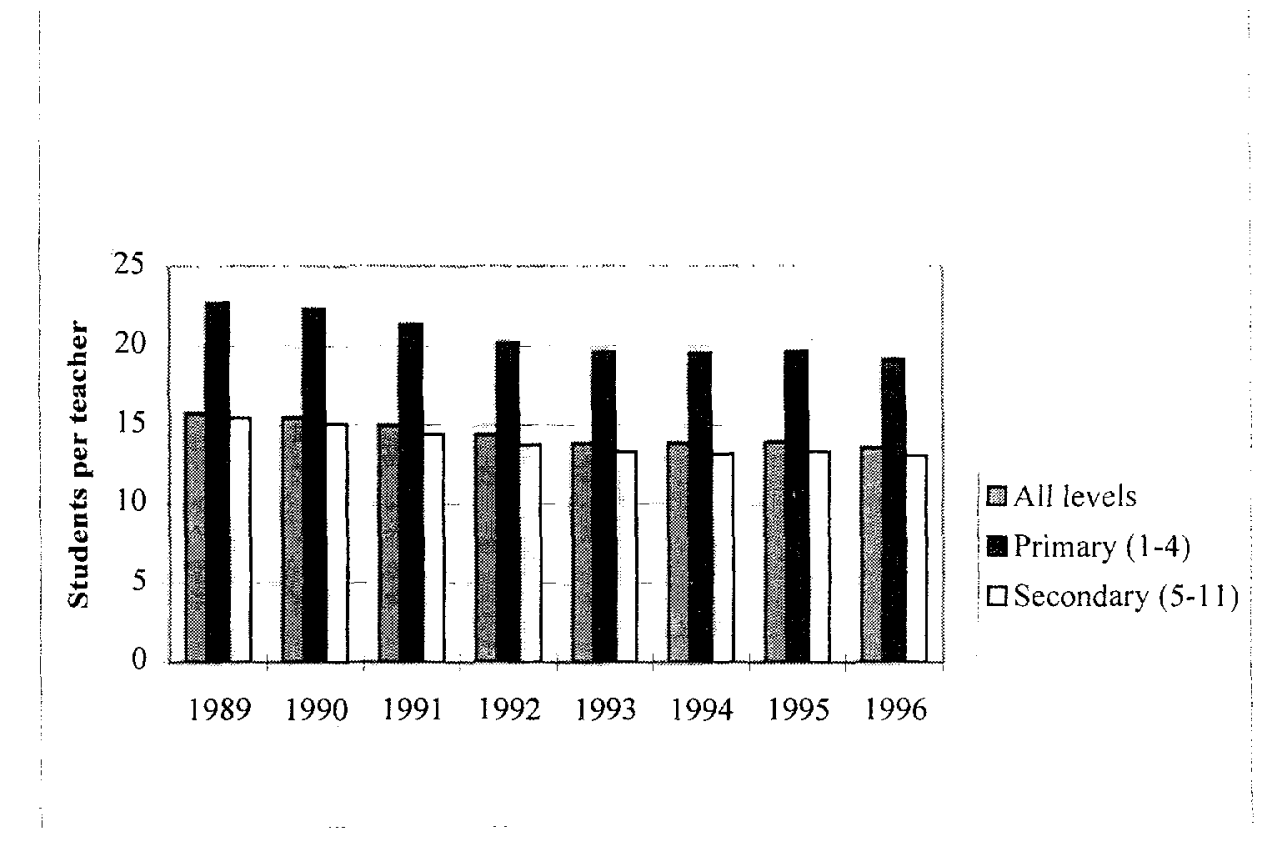

Source: Goskomstat Rossii, Rossiyskiy statisticheskiy yezhegodnik, 1997, pp. 189-190.

\section{Patterns of Education Finance by Region}

Through a series of laws and decrees, the 89 Russian regions and approximately 3,000 lower level units $^{25}$ have been granted substantial control over their own revenues and responsibility for financing a much greater share of education expenditures. This process started shortly after the breakup of the USSR with the passage, in January 1992, of the Law on the Basic Principles of Taxation. This gave the regions control over the use of resources allocated to them for the first time. The regions and the central government now share the proceeds from value-added, income, property and profit taxes. Oblasts have a certain degree of autonomy in this system and often, in fact, when they feel that the federal government is in arrears to them, take more than they are allowed by withholding portions of taxes they are meant to share with the federal government. The current system, however, does not compensate regions in need, because of the shortfall in tax collection and because of the small amounts available for redistribution. Too many regions qualify for transfers. Between 1994 and 1997, between 6 and 10 only of the 89 regions were classified as - "donors" - to the federal budget. All of the rest qualified for transfers from the federal budget.

The federal Law on Local Government, passed in 1995, spells out the major expenditure responsibilities for education at the different levels of government. The federal government retains responsibility for financing most university-level education and research institutions. Pre-school and primary and secondary schools are to be the responsibility of local governments. In practice, most control over levels and types of education expenditures has been retained by the regional (oblast) governments, with the local (raion) governments merely acting as executing agents.

25 The level of geography below the 89 subjects of the federation are 1,869 rural raions and 1,092 cities. In the remainder of this chapter, the 89 subjects of the federation are referred to as "regional government" and the raions and cities as "local government". 


\section{Figure 2.11 Number of Students in Professional-Technical Institutions (PTUs) and Specialized Secondary Institutions (SSIs), 1990-1996}

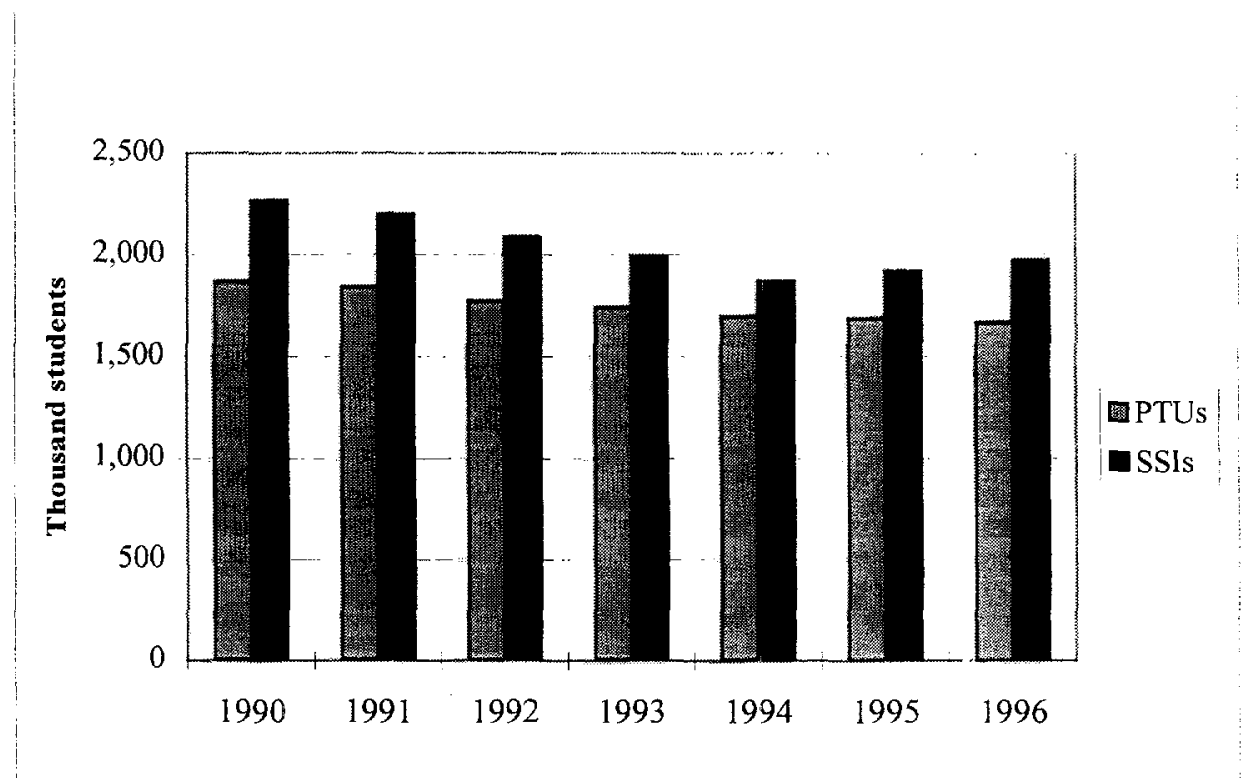

Source: Goskomstat Rossii, Rossiyskiy statisticheskiy yezhegodnik, 1997, p. 199, 200-201.

The exact extent of decentralization of education and other expenditure items varies from one oblast to the next. One reason is that the process is still ongoing, withoblasts implementing federal law at different rates. ${ }^{26}$ For example, the process of devolving responsibility for professional-technical institutions from federal to regional control has just begun. To date, this responsibility has passed to local control only in 4 of the 89 regions (including, by coincidence, Samara and Novgorod, the two cases described in the annexes).

As shown in Annex B, from 1992 to 1996 education spending fell from 5.9 to 2.8 percent as a share of total federal expenditures but rose from 14.9 to 21.1 percent of sub-national budget expenditures. Most of this increase in education spending at the sub-national level occurred at the local (raion) and not at the regional (oblast) level. Of total consolidated expenditures on education in 1992, a third (33.8 percent) was spent at the federal level and just over half (51.8 percent) at the local level. By 1996, the federal share of education spending had fallen to 14.5 percent and the local share had risen to two-thirds $(67.5$ percent $){ }^{27}$ The local share of consolidated regional expenditures also rose over this period from 85.6 to 87.6 percent. There is no region where local level government spending is less than 60 percent of a region's total expenditures on education.

Decentralization of responsibility for education to local governments, when properly designed, can lead to substantial improvements in learning achievement. If, however, the roles and responsibilities of all levels of government are not clearly defined, or if responsibilities are not adequately resourced, inefficiency and inequity across geographic regions and socioeconomic groups can be the result. In post-

\footnotetext{
26 Stewart, Kitty, Financing Education at the Local Level: A Study of the Russian Region of Novgorod, EUI Working Paper ECO No. 98/6, Florence, Italy, April 1998.

27 Frienkman, Lev and Plamen Yossifov, "Decentralization in regional fiscal systems in Russia: trends and link to economic performance", The World Bank, draft September 1998.
} 
Soviet Russia, there are large and growing disparities among regions in terms of natural resources and economic development. Regions with very low per capita incomes and little fiscal capacity must struggle to provide even minimally adequate education and other social services. As discussed elsewhere in this study, it is difficult to assess the effects of decentralization on learning achievement owing to a lack of adequate objective measures of education outcomes. Also, the extent to which financial inputs determine differences in learning outcomes is subject to debate. There are many factors that influence learning achievement, but as stated in a UNICEF report on education in Russia and other transition states, "it is difficult to believe that injections of money will have no effect on learning in a school with a leaking roof, broken windows, insufficient heating, and few textbooks and where teachers are obliged to take second jobs to supplement meager salary that are paid in arrears. 28

One measure of economic activity and income at the regional level is gross regional product (GRP). GRP figures are available for the years 1994 and 1995 for 79 regions of Russia (all but the 9 subordinated autonomous okrugs and Chechniya). The stark differences across regions is shown in Annex table G.4. The oblast with the highest income per capita in 1994 was the oil- and gas-rich region of Tyumen, with a per capita GRP 2.9 times the national average. This was followed by the diamond-rich Sakha republic with a figure 2.3 times, and Moscow City was 1.7 times the national average. At the other extreme was Ingushetiya, just one-fifth the national average. The two regions studied in detail and described in the annexes, while closer to the national average, are themselves very different -- Samara's GRP per capita was 1.4 times the average while Novgorod's was about seven-tenths of the average. The distribution of income is negatively skewed, with 53 of the 79 regions having per capitaGRP's below the national average and only 26 having incomes above it. Inequality across the regions rose slightly between 1994, when the coefficient of variation was 0.48 , and 1994 , when it was 0.54 .

Comparisons of GRP and other economic indicators over time and across regions is made quite difficult by the rapid price inflation that occurred after 1992 as the result of price liberalization policies. Changes in price levels were influenced by transportation and energy costs and, therefore, not the same in all parts of the country. Regions further from concentrations of economic activity in central Russia tended to have the highest price increases. If regional deflators are applied to the GRP figures, the coefficient of variation narrows somewhat. ${ }^{29}$

In 1997, GDP in Russia as a whole was 62 percent of what it was in 1991 in real terms. During this period, public education spending remained between 3.5 and 4.4 percent of GDP. Education's share of the overall consolidated budget increased from 3.8 percent in 1992 to 13.5 percent in 1997 . This was not due to a reallocation of expenditures towards education but rather a relative cut back in various expenditures, mainly production subsidies. Of the amount spent on education from the consolidated budget, slightly over half ( 51.6 percent) in 1995 went to secondary education, with 17 percent to preschool education, 11 percent to vocational education, and 9 percent to higher education.

Of federal spending on education, higher education gets the largest share, and an increasing share (61 percent in 1996 versus 54 percent in 1994). Primary vocational education's share has fallen (17 percent in 1996 versus 21 percent in 1994), reflecting in part the transfer of responsibility for PTUs to sub-national units. The share of federal expenditures going to secondary vocational institutions has also decreased (13 percent in 1996 versus 14 percent in 1994).

\footnotetext{
28 UNICEF, International Child Development Center, Florence, Italy, Education for All?, Regional Monitoring Report, No. 5, 1998.

29 Regional Deflators, as referred to here, are regional adjustments to account for price differences among regions.
} 
Data on regional education spending (available for 1995 only) show that over 80 percent goes to pre-school and compulsory education -- 20 percent for pre-schools and 61 percent for compulsory education. Only 6 percent of regional education budgets went to vocational education in 1995 . However, this figure is expected to rise as control and responsibility for funding primary vocational facilities continues to be transferred to the regions. The data available on regional expenditures for three years, 1994 to 1996, show a quite inconsistent pattern. Expenditures on salaries went from 35 percent of education spending in 1994 down to 32 percent in 1995 and then back up to 39 in 1996 . Combined expenditures on capital investment and civil works fell slightly between 1995 and 1996 (from 6 to 5 percent). The large residual of unidentified spending (about half of the total of regional education spending) makes for only very tentative conclusions.

With fiscal decentralization, per capita spending on education is quite dependent on regional income, and this, we have seen, varies significantly. The regions have little power to raise additional revenue. The tax rates and shares taken by the center are set by the federal government, limiting the flexibility of lower-level governments to make adjustments to suit their own needs. The fiscal redistribution mechanisms that have been introduced in post-Soviet Russia have caused expenditure levels across regions to converge only slightly. The ratio between the GRP per capita of Tyumen (the region with the highest GRP per capita) and Ingushetiya (the region with the lowest) was 9.5 to 1 in 1995 . The ratio between the spending per capita of the regions with highest and lowest spending was 8.7 to 1.30 There is a high correlation across regions between gross regional product per capita and total spending per capita $\left(\mathrm{r}^{2}=0.42\right)$. This calculation for 1995 is arrived at using regionally adjusted figures for both GRP and expenditures.

The question then remains of how the differences in total public expenditures influenced spending on education. The average share of regional budgets allocated to education rose slightly between 1994 and 1996, going from 22 to 24 percent. However, differences across regions rose as well. The coefficient of variation of the share spent on education went from 0.17 in 1994 to 0.22 in 1996 . This variation is influenced by the age structure of some regions as well as other factors.

On average in 1996, about 41 percent of regional education spending was spent on salaries, a slight increase over 1994, when it was 38 percent. The dispersion among regions devoting very large shares to salaries and those devoting smaller shares narrowed somewhat over this period. During a period of rapid price inflation, education wages have increased much slower than most other wages (figure 2.12), and the dispersion in education wages across regions has increased significantly. The ratio of the average wage of all workers in the region with the highest wages to that in the region with the lowest wages increased from 3.4 in 1990 to 9.8 in 1995 . The ratio of the average education wage in the region with the highest wages to that in the region with the lowest increased from 2.7 to 4.7 . The reason for this is that, while much of the Russian economy was privatized over this period, allowing wages to adjust to market forces, most of education remains in the government sector, where wages are largely administered. ${ }^{31}$ The average wage in education was 69.8 percent of the national average wage for all sectors in 1996, only a slight decline from 71.0 percent in 1989 (figure 2.13). Within education, workers in specialized secondary institutions remain the highest paid, followed by those in higher education, while those in compulsory schooling are the lowest paid. Teachers' salaries are set at the federal level (with only small differences allowed at the regional level). This is another example of an important expenditure item in local education budgets that is determined centrally and over which local education administrations have little or no control. During a period of chronic wage arrears and rapidly changing demands for education among the regions, this would be an important prerogative for education administrators to be given.

\footnotetext{
${ }^{30}$ The ratio between the revenues per capita of the regions with the highest and lowest revenues was 16.3 to 1 .

31 This discussion does not take into account the fact that teachers, in the public sector, are more likely than workers in general to receive their wages in arrears and/or paid in kind.
} 
Based upon the statistics available, about half of education spending is unaccounted for, falling into a large unidentified category, making the analysis of regional spending difficult. However, with overall education spending diverging across regions and the amounts spent on salaries converging, one spending category that seems to be diverging is "capital improvements and civil works." This is obviously a discretionary category in times of tight budgets, and as shown in figure 2.13 , construction and repair of school facilities is an area that has been sorely neglected in most regions in recent times. New construction has fallen off, and as school buildings deteriorate or the spatial demands in education change, the financial resources needed to repair or to re-configure existing buildings are not available. The construction of pre-schools fell by 91 percent between 1990 and 1996 (figure 2.13). Part of this decline is justified by the decline in the number of pre-school children, but the drop from 284,000 new pre-school places in 1989 to 20,000 in 1996 far exceeds the decline in the number of children. Similar declines have occurred at other levels, even where enrollments have not fallen. New construction fell by 72 percent in compulsory education, 79 percent in primary professional education, 83 percent in specialized secondary education and 79 percent in higher education. Though information is skimpy, purchases of capital and other pedagogical equipment seem to have undergone comparable declines.

These trends occur at a time when the Russian education system needs new plant and equipment to accommodate changes in the curriculum brought about by the transition to a market economy. These figures paint a bleak picture of the deteriorating condition of Russian schools. At a time when school administrators must make difficult choices between paying teachers' salaries or the heat and electricity bills necessary to keep schools open, capital improvements and repairs are viewed as luxuries and are routinely delayed. Deferred maintenance may go largely unnoticed in the short run but spells disaster for education in the long run.

It is estimated that compulsory schools in need of capital repair rose from 28 percent of the total in 1991 to 35 percent in 1997 . Those condemned rose from 5.7 to 6.0 percent. Once again, there is evidence of enormous variation across regions in the ability to construct new schools and to make repairs and improvements in existing ones. There is a high correlation $(0.35)$ between a region's GRP and per student spending on capital construction and improvements meaning that for every additional ruble in per capita income, a region was able to devote one-third of a ruble to school construction or improvements. While in 1995 the average region of Russia spent 85,000 rubles per school-age student on capital repairs and civil works in schools, six regions (Moscow, Belgorod, Tatarstan, Samara, Bashkortostan and Yakutiya, all regions with GRPs well above the national average) spent over 140,000 rubles per student. At the other extreme, nearly half of Russia's regions ( 35 of the 78 where reliable data were available) spent less than 40,000 rubles per student. 
Figure 2.12 Wages of Education Workers versus National Average

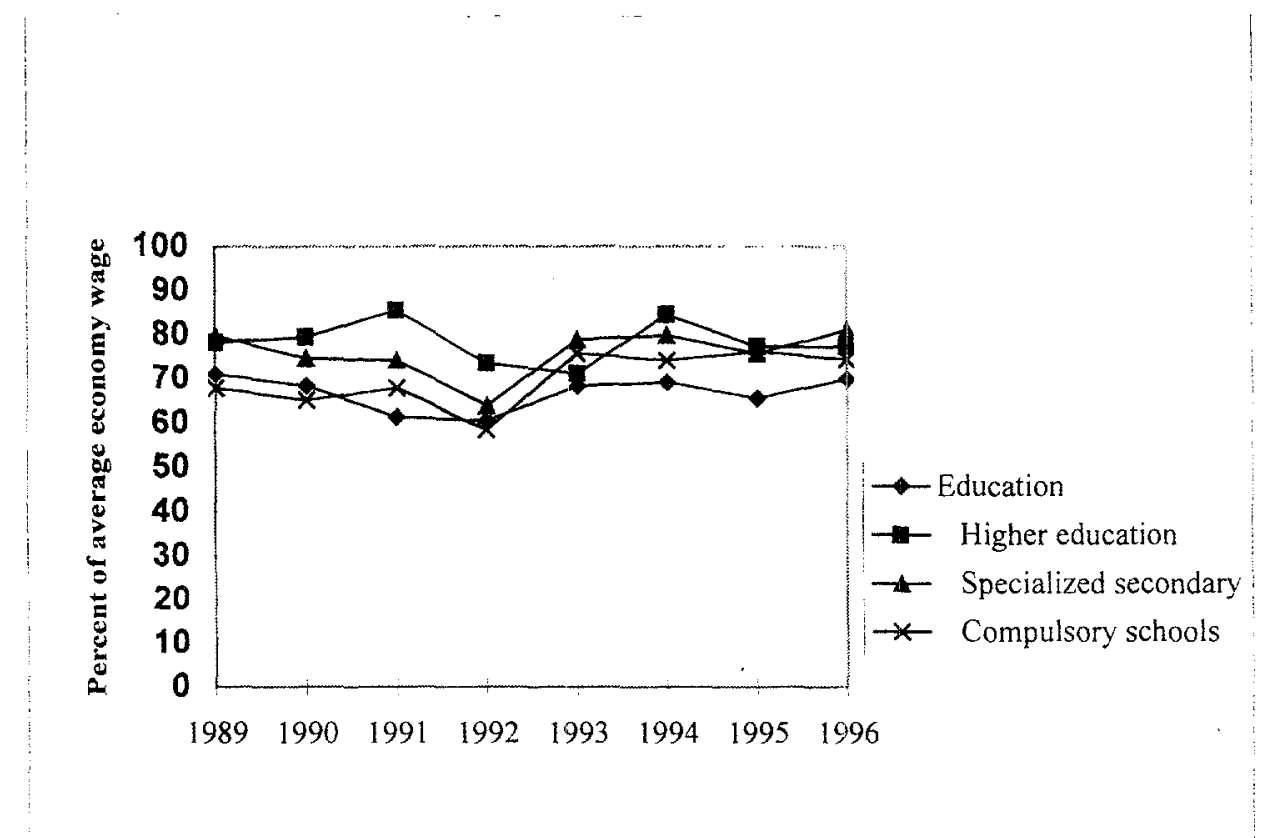

Source: Goskmstat Rossii, Obrazovaniye v Rossiyskov Federatsii v 1992 godu, p. 8 and Goskomstat Rossii, Statisticheskiy byulleten' No. 10, 1998.

Figure 2.13 Construction of New School Places by Level of Education, 1989-1996

Source: Goskomstat Rossii, Stroitel'stvo v Rossii, 1996, p. 43; Goskomstat Rossii, Statisticheskiy byulleten' No. 10, January 1998, p. 98; and Russian Ministry of Education, Statisticheskiye dannyye po sisteme obrazovaniya, 1998, pp. 20-22 


\section{PROMISING POLICY OPTIONS}

Based on the identification of issues in Chapter 1 and the analysis of data in Chapter 2, Chapter 3 presents policy options for the consideration of policymakers in the Russian Federation. The World Bank has already had discussions about these policy options with education officials and selected stakeholders. Some of the recommendations have been modified to reflect the knowledge of these experts or to incorporate factual corrections from them. As the policy dialogue continues and as this report is disseminated to a wider audience, it is expected that other recommendations could be expanded or modified.

\section{RESOURCE MobILIZATION AND EFFICIENCY}

\section{Funding Mechanisms}

Given current inefficiencies, as discussed in Chapter 1, in the mobilization and utilization of resources for education in Russia, a formula-based approach to funding education and training in Russia is a promising option. A demand-side "capitation" funding formula allocates funds based on the number of pupils enrolled in each institution, with some differences to reflect factors known to affect per-pupil costs such as: (i) the level of education (with more allocated usually for upper levels); (ii) the type of school (more for vocational than for general); and (iii) the extent to which a school's location is urban or rural (since education tends to cost more in rural areas, as a function of smaller scale of operation in rural schools and higher market prices for many inputs in rural areas ${ }^{32}$ ). Under this type of demand-side funding formula, "money follows students." In other words, payment is based on the number of pupils rather than the historical budget level or the number of teachers currently employed.

The design and implementation of this kind of capitation funding formula would increase the transparency and improve the efficiency of education funding at regional and sub-regional levels. A scheme such as this might require additional funds in the short run, to cover the costs of development and initial implementation, but in the medium term, formula-based funding can result in significant budgetary savings which can be used to increase teachers' salaries, increase the textbook-student ratio, purchase equipment or improve educational infrastructure. One additional cost associated with the introduction of capitation funding is the need to develop special training initiatives at the raion level for education administrators who will be given responsibility for implementation of fiscal aspects of the reform.

Quite significant savings can be expected by implementing all of the suggestions for efficiencies outlined above. However, in order to ensure that the efficiency dividends gained from resource reallocation are re-invested in the educational system and not siphoned off as part of the general budget system reduction at regional or raion levels, a federal policy is needed. In addition, in order to ensure optimum use of the existing budget, the Federal Government might wish to provide incentives to those regions most willing to undertake systemic educational reforms. One suggestion would be for the overall

32 However, it is not clear to what extent the former state farms continue to provide in kind contribution (including fuel and some repair maintenance) to the local school system. 
equalization grant for eligible regions to be split into sectoral components, i.e., one for education, one for child benefits, and so forth. The corresponding components would be allocated to regions on a matching principle and through the Treasury system. The former will help to ensure that local governments spend some amounts of their own money for these purposes; the latter will provide some Federal control over what regions spend so as to ensure that minimally acceptable levels are maintained for education and all of the money is not siphoned off for other purposes (for example, operating hospitals or repairing roads).

\section{Class Size}

The situation of small average class sizes was discussed above. Significant cost savings could be expected from a phased program of increasing class sizes, particularly outside large towns and cities where they are already relatively large. This recommendation, however, provoked sharp reactions from many Russian stakeholders, who argue that factors causing smaller classes in rural areas would be difficult, if not impossible, to address within the Russian context Studies in OECD countries, however, show that average class size may be increased to about 30 pupils in most subjects without significant declines in pupil learning. Moreover, the potential for savings from increases in student-teacher ratios can be dramatic while the cost of failing to initiate some staffing efficiency measures would ultimately be very high ${ }^{33}$. To illustrate, an increase in average class size from 20 to 26 pupils decreases the teacher requirement by more than 20 percent. If teachers' salaries comprise about 40 percent of what the regions of Russia now spend on education, this means that regional spending on education could be reduced by about 8 percent by investing in larger classes, a very big dividend. These savings could be applied to alleviating the fiscal difficulties now confronting many regions, be used to address teachers' salary arrears, now common in many regions, or be re-invested to create a richer teaching environment with better equipment and more textbooks and materials per studerit.

The recommendation to reduce the number of teachers runs counter to the frequently heard claim from Russian educators that there is already a shortage of teachers in the system. As already discussed, however, this apparent shortage of teachers is a corollary of the small class sizes, particularly those found in rural areas. Many regions now address the "shortage" of teachers by hiring retirees on a contractual basis. ${ }^{34}$ An immediate measure to increase class sizes would be the introduction of a package of reforms that would phase out such contracts over time and reduce the numbers of such teachers Independent of the inefficiency of small classes at the present time, a reduction in the number of teachers is inevitable in the future as school cohorts fall owing to a 40 percent reduction in births between 1989 and 1996.

\section{Teachers Pay and Working Conditions}

A major challenge for MGPE will be the development of a comprehensive strategy to improve teachers' salary levels and effectiveness. A system of reforms affecting pay, working conditions and provision of both pre-service and in-service teacher training could be expected to yield significant savings and enhance the quality of education. This report recommends that a package of reforms be put in place which would balance the incentives of better training and timely payment of salaries with a change in the contractual basis of teachers' employment, whereby more teaching would be done per week in larger

\footnotetext{
33. In April 1999, the MGPE commented that an overall increase in class sizes would not be acceptable to either parents or teachers. The Ministry commented further that the size of classrooms and the condition of the infrastructure in many Russian schools would make such an increase in class size very costly while smaller classes would require the production of new teaching materials and the re-training of teachers. The Bank agrees that efficiency improvements would almost certainly require large up-front investment costs.

34 In some parts of Russia, for example, the two regions (Samara and Novgorod) visited in March 1998, such "pensioners" account for about 10 percent of those currently teaching.
} 
classes. ${ }^{35}$ In making this recommendation, the Bank research team is aware that this issue is complex and politically sensitive and probably cannot be addressed adequately in the current economic situation. Nevertheless, some first steps should be taken towards rationalization. One such step which would increase student teacher ratios (and thus the efficiency of the system) would be to avoid the danger of underutilized teacher time by training fewer, highly specialized teachers of one subject only and by introducing a policy of training teachers to teach more than one subject.

\section{Merging of Educational Institutions}

A further measure that could increase the efficiency of the system and yield significant savings would be to merge institutions, where there is obvious overlap in the missions of adjacent institutions and, hence, missed economies of scale, or where existing schools are too small to be economically viable. The scope for this strategy is probably greatest in relation to vocational education and in the case of small rural schools. Larger schools can afford better equipment, more pedagogical materials and a greater choice of subjects, all of which will ultimately benefit learning achievement. While the merging of rural schools has already been piloted in some regions of European Russia (Annex D), this strategy may not be suitable for all regions, especially in the North and Far East, due to climatic or geographical factors. ${ }^{36}$ In remote areas, distance education and other applications of new teaching technologies may be an alternative approach to achieve economies of scale and to improve the learning environment.

\section{Cost Recovery}

A central component of Russia's educational reform program will be to give schools more autonomy and greater financial accountability. A key recommendation of this report is that each school should have its own independent bank account with the right to receive and retain private funds and with the responsibility for budget management delegated to the school director. Overall improvements in efficiency can thus be achieved since, with a flexible and transparent system of budgeting, savings made under one budget heading can be transferred to another. As part of this change, schools could be encouraged to introduce higher levels of cost recovery for secondary education classes and for the purchase and/or rental of textbooks, especially wherever parents desire greater choice and can afford to pay. In addition and where possible, education establishments should examine ways of increasing revenues by renting out property and increasing the role of private provision of services to education establishments. The incentives to increase cost recovery encountered in Samara provide useful examples of what is achievable in Russia at the moment (Annex D. But to achieve equity, Government should ensure that no qualified student is denied access to education of the same quality because of the family's inability to pay. ${ }^{37}$

35 The issue of teachers' salaries and conditions of work was seen as contentious by those who contributed comments to an earlier draft of these policy recommendations. To quote the Moscow City Education Administration, "One should not raise the issue of increasing the normative workload of teachers at general schools, because the actual working time of a teacher is not limited to classroom work only. Teachers also do a lot of extracurricular activities (over and above the regular workload). If the issue of increasing the workload of teachers is to be raised at all, this should be done only after teachers' salaries have been brought to international levels."

36 The issue of merging small rural schools is extremely sensitive in Russia. However, some scope for rationalization is possible. See Annex D for a description of relevant initiatives in Samara Region.

37 Feedback on this study from the MGPE agrees with the authors' concern about growing inequity in the education system. Hence it is important that any policies to promote greater cost recovery are not at the expense of poorer members of society. 


\section{Utilities}

A further way to generate cost savings would be the introduction of action plans in the regions of Russia to reduce the current high expenditures in education institutions on heat, electricity and water (although, as we have seen, 90 percent of these payments are met through non-cash forms of mutual payments). A key element of a savings plan would be the installation of metering devices in schools, with budgets for utility payments allocated to the schools themselves, and permission granted to use (some part of) the potential savings derived from the more efficient use of utilities to meet the needs of the schools. Significant savings for the education sector could be expected from such plans. The investment costs could usually be recouped in just two-to-three years.

\section{QUALITY}

\section{Teacher Training}

The availability of good teacher training and retraining programs may be the single most important factor in the reform of Russian education, since, without well-trained educators, the quality of the system will decline over time and new graduates will be unable to satisfy the requirements of the changing labor market. The development of new and successful policies will require that MGPE co-operate with regional education administrators to help design and put in place a program that would re-orient the pedagogical universities and other providers of teacher training and that would result in flexible and market-relevant programs of training and retraining including provisions for training additional teachers of foreign languages and for training teachers to teach more than one discipline. Increases in standard class sizes will have implications for how classes are taught and will necessitate the introduction of in service training in new methodologies of teaching and learning.

\section{Standards, Testing and Certification}

MGPE should take the lead in reforming the State Education Standard which needs to reflect a more qualitative, less quantitative view of education. Ideally, revised standards would concentrate more on outcomes (student achievement, especially, marketable competencies and skills) and less on input (compulsory content) and process (duration of course, hours per week). Minimum requirements should be expressed as much as possible in terms of students' active competencies and skills. MGPE should also ensure that present registration and licensing procedures for educational institutions be continued and that accreditation procedures be made more transparent and streamlined. At regional and local levels, the aim should be to simplify and regionalize State Attestation services and eliminate excessive bureaucracy.

The introduction of a national system of student assessment will entail the transparent administration of tests with the correct mixture of practical, oral and written components (including, where appropriate, computer-administered tests to ensure fairness and access). A national system is necessary, but a federal structure to cover all 89 regions would be a practical impossibility. Therefore, consideration should be given to a decentralized system, with cross-regional branches, each one covering a number of regions and each having sub-regional testing centers. Specific measures to improve systems of vocational qualifications could include practices common in Germany, Ireland and other OECD countries, where employers and unions are involved in course design and assessment and in the introduction of "portable" certification to promote labor mobility. 


\section{Educational Data}

The information needs of the various decision-makers at the federal and regional levels should be identified, and a set of basic indicators should be developed that will provide Russian policymakers with a baseline profile of the knowledge, skills and competencies of students. Indicators should include: (i) a set of contextual indicators that will provide insight into how such skills relate to important demographic, social, economic and educational variables; (ii) trend indicators that will become available because of the on-going, cyclical nature of data collection and would include system outcomes, student outcomes, labor market outcomes, and social outcomes; and (iii) a knowledge base that will lend itself to further focused policy analysis. In order to continue the cooperation with OECD and with Goskomstat, MGPE should take steps to strengthen the capacity of the Education Statistical Unit. Decisions will be needed on the level and frequency of data aggregation, collection and methods to make the outcomes public, taking into account decentralization and regional disparities.

\section{MARKeT LinkageS}

For primary vocational education (i.e., for the PTUs), the ongoing process of devolving responsibility for the operation of institutions to the regions should be accompanied by measures to facilitate greater institutional coordination and efficiency from the pooling of resources and from the involvement of employers and students in the design of programs. For second-level technical and professional education, governance of the system and the authority and relative spheres of influence of sectoral ministries (e.g., the Ministry of Health for medical education) and professional associations should be clarified and agreed.

Consideration should be given to making vocational training (including adult education, retraining and life-long learning, and the interface of training with the labor market) the joint responsibility of both MPGE and the Ministry of Labor, with public and private responsibilities clearly defined and agreed by both ministries. Where feasible, the responsibility for paying for specific training courses should be assumed by employers who could be eligible for tax reductions or other incentives.

Experience in OECD countries suggests that it is preferable at the secondary education level for all students to emphasize general rather than technical subjects, leaving the acquisition of more specialized vocational skills to post-secondary institutions or to enterprises, which can offer a combination of on-thejob and formalized training for their workers. The Russian system of vocational education may be too entrenched to benefit from this experience at this time. Nevertheless, some consideration should be given to reform measures, including: (i) the development of a comprehensive strategy to reorient PTUs and eventually integrate them into the general secondary stream; (ii) delaying specialization until at least the final year of secondary education; (iii) de-linking schools from a single SOE (wherever this still exists); and (iv) orienting course content to new technology-related subject matter and the inclusion in the curriculum of "introduction to the world of work" and career orientation modules.

Some technikums could be merged to create institutions relevant to regional labor markets while, at the same time, addressing individual student needs. Simultaneously, some of the special secondary schools could be merged with these new institutions, especially in localities dominated by only a few specializations. This would reduce duplication of course offerings between the special secondary schools and the vocational schools. It may be feasible to create new structures that would incorporate the higher end of some of the technikums that have become or are in the process of becoming colleges. These colleges could achieve a formal status similar to polytechnical colleges in the UK. 


\section{EQUTTY AND ACCESS}

The introduction of measures to ensure equality of access and choice for those who cannot pay for education services should be a priority of MGPE. The creation of objective evaluation systems (sponsored by MGPE) will benefit those who are in danger of being squeezed from the education system, especially from the opportunity to attend a good secondary school or university, because of inability to pay. Reliable examinations administered to recognized norms will create more equitable access to higher level education. Publicly recognized certification will create more opportunities in the labor market for graduates of the vocational education system. In addition, regional governments might wish to create scholarship schemes in support of those educational services that attract high levels of private funds currently and are, therefore, liable to become inaccessible to those without the resources to pay. 


\section{REFERENCES}

Canning, Mary. 1998. New Directions for Vocational Education, Russia. Washington, D.C.: The World Bank.

Castro, Claudio de Moura; Feonova, Marina; Litman, Anna. 1997. Education and Production in the Russian Federation: What are the Lessons: Paris: International Institute for Educational Planning, UNESCO.

Bolotov, Victor A., Lenskaya, Elena A., and Shauiln, Valentin N. 1995. The Reform of Education in New Russia: A Background Report for the OECD Review of Russian Education. Moscow: Ministry of Education.

Freinkman, Lev and Yossifov, Plamen. September 1998. Decentralization in Regional Fiscal Systems in Russia: Trends and Link to Economic Performance. Washington, D.C.: The World Bank.

Goskomstat Ross, Statisticheskiy Sbornik. Moscow 1997.

Heleniak, Timothy. 1997. Internal Migration in Russia During Economic Transition. In: Post-Soviet Geography and Economics, no 2, pp. 81-104

Le Houerou, Philippe; Gold E; and Katash E. 1994. Budget Coverage and Government Finance in the Russian Federation. Report No. IDP-138. Washington, D. C.: The World Bank.

Mertens, F. J. H. 1995. Reflections on Education in Russia. ACCO, Leuven/Amersfoort

Organization for Economic Co-operation and Development. 1998. Russian Federation. Review of National Policies for Education, Center for Co-operation with N-Members

Organization for Economic Co-operation and Development. 1998 Review of Tertiary Education and Research Policy in the Russian Federation. Draft Examiners' Report, DEELSA/ED (98)14

Organization for Economic Co-operation and Development. 1997. Education At A Glance, OECD Indicators.

Stewart Kitty. Sept 1997. Are Intergovernmental Transfers in Russia Equalizing. Innocenti Occasional Papers, Economic and Social Policy series no 59.

United Nations Childrens Fund. 1998. Education for All?, Regional Monitoring Report, No. 5, International Child Development Center, Florence, Italy.

Voogt, Joke; Plomp, Tjeerd. 1998. Education Standards and Assessment in the Russion Federation: Results from Russian-Dutch Cooperation in Education. ACCO, Leuven/Amersfoort.

Wallich, Christine. 1992. Fiscal Decentralization in Russia. In: Studies of Economies in Transformation 6, Washington, D.C.: The World Bank. 
Table 01 Ruble-Dollar Exchange Rate

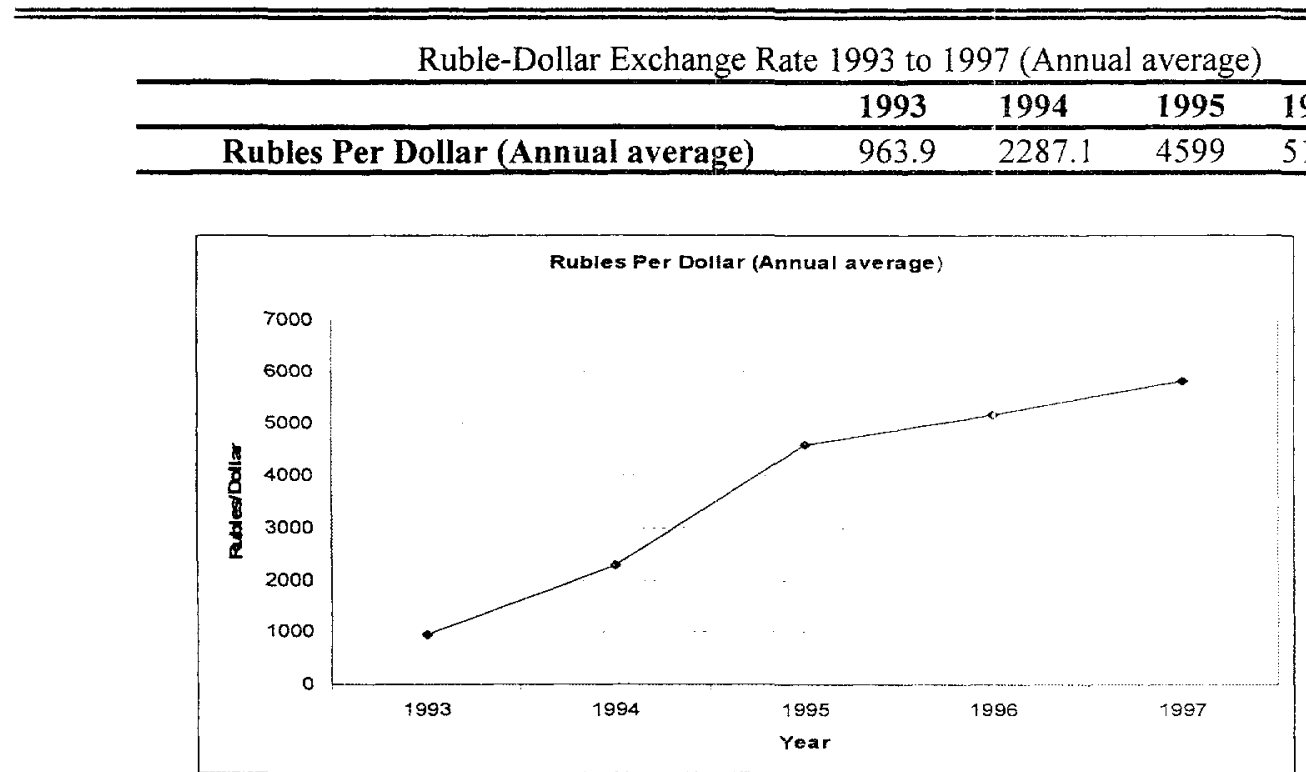

Ruble-Dollar Exchange Rate 1998 (Monthly)

\begin{tabular}{ll}
\hline Rubles Per Dollar (End of period) & $\mathbf{1 9 9 8}$ \\
\hline January & 6.04 \\
\hline February & 6.048 \\
\hline March & 6.1 \\
\hline April & 6.111 \\
\hline May & 6.172 \\
\hline June & 6.23 \\
\hline July & 6.238 \\
\hline August & 10.5 \\
\hline September & 15.7 \\
\hline October & 16.65 \\
\hline November & 17.9 \\
\hline December & 20.83 \\
\hline
\end{tabular}

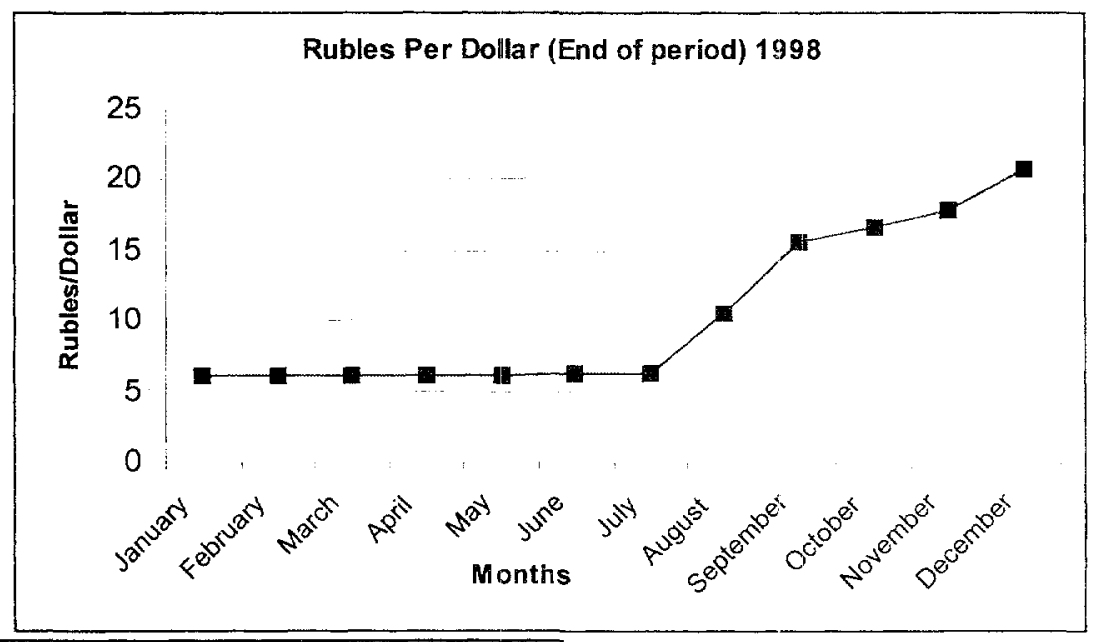

Sources and notes: Data are Moscow Inter-bank Foreign Currency Exchange rates., On January 1, 1998, Russia introduced a ruble denomination, where 1,000 old, pre 1998 rubles were equivalent to new 1998 ruble. 


\section{ANNEX A: MATRIX OF POLICY OPTIONS}

\begin{tabular}{|c|c|c|c|c|}
\hline OBJECTIVE & MEANS & RATIONALE & Federal Level (Comment) & $\begin{array}{l}\text { Regional Level } \\
\text { (Comment) }\end{array}$ \\
\hline $\begin{array}{l}\text { 1. Improve resource } \\
\text { mobilization and } \\
\text { system } \\
\text { efficiency }\end{array}$ & $\begin{array}{l}\text { (a) Design formula based } \\
\text { capitation funding mechanisms } \\
\text { within the existing budgetary } \\
\text { envelope. }\end{array}$ & $\begin{array}{l}\text { Improved efficiency of expenditures } \\
\text { would allow pupil demand to be the } \\
\text { determining factor in the reallocation of } \\
\text { scarce resources. }\end{array}$ & $\begin{array}{l}\text { Safeguard equity and ensure optimum } \\
\text { use of the budget through incentives and } \\
\text { splitting equalization grants into sectoral } \\
\text { components allocated: (i) on a } \\
\text { matching principle, and (ii) through the } \\
\text { Treasury system. }\end{array}$ & $\begin{array}{l}\text { The introduction of capitation } \\
\text { funding will require the } \\
\text { development of special training } \\
\text { initiatives at the regional level for } \\
\text { education administrators who will } \\
\text { be given responsibility for the } \\
\text { implementation of the fiscal } \\
\text { aspects of the reform. }\end{array}$ \\
\hline & $\begin{array}{l}\text { (a) Improve efficiency through: } \\
\text { (i) increasing class sizes where } \\
\text { feasible; and (ii) reducing } \\
\text { numbers of non-teaching staff }\end{array}$ & $\begin{array}{l}\text { Significant cost savings could be } \\
\text { expected from increasing class sizes } \\
\text { and reducing the numbers of non } \\
\text { teachers among the education } \\
\text { workforce. }\end{array}$ & $\begin{array}{l}\text { There is an opportunity for reducti on } \\
\text { in teacher numbers owing to } 40 \text { percent } \\
\text { reduction in births between } 1989 \text { and } \\
1996 \text {. }\end{array}$ & $\begin{array}{l}\text { Increased class sizes not possible } \\
\text { in all parts of the RF because of } \\
\text { geographical conditions. }\end{array}$ \\
\hline & $\begin{array}{l}\text { (c) Increase school autonomy and } \\
\text { financial accountability and } \\
\text { encourage cost recovery and cost } \\
\text { savings where feasible. }\end{array}$ & $\begin{array}{l}\text { More autonomy and ownership of } \\
\text { school budgets will improve efficiency } \\
\text { of school operations. With a flexible } \\
\text { and transparent system of budgeting, } \\
\text { savings made under one budget } \\
\text { heading can be transferred to another. }\end{array}$ & $\begin{array}{l}\text { To achieve equity Government should } \\
\text { ensure that no qualified student is } \\
\text { denied access to education of the same } \\
\text { quality because of the family's inability } \\
\text { to pay. }\end{array}$ & $\begin{array}{l}\text { Train school principals in budget } \\
\text { management. } \\
\text { Reduce expenditures in education } \\
\text { institutions on heat, electricity and } \\
\text { water. Install metering dcvices in } \\
\text { schools, with the potential savings } \\
\text { to meet the needs of the schools. } \\
\text { Channel savings into repair of } \\
\text { school buildings. }\end{array}$ \\
\hline & $\begin{array}{l}\text { (d) Improve teachers } \\
\text { effectiveness through better } \\
\text { working conditions, timely salary } \\
\text { payments; and availability of } \\
\text { relevant training. }\end{array}$ & $\begin{array}{l}\text { Package of reforms essential to address } \\
\text { working conditions. Provision of } \\
\text { modern pre-service and in-service } \\
\text { training programs. }\end{array}$ & Pay teachers" salary arrears. & \\
\hline & $\begin{array}{l}\text { (e) Merge small and inefficient } \\
\text { schools. }\end{array}$ & $\begin{array}{l}\text { Larger schools will allow for } \\
\text { economies of scale, better equipment, } \\
\text { greater choice of subjects and an } \\
\text { improved learning environment. }\end{array}$ & $\begin{array}{l}\text { In remote areas, distance education and } \\
\text { other applications of new teaching } \\
\text { technologies may be an alternative } \\
\text { approach to achieve economies of scale } \\
\text { and improve the learning environment. }\end{array}$ & $\begin{array}{l}\text { The integration of smaller schools } \\
\text { may not be suitable for all regions, } \\
\text { especially in the North and Far } \\
\text { East, due to climatic or } \\
\text { geographical factors. }\end{array}$ \\
\hline
\end{tabular}




\section{ANNEX A: MATRIX OF PO LICY OPTIONS}

\begin{tabular}{|c|c|c|c|c|}
\hline OBJECTIVE & MEANS & RATIONALE & Federal Level (Comment) & $\begin{array}{l}\text { Regional Level } \\
\text { (Comment) }\end{array}$ \\
\hline $\begin{array}{l}\text { 2. Improve the } \\
\text { quality of education } \\
\text { inputs, processes } \\
\text { and outputs. }\end{array}$ & $\begin{array}{l}\text { (a) Re-orient the pedagogical } \\
\text { universities and other providers of } \\
\text { teacher training to ensure flexible } \\
\text { and market-relevant programs of } \\
\text { training and retraining. }\end{array}$ & $\begin{array}{l}\text { Without well-trained educators, the } \\
\text { quality of the system will decline over } \\
\text { time and new graduates will be unable to } \\
\text { satisfy the requirements of the changing } \\
\text { labor market. }\end{array}$ & $\begin{array}{l}\text { Consensus between MGPE and other } \\
\text { stakeholders on design and financing of } \\
\text { pre-/in-service training programs. }\end{array}$ & $\begin{array}{l}\text { Increases in standard class } \\
\text { sizes will have implications } \\
\text { for how classes are taught } \\
\text { and will necessitate the } \\
\text { introduction of in service } \\
\text { training in new } \\
\text { methodologies of teaching } \\
\text { and learning. }\end{array}$ \\
\hline & $\begin{array}{l}\text { (b) reform the State Education } \\
\text { Standard which needs to reflect a } \\
\text { more qualitative, less quantitative } \\
\text { view of education. }\end{array}$ & $\begin{array}{l}\text { Revised standards would concentrate } \\
\text { more on outcomes. Minimum } \\
\text { requirements should be expressed as } \\
\text { much as possible in terms of students' } \\
\text { active competencies and skills. }\end{array}$ & $\begin{array}{l}\text { Consensus between MGPE and all } \\
\text { interested stakeholders regarding } \\
\text { acceptable standards for an agreed } \\
\text { number of core subjects would be } \\
\text { desirable. }\end{array}$ & $\begin{array}{l}\text { The Education Law requires } \\
\text { Regional/Federal standards } \\
\text { to be set jointly to guide } \\
\text { regional aspects of the } \\
\text { curriculum. Harmonization } \\
\text { of Federal and Regional } \\
\text { standards to be agreed } \\
\text { among stakeholders. }\end{array}$ \\
\hline & $\begin{array}{l}\text { (c) strengthen and make more } \\
\text { transparent registration, licensing } \\
\text { and accreditation for educational } \\
\text { institutions. }\end{array}$ & $\begin{array}{l}\text { Re accreditation of Universities, MGPE } \\
\text { has been working since } 1991 \text { on the basis } \\
\text { of draft guidelines only. Municipalities } \\
\text { are responsible for accreditation of } \\
\text { schools, but process is uneven across RF. }\end{array}$ & $\begin{array}{l}\text { At both Federal and Regional levels, } \\
\text { revision of procedures and needs } \\
\text { assessment for State Attestation Services } \\
\text { are needed. Remit of Federal Attestation } \\
\text { Service to be reviewed and operation } \\
\text { streamlined. }\end{array}$ & $\begin{array}{l}\text { Local Authorities unable to } \\
\text { deliver evaluations of school } \\
\text { quality owing to lack of } \\
\text { capacity. Aim should be to } \\
\text { simplify and regionalize } \\
\text { State Attestation Services } \\
\text { and eliminate unnecessary } \\
\text { procedures. }\end{array}$ \\
\hline & $\begin{array}{l}\text { (d) Introduce a national system of } \\
\text { student assessment. }\end{array}$ & $\begin{array}{l}\text { Transparent administration of tests with } \\
\text { the correct mixture of practical, oral and } \\
\text { written components (including computer- } \\
\text { administered tests, where possible) will } \\
\text { promote fairness and access. }\end{array}$ & $\begin{array}{l}\text { A national system is necessary, but a } \\
\text { federal structure to cover all } 89 \text { regions } \\
\text { may be a practical impossibility. }\end{array}$ & $\begin{array}{l}\text { Consideration should be } \\
\text { given to a decentralized } \\
\text { system, with cross-regional } \\
\text { branches, each one covering } \\
\text { a number of regions and } \\
\text { each having sub-regional } \\
\text { testing centers. }\end{array}$ \\
\hline
\end{tabular}


ANNEX A: MATRIX OF PO LICY OPTIONS

\begin{tabular}{|c|c|c|c|c|}
\hline OBJECTIVE & MEANS & RATIONALE & Federal Level (Comment) & $\begin{array}{l}\text { Regional Level } \\
\text { (Comment) }\end{array}$ \\
\hline $\begin{array}{l}\text { 3. Improve market } \\
\text { linkages and } \\
\text { increase } \\
\text { responsiveness to } \\
\text { changing social and } \\
\text { economic needs. }\end{array}$ & $\begin{array}{l}\text { (a) For PTUs: less specialized } \\
\text { programs and closer integration } \\
\text { with general secondary stream; } \\
\text { delay specialization; include new } \\
\text { technology and labor market } \\
\text { relevant skills in core curriculum. } \\
\text { (b) For Tecnikums: clarify } \\
\text { governance and restructure (some } \\
\text { mergers) to reflect market } \\
\text { conditions. }\end{array}$ & $\begin{array}{l}\text { OECD experience suggests that general } \\
\text { transferable skills rather than technical } \\
\text { subjects should be taught at primary } \\
\text { vocational level. Acquisition of specialized } \\
\text { vocational skills should be postponed either } \\
\text { to post-secondary or to on-the-job training } \\
\text { in enterprises. }\end{array}$ & $\begin{array}{l}\text { Devolve responsibility for vocational } \\
\text { education and training systems to regional } \\
\text { level, to the extent that this is possible, } \\
\text { ensuring that adequate funding follows } \\
\text { the devolved responsibility }\end{array}$ & $\begin{array}{l}\text { Creation of mechanisms to } \\
\text { make training demand } \\
\text { driven and responsive to } \\
\text { local labor market through } \\
\text { involvement of employers, } \\
\text { unions and community } \\
\text { groups. }\end{array}$ \\
\hline $\begin{array}{l}\text { 4. Introduce } \\
\text { measures to ensure } \\
\text { equality of access } \\
\text { and choice. }\end{array}$ & $\begin{array}{l}\text { Standards-linked examinations } \\
\text { administered to recognized norms } \\
\text { and publicly recognized } \\
\text { certification will create more } \\
\text { equitable access and more } \\
\text { opportunities. }\end{array}$ & $\begin{array}{l}\text { The creation of objective evaluation } \\
\text { systems (sponsored by MGPE) will benefit } \\
\text { those who cannot pay, and yield valuable } \\
\text { information on access and outcomes. }\end{array}$ & $\begin{array}{l}\text { Identify and remove unnecessary barriers } \\
\text { (legal, structural, institutional, } \\
\text { procedural) to equal access for all on the } \\
\text { basis of merit. }\end{array}$ & $\begin{array}{l}\text { Creation of targeted } \\
\text { scholarship schemes by } \\
\text { Regional Governments. } \\
\text { Target funds at raion } \\
\text { level for categories of } \\
\text { those who are less well off. }\end{array}$ \\
\hline
\end{tabular}


ANNEX B: SELECTED DATA ON EDUCATION FINANCE IN RUSSIA, 1989-1997

\begin{tabular}{|c|c|c|c|c|c|c|c|c|c|}
\hline & 1989 & 1990 & 1991 & 1992 & 1993 & 1994 & 1995 & 1996 & 1997 \\
\hline Total public expenditures on education (million rubles) & & & & 679.4 & 6,9178 & 27,5287 & 57,2952 & 83,7511 & \\
\hline Education expenditures as a share of GDP (percent) & & & & 358 & 403 & 436 & 351 & 375 & 407 \\
\hline Education expenditures as share of consolidated budget (pe & & & & 376 & 440 & 436 & 1240 & 1283 & 1350 \\
\hline As share of total federal budget expenditures (percent) & & & & 590 & 380 & 357 & 328 & 280 & $35 !$ \\
\hline As share of total regional budget expenditures (percent) & & & & 1489 & 1531 & 1983 & 1980 & 2111 & $2 ! 14$ \\
\hline \multicolumn{10}{|l|}{ Average waye in education, total } \\
\hline (1989-91 rubles, 1992-97 thousand rubles) & 1836 & 2029 & 3388 & 37 & 401 & 1522 & 3092 & 5515 & 5874 \\
\hline Higher educational institutions & 202.6 & 2360 & 4723 & 45 & $4 ! 8$ & 1862 & 36.51 & 6106 & \\
\hline Specialized secondary institutions & 2064 & 221.8 & 4100 & 39 & 463 & 1760 & 3580 & 6392 & \\
\hline Compulsory schools & 1755 & 1934 & 3749 & 36 & 445 & 1634 & 3595 & 5875 & 5922 \\
\hline Compared to average wage in economy (percent) & 710 & 684 & 614 & 605 & 683 & 691 & 655 & 698 & 628 \\
\hline Higher educational institutions & 783 & 79.5 & 856 & 735 & 712 & $84 \mathrm{~s}$ & 773 & 773 & \\
\hline Specialized secondary institutions & 79.8 & 747 & 743 & 639 & 789 & 799 & 758 & 809 & \\
\hline Compulsory schools & 679 & 65.2 & 679 & 584 & 758 & 741 & 761 & 743 & 633 \\
\hline \multicolumn{10}{|l|}{ New school construction } \\
\hline Pre-schoois (thousand places) & 284.0 & 225.0 & 1470 & 957 & 603 & 421 & 282 & 200 & \\
\hline Compulsory schools (thousand places) & 6450 & 545.0 & 396.0 & $303 \mathrm{I}$ & 2963 & 194.0 & 2180 & 1522 & \\
\hline Primary-professional instituions (thousand places) & & 14.3 & & 84 & 120 & 84 & 30 & 30 & \\
\hline Specialized secondary institutions (thousand sq. meters) & & 67.8 & & 228 & 110 & 454 & 136 & 115 & \\
\hline Higher educational institutions (thousand sq meters) & & 204.0 & & 1393 & 846 & 611 & 627 & 639 & \\
\hline \multicolumn{10}{|l|}{ Schools in need of capital repair or condemned } \\
\hline Number of compulsory schools needing capital repair & & & 19,637 & & 21.821 & & 23,170 & 23,600 & 24,100 \\
\hline As a share of all compulsory schools & & & 281 & & 311 & & 321 & 346 & 350 \\
\hline Number of compulsory schools which are condemed & & & 4,014 & & 4,086 & & 4,153 & 4,200 & \\
\hline As a share of all compulsory schools & & & 57 & & 58 & & 59 & 60 & \\
\hline
\end{tabular}

Siources and noles

Total public expenditures on education, 1992-1996: UNICEF, TRANSMONEE Database

Education expenditures as a share of GDP: Ministry of Finance, repons on budget execution 1993-1998

Education expenditures as a share of consolidated budget: Data for 1993 and 1995-1997 are from Ministry of Finance Data for 1992 and 1994 are from World Bank,

Fiscal Management in the Russian Federation, 1996.

Education expendiutres as share of total federal budget expenditures: Ministry of Finance, reports on budget execution 1993-1998 and Ministry of Education,

Statisticheskiye Data from the two sources may not be strictly comparable

Education expendiutres as share of total regional budget expenditures: Ministry of Finance, reports on budget execution 1993-1998

Average wages in education, including by level, 1989-1991: Goskomstat Rossii, Obrazovaniye v Rossiyskoy Federatsii v 1992 godu, p 8

Average wayes in education, including by tevel, 1992-1997: Goskomstat Rossii, Statisticheskiy byulleten No 10, 1998 Data for 1997 are January-October

New school construction: Goskomstat Rossii, Stroitel'stvo v Rossii, 1996, p. 43; Goskomstat Rossii, Statisticheskiy byulleten No 10, January 1998, p 98; Russian

Ministry of Education, Statisticheskiye dannyye po sisteme obrazovaniya, 1998, pp 20-22

Schools in need of capital repair or condemed: Russian Ministry of Education, Statisticheskiye dannyye po sisteme obrazovaniya, 1998, pp 20-22 The Russian term v avariynom sostoyanii could also be translated as 'in need of emergency repair.

Not available 
Annex C2: Selected Data on Compulsory Schools in Russia, 1989-1997

\begin{tabular}{|c|c|c|c|c|c|c|c|c|c|}
\hline & 1989 & 1990 & 1991 & 1992 & 1993 & 1994 & 1995 & 1996 & 1997 \\
\hline Number of compulsory schools, total & 67,270 & 67,571 & 67,891 & 68,270 & 68,110 & 68,187 & 68,446 & 67,815 & $67,16 i$ \\
\hline Primary (classes 1.4 ) & 17,491 & 17,376 & 17,289 & 17,215 & $\{7,23$ & 17,142 & 17,124 & 16,750 & 16,216 \\
\hline Basic (classes 5-9) & 16,291 & 15,509 & 14,928 & 14,539 & 14,145 & 13,944 & 13,755 & 13.430 & 13,205 \\
\hline Secondary (classes 10-11/12) & 31,646 & 32,835 & 33,813 & 34,650 & 34,859 & 35,222 & 35,661 & 35,700 & 35,784 \\
\hline Special education & $\mathrm{I}, 842$ & 1,851 & 1,861 & 1.866 & 1,875 & 1,870 & 1,906 & 1,935 & 1,956 \\
\hline Number of evening or shift schools & & 2,100 & 2,000 & 1,900 & 1,900 & 1,800 & 1,800 & 1,800 & \\
\hline Compulsory school students by type of school, total & $19,897,000$ & $20,328,000$ & $20,355,000$ & $20,503,000$ & $20,565,000$ & $21,104,000$ & $21,52 !, 000$ & $21,146,000$ & $21,416,000$ \\
\hline Primary (classes 1-4) & 320,000 & 353,000 & 308.000 & 429,000 & 468,000 & 509,000 & 541,000 & 527,000 & 516,000 \\
\hline Basic (classes 5-9) & $1,762,000$ & $1,610,000$ & $1,501,000$ & $1,447,000$ & $1,397,000$ & $1,390,000$ & $1,378,000$ & $1,330,000$ & $1,276,000$ \\
\hline Secondary (classes 10-11/12) & $17,457,000$ & $17,996,000$ & $18,170,000$ & $18,227,000$ & $18,297,000$ & $18,779,000$ & $19,156,000$ & $18,843,000$ & $19,140,000$ \\
\hline Special education & 358,000 & 369,000 & 376,000 & 400,000 & 403,000 & 426,000 & 446,000 & 446.000 & 484,000 \\
\hline Compulsory school students by level of education, total & $22,090,729$ & $22,376,685$ & $22,449,880$ & $22,464,379$ & $22,517,949$ & $23,029,935$ & $23,453,857$ & $23,615,168$ & \\
\hline Primary (classes $1-4)$ & $7,281,710$ & $7,596,416$ & $7,737,674$ & $7,797,126$ & $7,755,142$ & $7,869,263$ & $7,903,198$ & $7,692,877$ & \\
\hline Lower secondary (classes 5-9) & $10,270,083$ & $10,322,023$ & $10,342,223$ & $10,394,396$ & $10,527,642$ & $10.820,851$ & $11,082,140$ & $11,294.460$ & \\
\hline Upper secondary (classes 10-11/12) & $4,003,694$ & $3,907,117$ & $3,812,274$ & $3,684,815$ & $3,653,509$ & $3,726,595$ & $3,824,509$ & $3,939,034$ & \\
\hline Special education & 535,242 & 551,129 & 557,709 & 588,042 & 581,656 & 613,226 & 644,004 & 688,791 & \\
\hline Primary enroliment rates (classes $1-4$ ) & 1107 & 1129 & 110.6 & 108.3 & 1067 & 1079 & 1079 & 1102 & \\
\hline Lower secondary enrollment rates (classes 5-9) & 96.0 & 95.4 & 950 & 936 & 921 & 923 & 930 & 926 & \\
\hline Upper secondary enrollment rates (classes $10-11 / 12$ ) & 66.0 & 631 & 603 & 576 & 565 & 573 & 579 & 592 & \\
\hline Number or teachers by level of education, total & $1,400,000$ & $1,442,000$ & $1,497,000$ & $1,561,000$ & $1,624,000$ & $1,664,000$ & $1,687,000$ & $1,746,000$ & \\
\hline Primary (classes $1-4$ ) & 320,200 & 339,967 & 362,618 & 385,020 & 394,809 & 401,449 & 401,557 & 401,264 & \\
\hline Secondary (classes 5-11) & 924,100 & 943,700 & 982.900 & $1,025,900$ & 1.069 .728 & $1,107,450$ & $1,121,019$ & $1,167,657$ & \\
\hline Other & 155,700 & 158,333 & 151,482 & 150,080 & 159,463 & 155,101 & 164,424 & 177,079 & \\
\hline Student/teacher ratio, total & 158 & 155 & 150 & 144 & 139 & 138 & 139 & 135 & \\
\hline Primary (classes 1-4) & 22.7 & 223 & 213 & 203 & 106 & 190 & 197 & 192 & \\
\hline Secondary (classes 5-11) & 15.4 & 15.1 & 144 & 137 & 133 & 131 & 133 & 130 & \\
\hline Number of schools with two or three shifts & & 20,700 & 22,100 & 22,900 & 23,300 & 23,800 & 23,400 & 23,300 & \\
\hline As a percent of all schools & & 306 & 326 & 335 & 342 & 349 & 342 & 344 & \\
\hline Number of students in schools with two or three shifts & $4,306,780$ & $4,575,182$ & $4,819,816$ & $4,930,212$ & $5,021,839$ & $5,153,859$ & $5,279,822$ & $5,288,910$ & \\
\hline As a percent of all students & & 23 & 24 & 25 & 25 & 25 & 25 & 25 & \\
\hline Number of gymnasia & & & 77 & 200 & 328 & 433 & 482 & 536 & 627 \\
\hline Number of lycea & & & 100 & 306 & 569 & 727 & 800 & 885 & $97 \%$ \\
\hline Number of students in gymnasia & & & 49,500 & 116,900 & 214.500 & 284,200 & 331,700 & 372,800 & 426,000 \\
\hline Number of students in lycea & & & 78.600 & 234,800 & 433,200 & 553.000 & 641,200 & 715,100 & 793,000 \\
\hline
\end{tabular}

Number of compulsory schools and number of compulsory school students by type of school: Goskomstat Rossii, Rossiyskiy statisticheskiy yezhegodnik, 1997, p 189 The number of evening or shift schools is not included in the totals for the number of compulsory schools

Compulsory school students by level of education: UNICEF, TRANSMONEE Database

Enrollment rates by level of education: UNICEF, TRANSMONEE Database Gross enrollments Primary is as share of children 7.9 years old. lower secondary is as share of children 10-14 years old, and upper secondary is as share of children $15-17$ years old

Number of teachers by level of education: Totals are from Goskomstat Rossii, Rossiyskiy statisticheskiy yezhegodnik, 1997, 100 Breakdowns by level are from UNICEF, TRANSMONEE Database. Data on totals were rounded to thousands while breakdowns were given to last digit

Number of schools and students in multi-shift schools, Goskomstat Rossii, Rossiyskiy statisticheskiy yezhegodnik, 1997, p 184 and UNICEF, TRANSMONEE Database

Number of gymnasia and lycea and students in each: Ministry of Education of Russia, Statisticheskiye dannyye po sisteme obrazovaniya, 1998

Not available 
Annex C3: Selected Data on Vocational and Professional Schools in Russia, 1989-1997

\begin{tabular}{|c|c|c|c|c|c|c|c|c|c|}
\hline & 1989 & 1990 & 1991 & 1992 & 1993 & 1994 & 1995 & 1996 & 1997 \\
\hline Number of primary professional institutions (PTUs) & & 4,328 & 4,321 & 4,269 & 4,273 & 4.203 & 4,166 & 4,114 & \\
\hline Number of students in PTUs (thousands) & & 1.867 & $\{, 84]$ & 1.773 & 1.742 & 1,699 & 1,689 & 1.670 & \\
\hline $\begin{array}{l}\text { Number of students accepted to PTUs (thousands) } \\
\text { Number of graduates from PTUs (thousands) }\end{array}$ & & $\begin{array}{l}1,252 \\
1,272\end{array}$ & $\begin{array}{l}1,234 \\
1,141\end{array}$ & $\begin{array}{l}1,096 \\
1,039\end{array}$ & $\begin{array}{r}1.007 \\
922\end{array}$ & $\begin{array}{l}949 \\
878\end{array}$ & $\begin{array}{l}928 \\
841\end{array}$ & $\begin{array}{l}899 \\
821\end{array}$ & \\
\hline Number of teachers in PTUs & & & 165,635 & 154,500 & 154,400 & 154,100 & 150,800 & 150.600 & 156,600 \\
\hline Number of specialized secondary institutions & 2,595 & 2.603 & 2,605 & 2,609 & 2,607 & 2,574 & 2,612 & 2,608 & \\
\hline $\begin{array}{l}\text { Sudents in specialized secondary institutions (thousan } \\
\text { Number of students accepted (thousands) } \\
\text { Number of graduates (thousands) }\end{array}$ & $\begin{array}{r}\text { nब13338 } \\
768 \\
640\end{array}$ & $\begin{array}{r}2,270 \\
754 \\
637\end{array}$ & $\begin{array}{r}2,202 \\
732 \\
623\end{array}$ & $\begin{array}{r}2,090 \\
652 \\
585\end{array}$ & $\begin{array}{r}1,994 \\
644 \\
546\end{array}$ & $\begin{array}{r}1,871 \\
630 \\
532\end{array}$ & $\begin{array}{r}1,923 \\
665 \\
473\end{array}$ & $\begin{array}{r}1,976 \\
662 \\
494\end{array}$ & \\
\hline \multicolumn{10}{|l|}{ By type of school: } \\
\hline Students in day schools (thousands) & 1,538 & 1,515 & 1,500 & 1,442 & 1,398 & 1,324 & 1,377 & 1,434 & \\
\hline Students in night schools (thousands) & 184 & 164 & 142 & 116 & 98 & 90 & 91 & 90 & \\
\hline Correspondent students (thousands) & 617 & 592 & 560 & 532 & 497 & 457 & 455 & $45:$ & \\
\hline \multicolumn{10}{|l|}{ By specialty: } \\
\hline Industry and construction & 907 & 865 & 813 & 764 & 746 & 724 & 771 & 812 & \\
\hline Agriculture & 317 & 302 & 296 & 290 & 287 & 260 & 254 & 253 & \\
\hline Transport and communications & 196 & 188 & 178 & 169 & 105 & 157 & 166 & 170 & \\
\hline Economics and law & 224 & 216 & 210 & 215 & 206 & 188 & 195 & 196 & \\
\hline Healthcare, physical culture and sport & 306 & 309 & 312 & 277 & 239 & 210 & 214 & 224 & \\
\hline Education & 338 & 341 & 343 & 322 & 301 & 283 & 269 & 267 & \\
\hline Art and cinematography & $5 l$ & so & $\$ 1$ & 53 & 50 & 49 & 55 & 53 & \\
\hline
\end{tabular}

Hourees end Hetes:

Number of PTUs, students, students accepted, and graduates: Goskomstat Rossii, Rossiyskiy statisticheskiy yezhegodnik, 1997, p 199

Number of teachers in PTUs: Ministry of Education of Russia, Statisticheskiye dannyye po sisteme obrazovaniya, 1998 The specific term used is 'pedigogicheskiy kadre'

Number of institutions and students of specialized secondary institutions: Goskomstat Rossii, Rossiyskiy statisticheskiy yezhegodnik, 1997, p 201-202

Not avallable

\section{Annex C4: Selected Data on Higher Educational Institutions in Russia, 1989-1997}

\begin{tabular}{|c|c|c|c|c|c|c|c|c|}
\hline & 1989 & 1990 & 1991 & 1992 & 1993 & 1994 & 1995 & $\overline{1996}$ \\
\hline Number of higher educational institutions (HEIs) & 512 & 514 & 519 & 535 & 548 & 553 & 569 & 573 \\
\hline Number of students in HEIs, total (thousands) & 2,861 & 2,824 & 2,763 & 2,638 & 2,543 & 2,534 & 2,655 & 2,801 \\
\hline Students in day schools (thousands) & 1,624 & 1,647 & 1,668 & 1,658 & 1,624 & 1,629 & 1,700 & 1,777 \\
\hline Students in night schools (thousands) & 311 & 285 & 250 & 202 & 170 & 159 & 161 & 163 \\
\hline Correspondent students (thousands) & 926 & 892 & 845 & 777 & 748 & 747 & 795 & 861 \\
\hline \multicolumn{9}{|l|}{ By field of study: } \\
\hline Humanities & .. & .. & .. & .. & 242 & 231 & 265 & 284 \\
\hline Social and behavioral sciences & .. & .. & .. & .. & 270 & 248 & 321 & 373 \\
\hline Natural sciences & .. & .. & .. & .. & 152 & 140 & 138 & 140 \\
\hline Medical science & .. & .. & .. & .. & 180 & 167 & 163 & 157 \\
\hline Engineering & .. & .. & .. & .. & 830 & 787 & 781 & 799 \\
\hline Other & .. & .. & .. & .. & 869 & 960 & 1,122 & 1,212 \\
\hline Number of universities & 40 & 42 & 48 & 52 & 57 & 72 & 75 & 81 \\
\hline Number of students in universities & 309 & 328 & 382 & 390 & 393 & 508 & 522 & 590 \\
\hline Number of students accepted into HEIs (thousands) & 603 & 584 & 566 & 521 & 544 & 568 & 629 & 674 \\
\hline Number of graduates from HEIs (thousands) & 433 & 401 & 407 & 425 & 444 & 407 & 396 & 415 \\
\hline \multicolumn{9}{|l|}{ By specialty: } \\
\hline Industry and construction & 162 & 145 & 145 & 155 & 164 & 145 & 133 & 137 \\
\hline Agriculture & 38 & 36 & 36 & 35 & 41 & 31 & 31 & 34 \\
\hline Transport and communications & 22 & 19 & 21 & 22 & 22 & 19 & 17 & 18 \\
\hline Economics and law & 38 & 38 & 39 & 35 & 30 & 33 & 36 & 39 \\
\hline Healthcare, physical culture and sport & 32 & 28 & 29 & 34 & 33 & 34 & 31 & 33 \\
\hline Education & 138 & 132 & 134 & 141 & 149 & 142 & 143 & 150 \\
\hline Art and cinematograplyy & 4 & 4 & 4 & 4 & 4 & 3 & 5 & 5 \\
\hline Number of private HEIs & .. & .. & .. & .. & .. & 157 & 193 & 244 \\
\hline Number of students in private HEIs (thousands) & .. & .. & .. & .. & .. & 111 & 136 & 163 \\
\hline As sirare of all students in HEls & .. &.. & .. & .. & .. & 4.2 & 4.9 & 5.5 \\
\hline
\end{tabular}

Sources and noles:

Number of higher educational institutions and universities and students: Goskomstat Rossii, Rossiyskiy statisticheskiy yezhe godnik, 1997, pp. $207-215$.

Number of students by field of study: UNICEF, TRANSMONEE Database.

Number of private HEls: Goskomstat Rossii, Rossiyskiy statisticheskiy yezhegodnik, 1997, pp. 207-215.

. Not available. 
Annex C5: Selected Data on Private Schools in Russia, 1989-1997

\begin{tabular}{|c|c|c|c|c|c|c|c|c|c|}
\hline \multicolumn{10}{|l|}{ Pre-schools } \\
\hline Number of private pre-schools & .. &.. &.. & .. & 10,856 & 8,016 & 6,236 & 4,958 & .. \\
\hline Share of total (percent) & .. &.. & .. & .. & 13.9 & 11.0 & 9.1 & 7.7 & .. \\
\hline Capacity in private pre-schoois & .. & .. &.. & .. & 638,253 & 306,750 & 380,855 & 321.548 & .. \\
\hline Share of total (percent) &.. & .. &.. & .. & 8.5 & 4.4 & 5.7 & 5.1 & .. \\
\hline \multicolumn{10}{|l|}{ Primary education (classes $1-4$ ) } \\
\hline Number of private schools & & & & & 112 & 124 & 141 & 119 & .. \\
\hline Share of total (percent) & & & & & 0.6 & 0.7 & 0.8 & 0.7 & .. \\
\hline Students in private schools & .. &.. &.. &.. & 17,123 & 20,369 & 22,783 & 21,245 & .. \\
\hline Share of total (percent) & .. & .. & .. & .. & 0.2 & 0.3 & 0.3 & 0.3 & .. \\
\hline \multicolumn{10}{|l|}{ Lower secondary (classes 5-9) } \\
\hline Number of private schools & & & & & 36 & 34 & 83 & 107 & .. \\
\hline Share of total (percent) & & & & & 0.3 & 0.2 & 0.6 & 0.8 & .. \\
\hline Students in private schools & .. & .. &. &.. & 11,194 & 14,058 & 17,285 & 18,999 & .. \\
\hline Share of total (percent) &.. & .. & .. &.. & 0.1 & 0.1 & 0.2 & 0.2 & .. \\
\hline \multicolumn{10}{|l|}{ Upper secondary (classes 10-12) } \\
\hline Number of private schools &.. &.. & .. &.. & 220 & 289 & 301 & 314 & $\ldots$ \\
\hline Share of total (percent) & .. & .. & .. & .. & 0.6 & 0.8 & 0.8 & 0.9 & .. \\
\hline Students in private schools & .. & .. & .. & .. & 4,309 & 5,076 & 5,732 & 6,617 & .. \\
\hline Share of total (percent) & .. & .. & .. & .. & 0.2 & 0.3 & 0.3 & 0.3 & .. \\
\hline Number of gymasia & .. & .. & 77 & 200 & .328 & 433 & 482 & 536 & 627 \\
\hline Number of lycea & .. & .. & 100 & 306 & 569 & 727 & 800 & 885 & 979 \\
\hline Number of students in gymnasia & .. & $\therefore$ & 49,500 & 116,900 & 214,500 & 284,200 & 331,700 & 372,800 & 426,000 \\
\hline Number of students in lycea & .. & .. & 78,600 & 234,800 & 433,200 & 553,000 & 641,200 & 715,100 & 793,000 \\
\hline \multicolumn{10}{|l|}{ Upper secondary, vocational } \\
\hline Students in private schools & 4,346 & 4,328 & 4,321 & 4,269 & 4,273 & 4,203 & 4,166 & 4,114 & 4,050 \\
\hline Share of total (percent) & 0.2 & 0.2 & 0.2 & 0.2 & 0.2 & 0.2 & 0.2 & 0.2 & 0.2 \\
\hline \multicolumn{10}{|l|}{ Teltiary, non-university degree } \\
\hline Students in private schools & .. &.. & .. & .. & .. & .. & 6,607 & 10,510 & 16,403 \\
\hline Share of total (percent) & .. & .. & .. & .. & .. & .. & 0.3 & 0.5 & 0.8 \\
\hline \multicolumn{10}{|l|}{ Tentiary, university degree } \\
\hline Number of private HEls & .. & .. & .. & .. & .. & 157 & 193 & 244 & \\
\hline Students in private schools & .. & .. & .. & .. & 69,333 & 110,551 & 135,486 & 162,544 & 201,829 \\
\hline Share of total (percent) & .. & .. & .. & .. & 2.7 & 4.2 & 4.9 & 5.5 & 6.2 \\
\hline Number of pedagogical workers in private schools & .. & .. & .. &.. & 9,200 & 11,600 & 13,800 & 14,600 & . \\
\hline Share of total (percent) & .. & .. & .. &. &.. & 0.8 & 0.9 & 0.9 & .. \\
\hline
\end{tabular}

Sources amd notes:

Pre-schools, primary, and secondary: UNICEF, TRANSMONEE Database

Number of private schools: Goskomstat Rossii, Rossiyskiy statisticheskiy yezhegoduik, 1997, pp. 194

Number of gymuasia and lycea and students in each: Ministry of Education of Russia, Statisticheskiye damnye po sisteme abrazovaniya,

UPPer secondary, vocational: UNICEF, TRANSMONEE Database.

Number of private HEIs: Goskomstat Rossii, Rossiyskiy statisticheskiy yezhegodnik, 1997, pp. 207-215.

Teltiary, university and non-university: UNICEF, TRANSMONEE Database.

Not available. 
Annex C6: Share of Household Expenditures on Education by Year and Income Decile

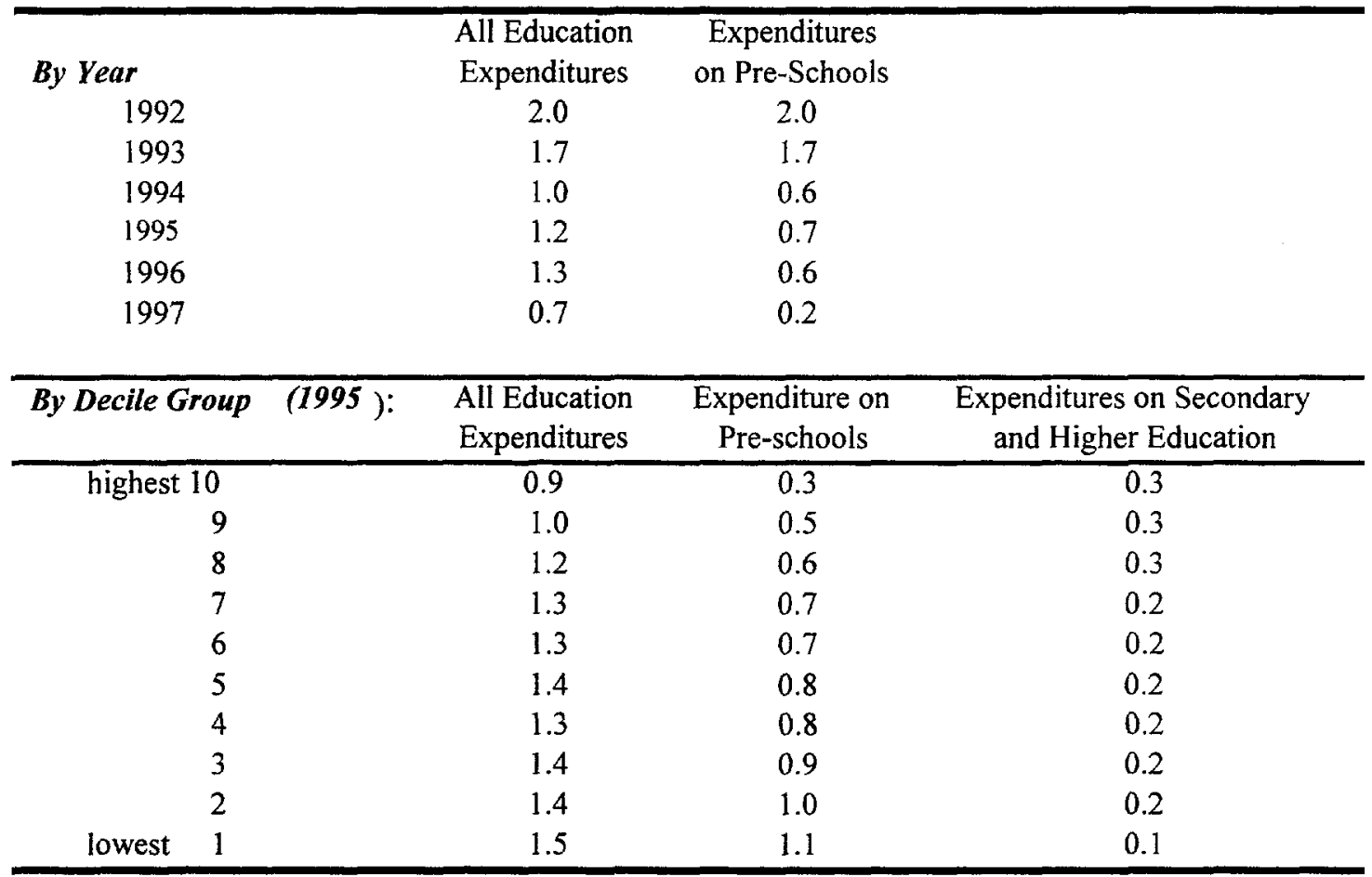

Sources and notes:

Goskomstat Rossii, Uroven'zhizni naseleniya Rossii: statisticheskiy sbormujm 1996; Goskmostat Rossii, Rossiyskiy statisticheskiy yezhegodnik, 1997; and Goskomstat Rossii, Rossiya v tsifrakh: kratkiy statisti cheskiy sbornik, 1998. 


\section{ANNEX D: SAMARA REGION}

\section{Characteristics of the Region}

During Russia's transition to a market economy, a handful of regions appear to have been able to leverage their advantages, based principally on natural resources, location and industrial infrastructure, and to combine these with reformist policies so as to emerge as "winners" in the transition. Samara Oblast, located on the lower Volga, is one of this relatively small group of Russian regions. Samara was one of only seven net donors to the federal budget in 1996. Despite these net transfers from the region, Samara still has sufficient fiscal resources to afford spending on social programs not possible for many less prosperous regions, a fact that impacts significantly and positively on the 3.3 million persons living in the region.

The oblast center of Samara city, with 1.2 million persons, is the sixth largest city in the country. Thirty-six percent of the oblast's population live in the city of Samara. The second largest city in the region, Tolyatti, home to the AvtoVAZ automobile plant, is located only 70 kilometers away, making the region quite unusual in having two sizable urban centers so close to one other. About 60 percent of the oblast's population live in these two urban areas combined. Overall, the region is more urbanized than Russia as a whole, with 81 percent of the population living in urban areas as opposed to 73 percent in the entire country.

Samara is administratively divided into 11 cities and 27 rural rayon's, and it is through these units that the oblast administration reaches the constituent parts. Because of its large size, the city of Samara is further divided into 12 urban rayon's. Similar to the system of financial transfers and equalization mechanisms between the federal government and the 89 oblast-level units in Russia, there is a system of fiscal transfers and various equalization mechanisms within many of the subjects of the federation, including Samara. More will be discussed regarding this later, but as for Russia as a whole, within Samara there are a few 'donor' units while the majority are 'recipient' units.

Between the 1989 population census and 1997, Samara's population has grown a modest 1.4 percent, which is slightly higher than the overall rate for Russia (only 0.1 percent). Like other regions in western Russian, deaths have exceeded births over this period, but there has been positive migration -- net in-migration has exceeded the negative natural increase, producing the moderate population increase.

Samara's age-sex pyramid is similar to that of Russia as a whole (see figure 2.2). In both the effects of the declining birth rates and rising death rates will have an effect on the educational system over the next generation. While Samara's population as a whole is expected to rise moderately between now and 2010, the number of school-age children is expected to decline. There will be declining demand on educational services as this reduced cohort, now just beginning to enter the primary grades, moves its way through the educational system. 
The region's economic prosperity is reflected clearly in the fact that its gross regional product $(13,612$ thousand Rbls per capita in 1995) is 42 percent higher than the national average and by far the highest in the Volga region, in which Samara is located. It is difficult to determine the veracity of poverty measures in Russia, but if they are any indication, the percent of the population living below the poverty line in Samara is lower than the national average. In Samara, 20.1 percent of the population had incomes below the subsistence minimum in 1996 versus 22.0 percent for the entire country.

The overall economic situation of the region has contributed to a strong budget. In 1996, the region sent 47 percent of its consolidated tax receipts to the federal budget. Only 1 percent of revenues were in the form of federal transfers. The overall budget deficit was 1.9 percent in 1996, and this was financed with bank loans rather than federal government credits. The region planned to issue $\$ 500$ million in Eurobonds in either 1997 or 1998 , to be used for investment rather than deficit financing. There are few Russian regions that are currently allowed by federal authorities to do so. In sum, the overall strong economic and fiscal situation gives Samara greater flexibility and more autonomy than most, less prosperous regions of the country to finance social programs, including those in education.

\section{Reforms to Reduce Per Student Costs}

Senior Education Administration staff of Samara Region have concluded that the root causes of recent unfavorable staffing ratios and high per-student costs were threefold: (1) the formula by which the Oblast was allocating budget to schools, (2) the fungibility of oblast subventions to raions, whereby raions were free to divert allocations intended for education to use in other sectors, and (3) the small size of many schools, especially those in very rural and remote parts of the region. These three causes are, in fact, closely inter-related, and Samara has introduced a program of inter-related reforms intended to address the underlying problems individually and in combination. As would be expected, implementation of several of the reforms will involve considerable up-front investments. These costs have been carefully identified and quantified, as have been the savings expected in the future, and how the savings will be used to increase learning achievement and to maintain or improve Samara's already high levels of access. Full implementation of all aspects of the reform program will continue well into the next decade, but several significant changes were introduced at the start of the 1998 budget cycle.

The administration's assessment of the traditional system of education finance in Samara (which would be found as well in most other parts of the Russian Federation) is that public financing was "supporting the process but not the results" of education and training. The level of financing going to an individual school in the Region was more a reflection of history than of rational choice based on a consideration of economic trade-offs. Schools which, for historical reasons (e.g., many subjects taught), happened to have large numbers of teachers and other staff relative to the number of students currently enrolled would continue to receive larger allocations than schools with fewer staff. In many rural schools, classes of 5-to-10 students were not uncommon, even when a school was close to a much larger school in the central town of the raion. The Samara Education Administration rightly concluded that such staffing allocations were not sustainable in today's resource constrained environment. Given that the consolidated budget of the Oblast had been contracting, staff salaries had been growing as a proportion of the total budget for education, especially given that federal regulations require salaries and benefits of employed staff to be paid first, as two of the three "mandated" expenditure items in education (the third being meals for students in subsidized food programs). 
Table D1 Samara, Selected Education Indicators, 1990-1997

\begin{tabular}{|c|c|c|c|c|c|c|c|c|}
\hline & 1990 & 1991 & 1992 & 1993 & 1994 & 1995 & 1996 & 1997 \\
\hline Number of school-age children $(0-16)$ & 766.6 & & & & & $7: 2.7$ & & 6815 \\
\hline School-age children as share of total & 235 & & & & & & & 206 \\
\hline \multicolumn{9}{|l|}{ I're'-ichomis } \\
\hline Number of schools & 1571 & 1579 & 1508 & & 1344 & 1318 & & \\
\hline Nunber of places (thousands) & & 1704 & & & 1464 & 1479 & & \\
\hline Number of students (thousands) & 1903 & 179.1 & 1542 & . & 132,4 & 124 & & \\
\hline \multicolumn{9}{|l|}{ Number of taachers } \\
\hline Student-teacher ratio & & & & & & & & \\
\hline Enrolfment ratio & 667 & 648 & 581 & 582 & 578 & 583 & & \\
\hline \multicolumn{9}{|l|}{ C'mupmlsary schoois } \\
\hline Number of schools & 1164 & 1163 & 1164 & 1177 & 1166 & 1110 & & \\
\hline Number of students (thousands) & 423 & $42 !$ & 425 & 432 & 446 & 457 & & \\
\hline Percent on second shift & 23.3 & 248 & 245 & 264 & 271 & $27 !$ & & \\
\hline Number employed in education (thousands) & & .. & & & & & & \\
\hline Number of teachers (thousands) & 289 & & 316 & & 337 & 354 & & \\
\hline Percent teachers in education & & & & & & & & \\
\hline Student-teacher ratio & 146 & & 134 & & 132 & 129 & & \\
\hline Enrollment ratio & & & & & & & & \\
\hline \multicolumn{9}{|l|}{ Spocialized secondary schosis } \\
\hline Number of schools & 61 & & 61 & & 61 & 62 & 62 & 64 \\
\hline Number of students (thousands) & 566 & 558 & 521 & 531 & 485 & 519 & 53 & 538 \\
\hline \multirow{2}{*}{\multicolumn{9}{|c|}{$\begin{array}{l}\text { Number of teachers } \\
\text { Student-teacher ratio }\end{array}$}} \\
\hline & & & & & & & & \\
\hline Enrollment ratio & & .. & & & & & . & \\
\hline \multicolumn{9}{|l|}{ Migher educational insituturons } \\
\hline Number of schools & 12 & & 12 & & 13 & 13 & 13 & 14 \\
\hline Number of students (thousands) & 749 & 73.4 & 698 & 657 & 544 & 664 & & 72308 \\
\hline \multicolumn{9}{|l|}{ Fducation finame' indicators } \\
\hline \multicolumn{9}{|l|}{ Total public expenditures on education (million nubles) } \\
\hline \multicolumn{9}{|l|}{$\begin{array}{l}\text { Salaries (percent) } \\
\text { Medicine (percent) }\end{array}$} \\
\hline Medicine (percent) & & & & & & & & \\
\hline \multicolumn{9}{|l|}{ Meals (percent) } \\
\hline \multicolumn{9}{|l|}{ Capital investment (percent) } \\
\hline Civil works (percent) & . & & & & & & & \\
\hline Other (percent) & . & .. & & & & & & \\
\hline Education expenditures as a share of consolidated budget (percent & & & & & & & & \\
\hline Average wage in education as percent of average oblast wage & & & & & & & & \\
\hline
\end{tabular}

Simreces and notes.

Goskomstat Rossi, Regiony Rossii, 1997, Goskomstat Samara, Zhenshchiny i deti Samarskoy oblasti, 1996: Goskomstat Rossii, Rossiyskiy statisticheskiy yezhegodnik, 1996

The number of school-age children given for 1990 are actually for 1989

Not available

\section{Normative Financing}

Starting with 1998, Samara has introduced, on a trial basis, a new funding formula for the allocation of oblast subventions given for education to receiving raions in the Region. Samara refers to this new system as "normative financing," essentially a capitation system whereby "money follows students." Oblast allocations will now be based on the number of students enrolled in each raion, with some differences to reflect factors known to affect per-student costs: (1) the level of education (e.g., more for higher grades than for lower), (2) the type of education (more for vocational than for general, and more for lyceums and gymnasiums than for regular compulsory schools), and the extent to which a raion is either rural or urban (rural teachers will continue to receive a 25 -percent supplement on top of their base salaries, as well as rent-free housing wherever this can be provided).

Presumably, the raion education administrations will allocate their own budgets (whatever is spent on education from the raion's own tax revenues plus transfers, if any, from the regional budget) according to much the same formula. However, a precept of Samara's financing reform is that school directors should be given maximum freedom to decide how to use the school's resources, including the larger share that will continue, in most instances, to come from the budget of the raion (the rest coming from the school's own revenues -- received for "additional 
education" and for other goods and services sold to clients). In theory, a school director will be free to choose how many teachers, administrators and support staff are needed, and free to substitute more textbooks, teaching materials and computers for some staff now employed by the school.

An inevitable consequence of normative financing in Samara will be some reductions in overall staffing, both because some educational institutions will no longer receive enough budget from the raion to support all staff currently on the payroll and because some school directors will decide that more money is needed for non-salary inputs in order to achieve better results. The Education Administration of Samara believes that the adjustment to lower staffing levels will be relatively painless, for the reason that many schools make use of part-time staff, whose contracts are year-to-year, and because there are many "pensioners" (i.e., teachers past retirement age, who are already receiving full pensions in addition to their current salaries) now teaching in Samara. It is estimated that $10 \%$ of those teaching are pensioners who could be let go on short notice. As for part-time teachers, many of these are "moon-lighting" university lecturers. In particular, the lyceums and gymnasiums, which have close ties to particular higher education institutions, make use of university staff on a part-time basis. The Head of Samara's Education Committee believes that university lecturers do not always make good teachers in compulsory education, since optimal teaching methods may be quite different at different levels of education.

There is some danger that reduced staffing induced by the introduction of normative financing in Samara will bring some schools into violation of federal laws, which, for example, require all classes to be no larger than 25 students (even when the teaching of a particular subject at a particular level of education might call for different teaching methods-- for example, larger lecture classes in order to finance higher levels of non-teacher inputs). Naturally, Samara is concerned about this and will make every effort to ensure that schools comply with federal laws.

\section{Centralized Financing}

A second change introduced in Samara Region in 1998 amounts to an earmarking of oblast subventions transferred to receiving raions and intended for education. The new system of "centralized financing" does not apply to "donor" raions (for example, Samara, the capital city of the Oblast), which receive nothing back from the tax revenues (principally Value Added Tax revenues) that they collect and transfer up to the Oblast according to the agreed principles of revenue sharing within the Russian Federation. For receiving raions, on the other hand, the new system marks a significant change. In the past, oblast allocations to raions in the Region amounted to block grants, which could then be re-allocated across sectors however raion administrators decided. There was a growing concern, however, at the oblast level and within the education sector that some raions were diverting resources and increasing the local support for other services at the expense of education.

Under the new system of centralized education financing, oblast allocations for compulsory education pass through the raion administrations, but they are not shown as raion-level expenditures. Thus, for example, in Koshkinsky Raion (a receiving Raion in Samara on which budget information was collected as part of this study), the Raion budget for education appears to have fallen from an actual figure of 14.2 (millions of new Rbls) in 1997 to a budgeted figure of 3.3 in 1998. This drop, however, is an illusion. The expenditure of 14.2 in 1977 was, in fact, financed by a combination of revenues raised locally, on the one hand, and transfers from the Oblast to the Raion, on the other hand, whereas the 3.3 shown in the Raion budget for education in 1998 refers only to locally financed expenditures on education. Another 14.9 (making a total 
of 18.2 planned for 1998) will be financed from the regional budget. These subventions will be transferred to the Raion Administration but will be earmarked for education.

The new system, therefore, restricts the freedom of choice of receiving raions as compared with the old system. At the same time, however, the new system of centralized financing will extend the flexibility that raions have, and in particular, the flexibility that school directors have to spend education budgets however they may wish - so long as they spend this money on education. Consistent with the principles of normative financing, described above, the new system will allow (indeed, it will encourage) each school director to decide how much is spent on salaries and how much on other inputs so as to maximize the school's "output" as defined by the school's mission and/or as dictated by the school's "clients" (students, their families, and ultimately the labor market). The only regulation that will restrict a director's choice set will be the federal law requiring that the salaries and benefits of employed staff be paid first, before anything else.

Some people may argue that this earmarking of funds is inconsistent with one of the key advantages of decentralization, which is to augment local choice. Nevertheless, the Samara reform is an interesting compromise that both "gives something" and "takes something away" from participating raions. Samara's reform is one that should be monitored and evaluated, with an eye to its replication in the future in other regions. Under the new system, raions will no longer be able to divert oblast financing to other sectors, nor to postpone the payment of teachers' salaries (thereby reducing salaries in real terms, especially during periods of high inflation). The apparent objective of Samara's reform is to balance the advantages of decision making at the local level, on the one hand, with the need to ensure adequate expenditure in the critically important area of compulsory education, on the other. Earmarking, in effect, raises the power of the Oblast Administration over programs at the raion level One should hope that the precedent set in education will not be copied by all other sectors, in which case raion-level decision making will have been seriously undermined, at least in the case of very poor raions. In the extreme, such raions become little more than the tax collectors and the bankers of tax revenues controlled by the Oblast Administration.

\section{Rationalization of Small Schools}

A third reform planned by Samara to enhance the efficiency of delivery of compulsory education in the Region will take several years to implement. It will require considerable upfront investment outlays, which a poorer and less far-sighted oblast might find difficult, if not impossible, to finance. This third "reform" is, in fact, a program of inter-related reforms, which have been carefully conceived and costed, and whose implementation will require close coordination and the cooperation of several sectors of the Oblast Administration. As such, this is a program that could not be undertaken easily in a different oblast by an education head of department who was acting in isolation from the rest of the administration. It would be difficult without a strong governor, who is convinced of the long-run advantages of the reform program for the region, and without the endorsement of the regional Duma.

The key element of Samara's program of school rationalization is the creation of school clusters in order to achieve larger class groups so as to benefit from economies of scale in education. Although small schools containing uneconomically small classes are common in rural Samara, the Education Administration notes that few rural schools are more than 25 kilometers away from the nearest town center, and most are much closer than this. The Samara Administration has decided that village schools are needed in the earliest years of education, i.e., through grades 3 or 4 , and should be maintained in order to ensure equitable access for poor rural 
families, even when this results in small class groups. From about the age of 10 , however, children are old enough that they can attend schools further from home, even if this means an hour each way on a school bus. ${ }^{38}$

\section{Reforms in the Training, Recruitment, and Compensation of Teachers}

Teachers pay and conditions in Samara Region mirror fairly closely those in the rest of Russia. $^{39}$ As noted above, the average teaching load of 18 hours is usually increased to about 25 hours. Salaries are marginally increased by small allowances paid for extra levels of certification (about $50 \mathrm{Rbls}$ a month per level of certification), and they are $25 \%$ higher in rural areas. In addition, rural teachers also receive free accommodation. Over the past six years, teacher numbers have grown by $33 \%$ whereas the number of students has grown by only $7 \%$. The increase in numbers is explained by the needs of rural schools. However, while rural schools remain overstaffed in the conventional sense, urban schools are often overcrowded with schools running double shifts in many cases.

\section{Teacher Training and Re-training}

Expenditure on teacher training in Samara has more than doubled over the last few years (6.9 million Rbls in 1995 as compared with 14.2 in 1997). However, the share of the education budget for teacher training remains fixed at $0.68 \%$. Students enter one of the 7 pedagogical colleges in Samara after 9-11 years of compulsory schooling. ${ }^{40}$ Those who have studied for 9 years are required to undertake four years of teacher training, while those with 11 years of schools take only two and a half years. Ninety percent of graduates from the pedagogical colleges work as teachers or as social workers. It seems that many teachers who return to work in rural areas do not continue beyond the level of pedagogical colleges and do not take higher university degrees. It also appears that $35 \%$ of those entering the teacher training colleges are

Russian reactions to the first version of this report was strong in rejecting the closure of rural schools and introduction of bussing. In Samara, the maximum distance between villages and planned central schools, for pupils from age 10 upwards, would be about 15 kilometers. Arguments against this proposal include references to the climate, condition of the roads and the needs of some families to have children help with chores in the mornings and evenings. If bussing is not acceptable in other parts of the RF, "alternative technologies" for delivering education services should be considered. Multi-grade teaching, for example, is found in Russia, including in Samara, but it tends to be viewed as a "necessary evil" and something to be phased out as soon as budget allows. In fact, the research literature from elsewhere suggests that multi-grade teaching may be the most cost-effective way of delivering quality education in sparsely populated settings, especially when the savings in teachers' salaries and the related possibility of creating a richer learning environment are taken into account. Mixed-age students learn from one another, and it may be easier for children of differing abilities to progress at their own pace than it is in a traditional, single-grade class. Of course, good multi-grade teaching requires special teacher preparation, and rural teachers are often the least experienced and least well-equipped to master the special teaching methods required.

39 Of the 32,000 teachers in Samara Region, $92 \%$ are female. The average age is quite young, 35 years, but despite this, about $10 \%$ of the teaching force is beyond retirement age. The average salary in education in 1997 was 666 rubles per month, about 60 percent that of the average for the region.

40 Two of these colleges are in Samara City, and the third, in a village, specializes in training for rural schools. Pedagogical College \#2 in Samara City, founded in 1984 , has an operating budget of $\$ 438,000$, of which roughly $20 \%(\$ 87,000)$ is derived from paid courses. Nearly $45 \%(\$ 188,000)$ of the budget goes for salaries. The financing norm for this college is 3,521 New Rubles per student per year. The plan allows for about 550 students, but 600 were actually enrolled in 1998. As the demand for teachers declines, pedagogical colleges are introducing new specializations, such as training for social workers, paid courses for part-time students and preparation courses for entry into higher education. A reduction in enrollments for prospective teachers is underway in several colleges. 
recruited from rural areas, even though rural areas account for only $19 \%$ of the total population. There is evidence of positive discrimination in terms of recruiting teacher trainees -- those from rural areas are admitted to colleges through a more lenient entry examination. This entrance policy, combined with higher salaries and free teacher accommodations in villages, constitutes a package of positive incentives to attract rural individuals to enter teaching and to remain as teachers in rural areas.

Samara uses an approach for teacher re-training different from other regions visited in Russia. Teachers are given vouchers for in-service training. The vouchers are good for up to 240 hours of training every five years. ${ }^{41}$ They can be used for different subjects, and teachers have the choice of the type of courses they wish to take and where they wish to take it (i.e., at the pedagogical university or in some other institution). Currently, Samara is negotiating with other regions, including the eight other oblasts of the Greater Volga Region, to involve them in the voucher system and to allow teachers from all of the ten oblasts to receive teacher training in any of the oblasts.

\section{Teachers Contracts to Enhance Teacher Productivity}

There is an interesting initiative relating to teachers' contracts in the city of Syzran in the far west of Samara Region. The local administration has developed a scheme to pay teachers for each course taught, rather than for the number of hours worked. Part of the plan, implemented on a pilot basis in 1998, will be to assign teachers to work only for certain school levels (e.g., 4-6 grades) and to focus on effective/efficient teaching and to achieve greater specialization of teaching at these levels. Within the scheme, teachers will be able to teach for as many or as few hours as they wish, and they will be encouraged to think about using other technologies for delivering student learning. Fixed-price contracts will be agreed between the education administrators and individual teachers, and fulfillment of contract will be assessed by the examination results of pupils.

While this approach to efficiency is very innovative, it has not yet been endorsed by teachers themselves. It is doubtful whether it will be acceptable to many, not just because of increased uncertainty over payment, but also because there are pedagogical issues involved. Linking education results so directly to the teaching process ignores complex issues of individual learning ability as well as the physical and psychological circumstances of both pupils and teachers.

\section{Textbook Provision to Enhance Quality}

As part of its program to adapt its education system to market conditions, Samara has developed its own textbook procurement program, already (in early 1998) signed by the Governor but not yet ratified by the Regional Duma. The objective of the program is to ensure a choice of books in all school subjects. In order to resolve procurement and distribution problems, Samara's Education Administration has contracted a company (Samara Innovation Company) to purchase textbooks from the Federal List. So far there have been some minimal delays in payment by the Administration, but on balance, the Managing Director reckons that his risk is negligible, as his client is the Regional Government. By using this purchasing method, the Administration asserts that the average prices of most textbooks delivered to Samara are among the cheapest in Russia. The Oblast Education Administration finances only books from the Federal List. There is some

41

The federal norm for teacher retraining is 140 hours every five years 
additional funding of books at the municipal level. The estimated price of a set of textbooks is between 100 and 150 New Rbls per year, depending on the grade level. ${ }^{42}$

At the beginning of March, children get the list of books that they must have acquired by the following September. Parents can purchase books in a range of retail outlets with which the distribution company has supply contracts. Textbooks are free of charge in rural raions, and there is a scheme to target poorer families in cities and towns who will receive free access to textbooks. Libraries purchase books for use by those who cannot afford them (an estimated 30\% of the population will get them on long loan from the libraries).

In addition to the federal textbook purchasing program, the Administration supports additional publishing innovations, such as the development of essential new textbooks and teaching materials for the Regional Education Component. A number of titles have been published through the Regional Teacher Training Institute in such subjects as civics, law and economics, providing extra options for schools and teachers. Some of these books are marketed outside the Greater Volga Region and are sold, for example, in Sakhalin and Dagestan.

Samara is also one of the pioneer oblasts in Russia in establishing an Information Center on textbooks and related materials. The information available in the Center is targeted to teachers and education administrators, although anyone (e.g., parents or students) can access it. Soon the Information Center will have a web page which will make it accessible to a larger audience.

\section{Reform of Vocational Education to Reduce Unit Costs and Increase Market Relevance}

Like the rest of the RF, Samara has inherited a largely obsolete system of vocational education, developed in earlier times to meet the manpower needs of a centrally planned economy. In Samara's case, vocational education was especially related to the needs of the military. This system was quite inflexible and offered training for narrow specializations that have become increasingly irrelevant in today's labor market.

There are 78 primary vocational education institutions (PTUs) in Samara with an approximate enrollment of 35,000 students and 65 secondary vocational education institutions (technikums) with an enrollment of 63,000. In most, though not all, cases, these institutions remain very inefficient, with outdated, supply-driven specializations, small class sizes and most teachers having been trained to prepare students for the command economy. The vocational education system is further burdened with large overheads, including cumbersome buildings that are difficult to heat, and with much of the available equipment quite outdated. Economies of scale are difficult to achieve in vocational education in rural raions where one PTU must serve the needs of all students in the area. Particular difficulties arise in trying to provide training tailored to the needs of the agricultural sector. Unit costs remain twice as high as in general education, with the annual cost of training one student in a PTU being about 3,500-5,000 Rbls $(\$ 600-\$ 800)$. There is a $90 \%$ job placement rate from the PTUs, which may account for the application rate of 2 applicants for every one place. However, anecdotal evidence suggests that many graduates are dissatisfied with their salaries and conditions of work. Furthermore, it appears that many students get jobs unrelated to their training.

42 Region wide estimates for the cost of a set of textbooks are: Grades 1-3, 100 Rbls; Grade 4, 120 Rbls; Grades 5 7, $135 \mathrm{Rbls}$; Grades 8-9, 145 Rbls; Grades 10-11, 150 Rbls. The maximum price quoted was a ceiling of 200 Rbls for Grades 10-11. 
Change is underway, however, most notably in the system of financing first level vocational education and in the governance of some PTUs and technikums. Samara is one of four regions in RF that have taken over, from the Federal Government, according to a decree of January 20,1997 , full responsibility for managing its primary system of vocational education ( 78 PTUs). ${ }^{43}$ The advantage of having the regions assume this responsibility is that the Regional Education Administrations can now begin to initiate the necessary structural and financing reforms necessary to orient the system to the local labor market and student needs.

Samara Region is beginning the introduction of these reforms. Among changes planned or already underway are:

- an increase in student-teacher ratios, from the present norm of $8: 1$ to at least $25: 1$

- the introduction of new specializations regionwide

- the merging of some primary level institutions -- The overall number of PTUs in Samara was to decrease from 78 to 69 by the end of 1998 . It is estimated that there will be significant savings from these mergers since, according to the Regional Education Administration, a PTU with an enrollment of 200 students has unit costs twice that of a similar institution with 600 students. However, accomplishing this objective will be difficult because of large, inefficient buildings and old, outdated equipment, as well the number of staff redundancies that will be created. An example of an institution struggling with these problems, visited by the study team, is PTU \#17 in Syzran.

- the transfer of governance of vocational education institutions from various line ministries to the Ministry of General and Professional Education

- the integration of primary and secondary vocational education under a single structure with two levels -- This has occurred already, for example, in the Samara College of Hairdressing and Fashion.

- the introduction of changes to promote flexibility in existing institutions including, inter alia, the promotion of revenue generation schemes and encouragement for vocational education institutions to open their own bank accounts. The study team saw this, for example, at PTU \# 59 in Tolyatti.

\section{Special Education Service}

In addition to the normal range of primary, secondary, vocational, and teacher training institutions, Samara offers a wide range of educational services for socially deprived children such as orphans, for children with special needs including the gifted, and for those who are willing to pay for special services.

In the former system, orphans, as well as children with physical or psychological problems, even minor learning difficulties, tended to be isolated and "hidden." The current policy of Samara Region is, to the extent possible, to keep these children part of normal family life and to integrate them into the general education system. In addition to those children whose parents are deceased, there are many "social orphans" in Samara, whose parents may be ill, destitute or in prison. The first step for the orphanages set up to teach and now to care for such children will be to encourage alternative, foster-care arrangements in private homes. This could result in significant savings in what Samara now spends on public orphanage services (see Box illustrating high costs of an orphanage in Syzran). To date, 2,000 children have been adopted in Samara.

43 The other three regions are Novgorod Viliki, Nizny Novgorod and Leningrad. 


\section{Box D1: Syzran Orphanage}

The study team visited a very well-run, but also expensive, orphanage in Syzran City. At the time of the visit, the orphanage had 67 children and 85 staff. The operating budget for 1998 was 1.7 billion old Rbls, which amounted to about 54 new Rbls per child per day. The Oblast hopes to place many children now in the orphanage in foster homes (a system of psychological testing to screen potential foster parents is being developed) and to give a per diem allowance of 16 new Rbls to the foster families to subsidize the costs of adoption and care. Further rationalization is planned -- this orphanage will be merged with a school for handicapped children to form a single, larger institution. Once children have been placed with foster parents, they will be "mainstreamed" and admitted to regular schools. Parents of other children in the schools have objected, but the authorities are confident that this resistance will be overcome.

\section{Box D2: Samara Palace of Youth and Children}

The Samara Palace of Youth and Children is located near the old city center of Samara in an estate house, built in 1904, of a former Russian aristocrat. The Palace is a combination boys and girls club and centralized institution for extra-curricular activities. It is one of nine such centers in the region. This one serves the city and also coordinates broader extra-curricular activities for the entire region, including a wide range of summer camps. The center includes a library, which contains a databank of teaching and educational materials that can be accessed by teachers, parents and others. Some 4,000 students, 4 to 18 years old, take part in the 311 different programs that the Palace offers. The programs include art, computers, photography, economics and business courses, as well as other technical, applied and creative classes. There are also special courses for gifted students. The two-hour classes are offered from 9 to 11 in the morning and from 3 to 9 in the evening. Some of the students use the skills and talents developed at the Palace to compete in various regional and national Olympiads and other competitions. The Palace's 37.2 million ruble budget comes from the regional and city budgets, from parents' and sponsors' contributions, and from the Committee on Women and Children. The programs are free-of-charge to all children.

Samara also supports a range of institutions that offer specialized extra-curricular activities. One such institution, visited by the study team, is the Samara Palace of Youth and Children (see Box D2), one of nine such institutions in the Samara Region.

\section{Private Schools}

Private education serves two groups in Samara -- the very well-off and those with behavioral problems or learning disabilities. About $2 \%$ of secondary school students throughout the Region are enrolled in private schools, and 5-7\% of post-secondary school students. Private school fees are not regulated in Samara, but the system of accreditation acts as a mechanism of quality control. Private institutions are usually subsidized in part, once they become accredited, by receiving rent-free facilities from the regional or municipal authorities. Also, private schools are given a tax break if they can show that they have re-invested their profits back into the institution. Anecdotal evidence suggests that competition among private schools keeps the fees down. The typical monthly fee ranges from 700 to 1000 new Rbls. One private training institution visited in Tolyatti was charging $\$ 15$ a month for 6 hours of extra-curricular instruction per week; teachers received additional pay (averaging between 900 and 2,000 new Rbls per month, i.e., $\$ 150-\$ 300$ ) for their extra work. An issue with which Samara is grappling is whether or not to finance the retraining of teachers in private schools. 


\section{Elite Schools and the Equity Issue}

In common with the rest of the RF, Samara has its share of elite schools (gymnasia and lyceums) which have close links to higher education institutions. Many classes in these schools are taught by academic staff from nearby universities, and the final examinations in the schools are often the same as the university entrance examinations. These schools are quite selective in their intake of students. For the most part, they attract "intelligentsia" children, not the "superrich," who tend to be sent abroad for their studies. The standards of such schools are high pupils do very well in the School Olympiads, and it is not uncommon to see serious research work undertaken by pupils under supervision of the university-based instructors. Pupils of the elite schools (for example the Medical Technical Lyceum in Samara) progress to courses of similar studies at the third level. Nearly $100 \%$ of students in the Medical Technical Lyceum in Samara gain entrance to the medical university, the aerospace university, or Samara State University (for law, psychology, sociology or journalism). In contrast, only $30 \%-50 \%$ of children from the regular secondary schools gain university entrance. Tuition fees in the high-quality gymnasia and lyceums in Samara are modest as compared with those in many parts of the RF. Fees in the Medical Technical Lyceum are "about $\$ 10$ per month, although some pay nothing, and others can afford to pay more." Teacher-student ratios are lower in the gymnasia and lyceums, because the parents demand smaller classes.

In theory, less well-off children in Samara also have access to these elite schools and will not be charged. However, this is probably true only for especially gifted children. Average children from poorer families attend compulsory schools with few optional subjects, guest lecturers and special equipment. They are unlikely to have access to a school counselor. The potential effects of this system of elite schools on late developers and children from poor families is discussed in Chapter 1. 


\section{ANNEX E: NOVGOROD VILIKI REGION}

\section{Characteristics of the Region}

Novgorod Region ${ }^{44}$ is located in northwest Russia, 592 kilometers north of Moscow and 180 kilometers south of St. Petersburg. While it would seem to be an advantage to be located so near Russia's to two major metropolitan centers, at present, location seems to be working toNovgorod's disadvantage, as the bulk of attention, foreign investment and tourism is attracted to the larger urban agglomerations, bypassing Novgorod. The oblast's center, the city of Novgorod, lacks an international airport, and the transport links between Moscow and St. Petersburg are not well-developed. This is a situation typical of many Russian regions with little well-developed industry and no large deposits of fuel or energy products.

Novgorod's population of 739 thousand (as of the beginning of 1997) is spread out among 10 cities and 21 rural raions. A third of the Region's population lives in Novgorod City, the oblast's center, which has a population of 240 thousand. The city and surrounding Novgorod rayon contain about 40 percent of the total population.

Like many regions in western Russia, Novgorod's population has been declining quite precipitously over the past few years, after peaking in 1990 at 755 thousand. Novgorod's population has declined by 1.8 percent since then, attributable mainly to the excess of deaths over births. There has been a moderate amount of in-migration to offset the natural decrease. Currently the rate of natural decrease (difference between births and deaths) is double the natural average, attributable to the older age structure of the region as compared with the rest of the country. As such, the population will continue to decline into the foreseeable future, and this will have an impact on the labor force as well as on the educational system and the delivery of other social services. The population is projected to decline by 6 percent by the year 2010, to 694 thousand. However, the young population of school age (those 16 years or less) are expected to decline by 20 percent, from 150 thousand at present, to 119 thousand, thus reducing significantly the demand for teachers and other educational services.

The Region's per capita product, which at 5,924 New Rbls (approximately $\$ 1,301$ ) was only 62 percent of the national average in 1995. Other indicators of wealth, such as average wage and income, are also lower than the national average. One bright spot in Novgorod's economy is the fact that the poverty rate is lower than the national average - in 1996, only 17.6 percent of Novogorod's population had incomes less than the subsistence minimum versus 22 percent nationally.

Not surprisingly, like most regions in Russia, Novgorod is a net recipient in terms of the federal budget, receiving 4 percent of its total revenues in the form of federal transfers in 1997. There are no raions within Novgorod Oblast that are net donors.

44

The Region discussed in this Annex is Novgorod Viliki or Novgorod the Great which should not be confused with Nizny Novgorod. 
Table E1 Novgorod, Selected Education Indicators, 1990-1997

\begin{tabular}{|c|c|c|c|c|c|c|c|c|}
\hline & 1990 & 1991 & 1992 & 1993 & 1994 & 1995 & 1996 & 1997 \\
\hline Number of school-age children $(0-16)$ & 167.8 &.. & .. & .. &. & 158.7 &.. & 150 \\
\hline School-age children as share of total & 22.3 &.. &.. & .. &.. & .. & .. & 20.3 \\
\hline \multicolumn{9}{|l|}{ Pre-schools } \\
\hline Number of schools & .. & .. &.. &.. & .. & .. & .. & .. \\
\hline Number of places (thousands) &. & .. &.. &.. &.. & -. &.. & .. \\
\hline Number of students (thousands) & .. & .. &.. & .. &. & .. & .. & .. \\
\hline Number of teachers & .. &.. & .. &.. &. & .. &. & $\cdot$. \\
\hline Student-teacher ratio & .. & .. &.. &.. &.. &.. & .. & .. \\
\hline Enrollment ratio & 71.7 & 70.1 & 64.0 & 65.8 & 62.2 & 62.1 & .. & .. \\
\hline \multicolumn{9}{|l|}{ Compulsory schools } \\
\hline Number of schools & 405 & 401 & 393 & 401 & 391 & 391 & .. & .. \\
\hline Number of students (thousands) & 94 & 95 & 97 & 98 & 101 & 103 & .. & .. \\
\hline Percent on second shift & 16.7 & 18.3 & 17.6 & 18.4 & 19.9 & 19.1 &.. & . \\
\hline Number employed in education (thousands) & .. & .. & .. &.. & .. & .. & .. & \\
\hline Number of teachers (thousands) &. &.$\cdot$ &. &.. &. & .. &. & .. \\
\hline Percent teachers in education & .. & .. &.. &.. & .. & .. & .. & .. \\
\hline Student-teacher ratio & .. &.. &. & .. & .. & .. & .. & .. \\
\hline Enrollment ratio &.. &.. & .. &. & .. & .. & .. & .. \\
\hline \multicolumn{9}{|l|}{ Specialized secondary schools } \\
\hline Number of schools &.. & .. & .. & .. & .. &.. &.. & .. \\
\hline Nuınber of students (thousands) & 11.1 & 10.9 & 9.9 & 9.8 & 9 & 9.3 &.. & \\
\hline Number of teachers & .. &.. & $\cdot \cdot$ &.. & .. & .. &.. & .. \\
\hline Student-teacher ratio & .. &.. &.. & .. & .. &. & .. & .. \\
\hline Enrollment ratio & -. &.. &.$\cdot$ &.$\cdot$ & .. & .. &.. & .. \\
\hline \multicolumn{9}{|l|}{ Higher educational instituions } \\
\hline Number of schools & *. & .. & .. & .. &.. & .. &.. & .. \\
\hline Number of students (thousands) & 8.9 & 9.1 & 9.2 & 9.0 & 9.4 & 10.3 & .. & .. \\
\hline \multicolumn{9}{|l|}{ liducation finance indicators } \\
\hline Total public expenditures on education (million rubles) & .. &.. & .. & .. &.. & .. &.. & .. \\
\hline Salaries (percent) & .. &. & .. &.. &. &. &.. & .. \\
\hline Medicine (percent) & .. &.. &.. &.. & .. &.. & .. & .. \\
\hline Meals (percent) & .. &.. &.$\cdot$ &. &.$\cdot$ &.. & .. & .. \\
\hline Capital investment (percent) & .. &.. & .. &.. &.. & .. & .. & .. \\
\hline Civil works (percent) &.$\cdot$ &.. &.$\cdot$ & .. &. & .. & $\cdot$. & . \\
\hline Other (percent) & .. &.. &. &.. &.$\cdot$ &.. & .. & .. \\
\hline Education expenditures as a share of consolidated budget (percent) & .. &.. & .. &.. &. & .. & .. & .. \\
\hline Average wage in education as percent of average oblast wage & .. &.. &.. &.. &.. & .. &.$\cdot$ & .. \\
\hline
\end{tabular}

Sources and notes:

Goskomstat Rossi, Regiony Rossii, 1997; Goskonstat Rossii, Rossiyskiy statisticheskiy yezhegodnik, 1996.

The number of school-age children given for 1990 are actually for 1989 .

.. Not available 


\section{Limited Scope for Mobilizing Additional Resources for Education}

As discussed above, Novgorod is a relatively poor region, only 57 th among the 79 subjects of the Russian Federation (excluding autonomous okrugs) in terms of per capita gross regional product, while Samara is ranked $8^{\text {th }}$ in the country. It is not surprising that the Education Administrations of Novgorod and Samara have differing views as to the importance of different issues affecting education in Russia. The number-one issue in the minds of Education Administration officials in Samara is how to use existing budgetary resources more efficiently so as to raise the quality of education. The attention of Novgorod's Education Administration, on the other hand, is focused on the low level of resource flows and on ways to augment the consolidated education budget of the Region so as to satisfy, at the very least, the minimum educational standards required under the Russian Constitution and under various federal laws. ${ }^{45}$

Education financing in the Region cannot keep pace with the demands on the system. The revenues currently available for education cover only 30-40 percent of Novgorod's "planned" budget for education. The "planned" budget, which includes all federally "mandated" expenditures (i.e., staff salaries and benefits, and student meals) plus, according to education officials in the region, "just a little bit more," is largely a function of staff currently employed in the education system. One response of the Region is to emphasize the importance of institutional autonomy and of revenues raised and utilized at the institutional level -- from "additional education" (courses that are not part of the basic curriculum and for which fees can, therefore, be charged) and from other goods and services offered for sale to the community. However, while many school directors make heroic efforts in this regard, they can hardly be expected to close the large resource gap.

The Director of the Oblast Education Administration negotiates with his peers, the Regional Duma and the Governor in an effort to obtain more budget for education, while at the same time encouraging all raion heads of administration to recognize the importance of education for the development of their districts. However, the fact is that, faced with difficult choices between allocating resources to keep the hospitals or the schools running, education often comes off second-best. Even within the education sector, there is also often a choice between paying teachers or heating the schools in winter, and as a result, teachers are often paid late. It is not surprising, therefore, that oblasts such as Novgorod are looking to Moscow in the hope that the Federal Government will assume a larger share of the responsibility for delivering educational services throughout Russia.

Novgorod's Director of Education is also the current President of the Association of Education Administrators (a group of Education Heads of Administration from 39 regions of the country). Early in 1998, this Association signed a petition to the MGPE arguing that, whereas about $30 \%$ of the education curriculum and a large number of norms and standards have been mandated by the Federal Government, nevertheless, the Federal Government contributes relatively little in the way of financing for education, leaving the regions with a long list of unsatisfied mandates. The proposal of the Association is that federal subventions to the regions be increased so as to cover fully the costs of delivering the federal component of the education curriculum. The logic of this request is understandable, but the political feasibility of its being met, during a time of continuing federal government budget cuts, would seem to be quite low. The Regional Administration is further proposing that, if and when the Federal Government

45 Both Samara and Novgorod are also concerned with the structure and efficiency of vocational education and training -- both internal efficiency (how to reduce unit costs) and external efficiency (how to strengthen labor market linkages and enhance employment outcomes). 
agrees to increased funding earmarked for education, these monies be channeled directly from Federal Government to institutional bank accounts via a new "treasury system." The idea is to avoid problem of diversion of education funds at oblast and raion levels.

Probably the Federal Government, and in particular the Ministry of Education, would be more sympathetic to a reformed system of subventions if these could be somehow targeted to regions based on financial "need." Even if the Federal Government were to increase its direct expenditures for professional education, as well as the sum total of its subventions to regional governments to support regional programs, it is unlikely that there would ever be "enough to go around." What, therefore, makes sense is a new federal funding formula for assistance to regional governments that would take into account: (i) "ability to pay" (income differences); (ii) cost factors (differentiating, for example, between regions that are within, or far distant, from Moscow and Western Russia, or between regions that are more and less densely populated); and (iii) local "effort" (as measured by the tax revenues raised by each region relative to its income level). ${ }^{46}$

\section{Inefficient Uses of Existing Resources}

The paradox of high student-teacher ratios and the apparent "shortage" of teachers has already been discussed in Chapter 1 of this report. Novgorod Region offers a clear illustration of how teaching loads and class sizes in urban and rural schools are contributing to both pedagogic and fiscal inefficiencies. There are 10,000 teachers of primary, secondary and vocational education in the Region, 97\% of whom are female. As in Samara, 10\% of teachers are pensioners, retained because of the lack of teachers in certain disciplines. Throughout Russia, the standard teaching load in secondary education is 18 class periods per week. However, in some urban schools teachers may teach many more classes (as many as 32 or 36 hours per week) and are paid at the same rate for each additional hour as for first 18 hours. So, in effect there are no budgetary savings from having teachers work over-time hours. The situation in some rural raions in the region, however, is quite different. There, even with many teachers responsible for two or more compulsory-level subjects, some teachers have less than a full-time load. If, however, these teachers are on regular teaching contracts, ${ }^{47}$ they are, nevertheless, paid for the 18-hour minimum.

In addition to different teaching loads, there are significant interraion variations in staffstudent ratios. The average class size in the region is 25 , but in some urban areas, schools are overcrowded and classes are much larger. In such areas, there is often the need to operate two or even three shifts, and teachers may work more than 10 hours in a day. In rural schools, the situation is usually quite different.

\section{The Special Problems of Rural Schools}

Novgorod demonstrates the special problems encountered in many rural schools throughout Russia. In Novgorod, approximately $70 \%$ of schools and $50 \%$ of teachers are located in rural areas, whereas only $25 \%$ of students live in rural areas. As a result, teachers and facilities are relatively underutilized in rural areas of the Region. 48 Average expenditure per student across

\footnotetext{
46 The problem with the existing system of block grants is that it does not allow targeting.

47 As opposed to part-time contracts, which also exist, e.g., for retired teachers, or for university lecturers who "moonlight" teaching in schools.

48 One anomaly related to this issue is the definition of rural areas. Any place outside a city or a town is defined as a rural area. Even the suburbs of Novgorod city, only 10 to 12 minutes away from the center, are considered
} 
raions varies from 2,100 to 3,000 new Rbls (about $\$ 350$ to $\$ 570$ ). The share of education in raion budgets varies from $20 \%$ to $34 \%$.

Whether teachers are teaching full loads or not, student-teacher ratios in most rural schools are much lower than in cities. Rural classes rarely approach 25 students (the maximum allowed according to federal regulations), and in some locations they dip as low as 2 students in a class. In 1995, the average teacher-student ration was 1:8. Teachers in rural areas receive $25 \%$ higher salaries than those teaching in urban areas. In addition, in theory, they also receive free housing; however, since they have to pay for housing first themselves and then claim reimbursement from the region, given current budgetary constraints many rural teachers do not, in fact, receive their housing allowances, not at least in timely fashion. There have also been delays of varying duration in the payment of teachers' salaries in Novgorod

Although multi-grade teaching is used in some parts of Novgorod Region, it is seen as undesirable and, at best, a stop-gap solution. It is seen as a burden by most teachers, who do not have the training for multi-grade teaching, and there is suspicion that this approach compromises student learning. There are also concerns among Regional Administration staff that teachers in rural schools who are teaching more than one subject are not acceptably proficient in the second subject. Most teachers with university education and better teaching qualifications do not want to live in rural areas which, in turn, raises the issue of retraining for rural schoolteachers (discussed below).

Novgorod Region does not show willingness to adopt Samara's solution of creating school clusters for students beyond primary, merging small schools in raion centers and introducing busing. There are other partial solutions possible, such as alternate-year school intake (instead of having a Form 1 in every year, grouping younger and older children only in alternate years).

\section{Issues Relating to Teachers}

In Novgorod Region, there is little growth in the number of teaching positions, as student numbers are either stagnant or in decline in all school districts. About $6 \%-8 \%$ of the total teaching force (450-650 teachers) retires or leaves the profession each year in the region. They are replaced by new graduates from teacher training institutions where possible, although there are not now enough graduates to fill the annual gap. In recent years, about $10 \%$ of new teachers have also been recruited from Russian teachers who immigrate to Novgorod from Central Asia and other parts of the FSU.

For teachers to advance up the salary scale, there is a complicated system of attestation divided into three main categories, with the top category further divided into three sub-categories. Those teachers in the middle category earn about $25 \%$ more, and those in the top category $50 \%$ more than those in lowest category. There are about 40 salary steps in the scale, and new teachers earn about $61 \%$ of what retiring teachers earn, all else equal. About $80 \%$ of teachers are university graduates. The remainder come from PTUs and teacher training colleges. Nonuniversity graduates earn about $88 \%$ the salary of graduate teachers. As in other regions, many retired teachers continue working and receive a full pension and earn a full teacher's salary at the same time.

rural areas, and teachers there are able to claim the $25 \%$ increase in salaries and other benefits intended for teachers in remote rural areas. 
Unlike Samara, Novgorod has experienced problems in paying teachers' salaries. In March 1998, when the study team visited, salaries were only about one month in arrears, but longer delays previously were reported. The view of the teaching profession expressed in Novgorod is that, as teachers are mostly women and the job "suits them," they put up with these conditions. However, there is a worry that, if the situation persists, teachers will leave the profession. The poor incentives will discourage new entrants and undermine, eventually, the dedication and performance of those already in the profession.

\section{Teacher Training and Re-training}

Teacher training and re-training systems in Novgorod follow federal norms (see description in Annex D, paras. 21 and 22). In Novgorod, the Teacher Training College is linked with the Pedagogical University, an arrangement that allows a student with good grades to proceed automatically for three further years of study and earn their degree. New courses have been added to the teacher training curriculum, especially in the Pedagogical Universities. New psychology and sociology courses aim to prepare students as counselors or social workers. These courses are now quite popular, and there is a growing demand for such services at schools, especially in urban areas. Only $62 \%$ of primary school teachers and $89 \%$ of those teaching grades 5 to 11 have completed university education. Rural schools have disproportionately large numbers of non-degree teachers.

About $70 \%$ of students in teacher training colleges in Novogorod are from rural areas. The comparable figure in Samara is 35\%.49 As in Samara and many other regions of RF, Novgorod has special incentives to attract student teachers from rural areas. These teachers receive preferential entrance into teacher training, ${ }^{50}$ and they are paid additional stipends during the training period. In return, graduates of these programs are obliged to enter into a contract with rural school directors to spend a minimum of three years in rural schools.

\section{Textbook Supply}

As the funding for textbooks is not a protected budget item, purchases of new textbooks and educational materials have suffered in recent years in both urban and rural areas. ${ }^{51}$ On balance, however, most pupils are provided with textbooks, although one third of textbooks remain in use for more than 4 years. Teachers in both urban and rural schools receive their choice of textbook from the Federal List by filling up an order form. They depend on teacher training courses to get information about what additional textbooks are available.

On closer examination, there are marked discrepancies between textbook supply in the cities, including nearby raions, and the supply in more remote rural raions. The Novgorod City schools that the mission visited (\#22 and \#33) are fully supplied with core textbooks, both in terms of titles and numbers of copies. They may have a problem with accessing textbooks for innovative programs and additional courses, in which case these books are generally purchased

49 One explanation for the high proportion of student teachers from rural areas in teacher colleges could be that many rural schools offer only 9 grades of tuition, and therefore, pupils in these schools would not normally be able to compete for university. The education gained in a teacher training college and the additional prospect of going on to pedagogical university are undoubted incentives for students from rural areas to enter teacher training.

50 Students finishing teacher training can continue at a pedagogical university without being required to receive the grade normally needed to enter the university.

51 Of the three raions visited, only one had funds to spend on textbooks and teaching materials. 
by parents. According to the school principals, up to $60 \%$ of parents can afford such purchases. For poorer students, the city schools buy the special textbooks using their own funds and contributions from parents.

Rural schools get all the titles they order, but only about a third of the number of copies needed. To fill the gap, raion educational authorities have implemented a system whereby parents can order textbooks and receive them within a week. This arrangement is made through a "Shop-Depot," established in each school. According to the teachers interviewed, $40 \%-50 \%$ of parents can afford to buy textbooks. Other students are provided with used textbooks free of charge. However, these used books tend to be at least four years old. So the children of poorer families in rural schools are not getting the most up-to-date learning materials, unlike children from similar income groups in the cities. A book hiring system, or an arrangement whereby parents could buy second-hand textbooks from the prior school year, would greatly ease this situation in rural areas.

\section{Other Education Initiatives in Novgorod}

In spite of serious fiscal constraints, the education system in the Novogorod region benefits from a very active and high profile administration team who are prepared to introduce innovation in both the financing, governance and content of education. Box E1 is on example of one initiative.

\section{Reform of Accounting Pro cedures for Municipal Education Facilities}

\section{Box E1: Borovichi Raion Pilot}

The Municipal Education Department Central Accounting Office (CAO) which formerly provided centralized services to about 70 education facilities was restructured to maintain separate accounting for kindergartens and nursery schools, comprehensive schools and other education facilities. A bank account was opened for each group to ensure that funds would be used as intended.

The key objectives of the pilot were to ensure:

- Quality, flexible service to educational facilities;

- Right of the school director to administer own funds on the basis of the new accounting arrangements system and changed CAO Structure;

- Training on the school director and accountant to working in conditions of financial independence.

Activities: (1995-1996)

- Accountant assigned to each participating education facility;

- All opened own bank settlement and budget accounts;

- Each director was authorized to sign financial documents; income earned (both budget and extra-budget) lodged in own accounts; and no longer fear that these funds could be "assigned" to some other facilities.

Lessons learned:

- Availability of an individual account fostered activities in the field of earning additional funds;

- School Director had new freedom of maneuver with funds and actually became a "manager" knowledge in finance;

- However, School Directors knew nothing about financial issues and needed appropriate training.

Source: Novgorod Regional Administration, Report on the Decentralization of the Central Accounting Office Functions to Selected Municipalities and Schools (1997)

\section{Initiatives to Restructure First- and Second-Level Vocational Education}

As with Samara, Novgorod Region has taken over the management of first-level vocational education from the Federal Government. Consequently, there has been an increase in the regional budget for vocational education which was 3.5 million new Rbls in 1997, as compared with 2.1 
million in 1995 although it is unclear whether there has been a corresponding increase in the contribution from the Federal Budget.

A program has been designed to reorient and modernize the vocational education system in Novgorod. In this program, vertical administrative responsibilities of different line ministries have been eliminated, and the MGPE and regional education administration have taken over responsibility for most aspects of vocational education in the region. The outcome is expected to be a more efficient and better coordinated system, larger enrollments per institution (with associated economies of scale -- less duplication, lower administrative costs, larger classes and better utilization of facilities) and greater flexibility and responsiveness to the needs of the labor market. However, the fact that Novgorod is quite depressed economically makes the program of vocational education restructuring difficult. It is not clear what the labor market will require in the longer term.

The Regional Administration has created a Vocational Education Board to address the strategic governance and policy issues that are expected to arise from a program of horizontal integration. ${ }^{52}$ The Board has been set up to identify and exploit the advantages of the system's administrative transfer to the region, to suggest ways of implementing a coordinated policy for vocational education and to address the strategic governance and policy issues that are anticipated from their reform program. Table E2 presents some agreements and elements of progress to date.

The Regional Vocational Education program proposes that a new set of regional vocational education standards be created with an emphasis on training for new specialties and with appropriate quality measurement and availability of educational materials. PTUs and teknikums are establishing many new courses in more general subjects (e.g., management, economics, law, commerce). In order to make the system more client oriented and to adjust the new courses to students' needs and labor market demands, three questionnaires have been prepared: one for students, one for enterprises and one to test vocational institutions for labor market relevance. The ultimate target of the program is the creation of the single system of vocational education in the region. Some vertical integration is proposed through the incorporation of teknikums and pedagogical institutes into university structure. Some attempts have been made to close dead-end specializations, but progress on this appears slow. A major problem is the dilemma of what to do with existing teaching staff who cannot easily be retrained to teach the new modern courses.

52 The membership of the 15-person Board (nine from the Administration, one from higher education, one from the Teachers' Trade Union, two from Vocational Institutions, and two employer representatives) may be heavily weighted in favor of the Administration, but the objectives of the Board are sound. 
Table E2 Agreement on Authority Sharing in the Vocational Training Sector

\begin{tabular}{|c|c|}
\hline Oblast education committee & Local governments \\
\hline $\begin{array}{l}\text { - Implements the federal and } \\
\text { regional policy } \\
\text { - Drafts normative acts } \\
\text { - Supervises observation of state } \\
\text { standards } \\
\text { Opens, reorganizes and } \\
\text { liquidates vocational training } \\
\text { schools (VTS) upon agreement } \\
\text { with municipal and rayon } \\
\text { administrations } \\
\text { - Conducts certification and state } \\
\text { accrediting of VTS } \\
\text { Establishes regional standards } \\
\text { - Establishes requirements to } \\
\text { educational process equipment in } \\
\text { addition to the federal } \\
\text { requirements } \\
\text { Ensures scientific } \\
\text { methodological support of } \\
\text { vocational training } \\
\text { Coordinates personnel training } \\
\text { by sector and rayon (including } \\
\text { orphans and special needs) } \\
\text { Makes projections of vocational } \\
\text { training development, reference } \\
\text { admission and graduation } \\
\text { numbers } \\
\text { Coordinates integrational and } \\
\text { cooperative activities between } \\
\text { education facilities } \\
\text { Issues licenses for primary } \\
\text { vocational schools } \\
\text { Finances primary vocational } \\
\text { schools Appoints education facility heads } \\
\text { (upon agreement with the local } \\
\text { governments) } \\
\text { Reviews and approves curricula } \\
\text { of vocational schools and } \\
\text { lyceums }\end{array}$ & $\begin{array}{l}\text { - Organize vocational training in } \\
\text { compulsory schools together with } \\
\text { primary vocational education schools } \\
\text { (training course "Technology") } \\
\text { - Develop and implement targeted } \\
\text { vocational training programs } \\
\text { together with VTS, city/rayon } \\
\text { entrepreneurs, employment services } \\
\text { and other interested organizations } \\
\text { - Coordinate cooperation between } \\
\text { VTS and employers } \\
\text { Make proposals to the Oblast } \\
\text { education committee on creation, } \\
\text { reorganization and liquidation of } \\
\text { VTS on their territory } \\
\text { Prepare proposals on formation of a } \\
\text { VTS network, identify the } \\
\text { admittance amount, the number of } \\
\text { students, the list of trades and } \\
\text { specilizations required due to the } \\
\text { city/rayon economy development } \\
\text { trends and employers needs } \\
\text { Implement the policy of early } \\
\text { vocational training of schoolchildren } \\
\text { under the pre-higher education } \\
\text { programs } \\
\text { Evaluate and analyze the vocational } \\
\text { training efficiency jointly with the } \\
\text { Oblast education committee }\end{array}$ \\
\hline
\end{tabular}




\begin{tabular}{|c|c|c|c|c|c|}
\hline & \multicolumn{3}{|c|}{$\begin{array}{r}\text { As a percent } \\
\text { of or compared }\end{array}$} & \multicolumn{2}{|c|}{$\begin{array}{r}\text { As a percent } \\
\text { of or compared }\end{array}$} \\
\hline & Russia & Novgorod & to Russia & Samara & to Russia \\
\hline \multicolumn{6}{|l|}{ Geography } \\
\hline Area (ths. sq. kms.) & 17,075 & 55 & 0.3 & 54 & 0.3 \\
\hline Number of cities a) & 1,092 & 10 & 0.9 & $\mathrm{Ii}$ & 1.0 \\
\hline Number of rural rayons & 1,869 & 21 & 1.1 & 27 & 1.4 \\
\hline Distance from Moscow (kms.) & & 592 & & 1,098 & \\
\hline \multicolumn{6}{|l|}{ Population } \\
\hline Total 1997 (ths.) & 147,502 & 739 & 0.5 & 3,310 & 2.2 \\
\hline Percent urban & 73 & 71 & 97.1 & 81 & 110.1 \\
\hline Population in largest city, 1997 (ths.) & 8,639 & 240 & & 1,204 & \\
\hline Percent of region in largest city & 6 & 32 & & 36 & \\
\hline Percent Russian, 1989 & 82 & 95 & & 83 & \\
\hline Total, 1989 (ths.) & 147,401 & 753 & 05 & 3,266 & 22 \\
\hline Percent change, 1989-1997 & 0.1 & -1.8 & & 1.4 & \\
\hline Natural increase & -1.6 & -5.6 & & -2.1 & \\
\hline Net migration & 1.7 & 3.8 & & 3.5 & \\
\hline Absolute change, 1989-1997 (ths.) & 102 & -14 & & 44 & \\
\hline Natural increase & $-2,409$ & -42 & & -69 & \\
\hline Net migration & 2,511 & 28 & & 114 & \\
\hline Projected population, 2010 (ths.) & 143,704 & 714 & & 3,319 & \\
\hline Average age, 1997 (years) & & 38.1 & & 36.6 & \\
\hline Share of pop. below working ages, 1997 & 22.0 & 20.3 & & 20.6 & \\
\hline Share of pop. in working ages, 1997 & 57.3 & 55.6 & & 58.8 & \\
\hline Share of pop. above working ages, 1997 & 20.7 & 24.1 & & 20.6 & \\
\hline \multicolumn{6}{|l|}{ Economic } \\
\hline \multicolumn{6}{|l|}{ Gross regional product, 1995 (ths. rubles) } \\
\hline Regional product per capita, 1995 (ths. rubles) & 9,562 & 5,924 & 62.0 & 13,612 & 142.3 \\
\hline Employment by branch, 1995 (percent) & 100.0 & 100.0 & & 100.0 & \\
\hline Industry and construction & 35.2 & 38.4 & & 43.3 & \\
\hline Agriculture & 15.1 & 13.9 & & 9.0 & \\
\hline Services & 49.7 & 47.7 & & 47.7 & \\
\hline \multicolumn{6}{|l|}{ Social Indicators } \\
\hline Average monthly income, 1996 (ths. rubles) & 764.2 & 681.7 & 89.2 & 691.0 & 90.4 \\
\hline Monthly subsistence minimum, 1996 (ths. ruble & 369.4 & 325.3 & 88.1 & 351.2 & 95.1 \\
\hline Ratio of average wage to subsistence minimum & 206.9 & 209.6 & & 196.8 & \\
\hline Average monthly expenditures, 1996 (ths ruble & 531.8 & 460.6 & 86.6 & 630.7 & 118.6 \\
\hline Average monthly wage, 1996 (ths. rubles) & 790.2 & 621.9 & 78.7 & 911.1 & 1153 \\
\hline Monthly minimum wage, 1996 (ths. rubles) & 415.6 & 367.2 & 88.4 & 397.5 & 95.6 \\
\hline Average monthly pension, 1996 (ths. rubles) & 320.1 & 293.0 & 91.5 & 298.4 & 93.2 \\
\hline \multicolumn{6}{|l|}{ Percent of pop. below subsistence minimum } \\
\hline 1994 & 22.4 & 17.5 & 78.1 & 18.1 & 80.8 \\
\hline 1995 & 24.7 & 22.8 & 92.3 & 21.2 & 85.8 \\
\hline 1996 & 22.0 & 17.6 & 80.0 & 20.1 & 91.4 \\
\hline Car ownership, 1996 (cars per 100 households) & 17.9 & 8.4 & 46.9 & 22.0 & 122.9 \\
\hline
\end{tabular}

Sources and notes:

Goskomstat Rossii, Chislennost' naseleniya Rossiyskoy Federatsii po gorodam, poselkam gorodskogo tipa i rayonam na 1 yanvarya 1997 g.; Sotsial'noye polozhenive i uroven' zhizni naseleniya Rossii: statisticheskiy sbornik, 1997; Demograficheskiy yezhegodnik Rossii: statisticheskiy sbornik (selected years).

a) The city of Samara is further divided into 12 urban rayons. 


\section{ANNEX G: STATISTICAL ANNEX}

\section{Annex G1: Selected General Indicators by Region in Russia}

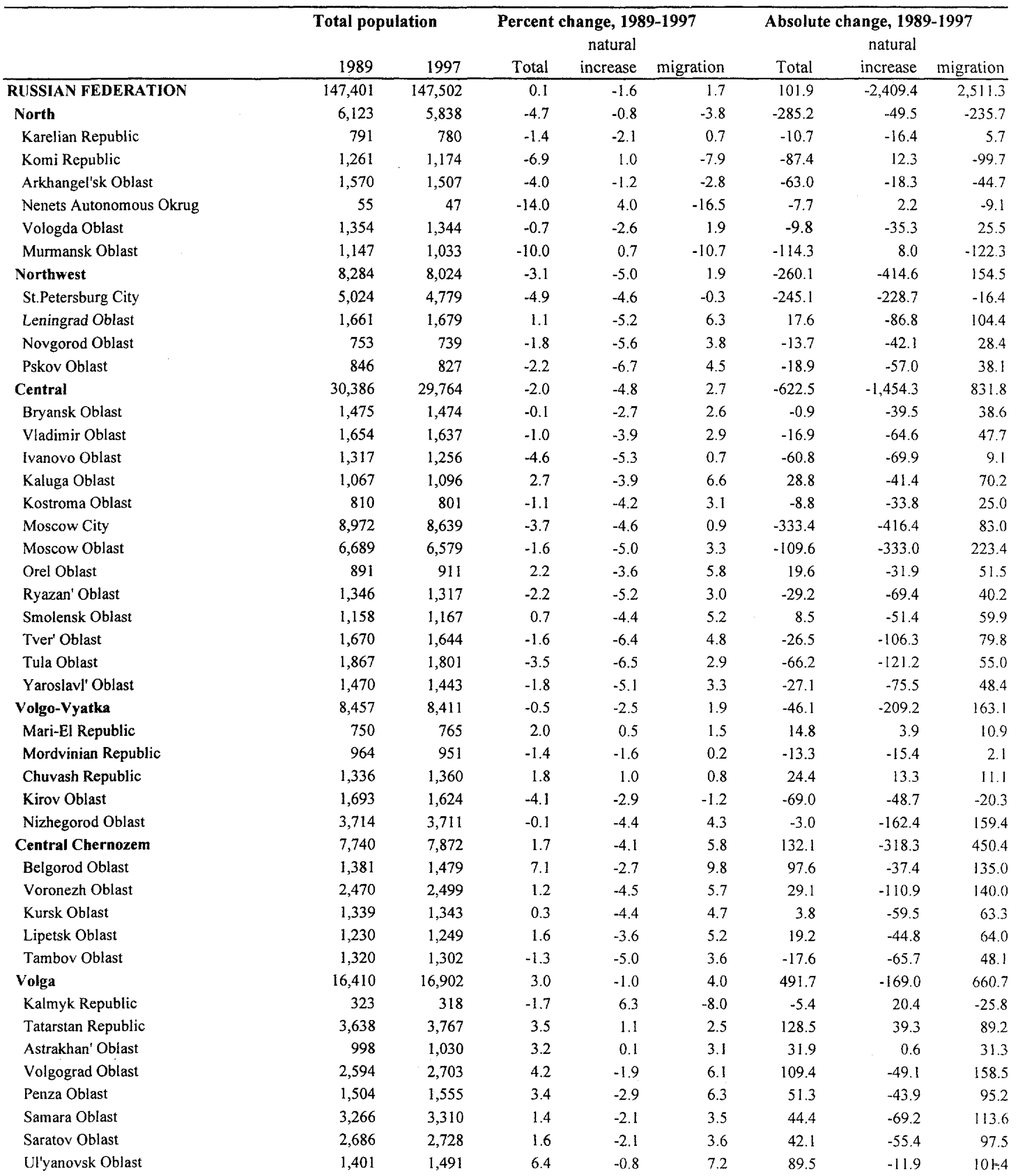




\section{Annex G1: Selected General Indicators by Region in Russia}

\begin{tabular}{|c|c|c|c|c|c|c|c|c|}
\hline & \multicolumn{2}{|c|}{ Total population } & \multicolumn{3}{|c|}{$\begin{array}{c}\text { Percent change, 1989-1997 } \\
\text { natura! }\end{array}$} & \multicolumn{3}{|c|}{$\begin{array}{c}\text { Absolute change, } 1989-1997 \\
\text { natural }\end{array}$} \\
\hline & 1989 & 1997 & Total & increase & migration & Total & increase & migration \\
\hline North Caucasus & 16,751 & 17,702 & 5.7 & $\mathrm{I} .1$ & 4.6 & 950.5 & 187.1 & 763.5 \\
\hline Adygey Republic & 433 & 450 & 3.9 & -1.3 & 5.2 & 17.0 & -5.6 & 22.6 \\
\hline Dagestan Republic & 1,803 & 2,074 & 15.0 & 14.0 & 1.0 & 270.6 & 252.6 & 180 \\
\hline Ingushetia Republic & .. & 309 & 46.8 &.. & .. & 98.4 & .. & \\
\hline North Ossetian Republic & 634 & 665 & 4.9 & 2.8 & 2.1 & 31.2 & 18.1 & 13.1 \\
\hline Checheniya Republic & 1,275 & 813 & -25.9 & .. & .. & -284.8 & & .. \\
\hline Krasnodar Kray & 4,680 & 5,070 & 8.3 & -2.5 & 10.8 & 390.2 & -116.3 & 506.5 \\
\hline Stavropol' Kray & 2,439 & 2,674 & 9.6 & 0.0 & 9.7 & 234.8 & -1.1 & 235.9 \\
\hline Rostov Oblast & 4,309 & 4,420 & 2.6 & -2.6 & 5.2 & 111.0 & -112.8 & 223.8 \\
\hline Kurgan Oblast & 1,105 & 1,107 & 0.2 & -1.2 & 1.4 & 1.8 & -13.8 & 15.6 \\
\hline Orenburg Oblast & 2,174 & 2,227 & 2.4 & 0.6 & 1.8 & 52.9 & 13.8 & 39.1 \\
\hline Perm' Oblast & 3,100 & 2,998 & -3.3 & -1.7 & -1.6 & -102.5 & -52.1 & -50.4 \\
\hline Komi-Permyak Aut. Okrug & 160 & 156 & -2.8 & 0.1 & -1.9 & -4.4 & 0.2 & -3.1 \\
\hline Sverdlovsk Oblast & 4,717 & 4,670 & -1.0 & -2.7 & 1.7 & -47.2 & -128.4 & 81.2 \\
\hline Chelyabinsk Oblast & 3,624 & 3,678 & 1.5 & -1.4 & 2.9 & 54.1 & -50.4 & 104.5 \\
\hline West Siberia & 15,003 & 15,098 & 0.6 & -0.3 & 0.9 & 95.0 & -39.1 & 134.1 \\
\hline Altay Republic & 192 & 202 & 5.1 & 3.5 & 1.6 & 9.8 & 6.8 & 3.0 \\
\hline Altay Kray & 2,630 & 2,678 & 1.8 & -1.8 & 3.7 & 48.4 & -47.8 & 96.2 \\
\hline Kemerovo Oblast & 3,176 & 3,043 & -4.2 & -2.6 & -1.6 & -133.0 & -83.1 & -49.9 \\
\hline Novosibirsk Oblast & 2,782 & 2,746 & -1.3 & -1.6 & 0.4 & -35.9 & -45.7 & 9.8 \\
\hline Tuva Republic & 309 & 310 & 0.4 & 8.9 & -8.5 & 1.2 & 27.6 & -26.4 \\
\hline Khakass Republic & 569 & 585 & 2.8 & -0.4 & 3.2 & 15.9 & -2.3 & 18.2 \\
\hline Krasnoyarsk Kray & 3,027 & 3,095 & 2.2 & -0.1 & 2.3 & 68.1 & -2.8 & 70.9 \\
\hline Taymyr Autonomous Okrug & 55 & 46 & -17.1 & 3.8 & -19.2 & -9.4 & 2.1 & -10.6 \\
\hline Evenki Autonomous Okrug & 24 & 20 & -17.1 & 5.1 & -20.5 & -4.1 & 1.2 & -4.9 \\
\hline Irkutsk Oblast & 2,831 & 2,786 & -1.6 & 0.7 & -2.3 & -44.8 & 20.2 & -650 \\
\hline Ust'-Orda Buryat Aut. Okrug & 136 & 143 & 5.1 & 6.5 & -1.5 & 7.0 & 8.8 & -2.0 \\
\hline Chita Oblast & 1,378 & 1,287 & -6.6 & 2.5 & -9.1 & -91.3 & 34.3 & -125.6 \\
\hline Aga Buryat Autonomous Okrug & 77 & 78 & 1.8 & 8.4 & -5.8 & 1.4 & 6.5 & -4.5 \\
\hline Far East & 7,941 & 7,422 & -6.5 & 1.6 & -8.1 & -519.5 & 125.7 & -645.2 \\
\hline Sakha Republic (Yakutia) & 1,081 & 1,016 & -6.0 & 7.0 & -13.0 & -65.3 & 75.7 & -141.0 \\
\hline Jewish Autonomous Oblast & 216 & 208 & -3.9 & 2.0 & -5.9 & -8.5 & 4.3 & -12.8 \\
\hline Chukotka Autonomous Okrug & 157 & 85 & -45.6 & 4.0 & -49.6 & -71.6 & 6.3 & -77.9 \\
\hline Primorskiy Kray & 2,258 & 2,236 & -1.0 & 0.1 & -1.1 & -21.8 & 2.0 & -23.8 \\
\hline Khabarovsk Kray & 1,609 & 1,557 & -3.2 & 0.4 & -3.6 & -51.9 & 6.3 & -58.2 \\
\hline Amur Oblast & 1,058 & 1,031 & -2.5 & 1.6 & -4.1 & -26.6 & 16.9 & -43.5 \\
\hline
\end{tabular}


Annex G1: Selected General Indicators by Region in Russia

\begin{tabular}{|c|c|c|c|c|c|c|c|c|}
\hline & \multicolumn{2}{|c|}{ Total population } & \multicolumn{3}{|c|}{$\begin{array}{c}\text { Percent change, 1989-1997 } \\
\text { natural }\end{array}$} & \multicolumn{3}{|c|}{$\begin{array}{c}\text { Absolute change, 1989-1997 } \\
\text { natural }\end{array}$} \\
\hline & 1989 & 1997 & Total & increase & migration & Total & increase & migration \\
\hline Kamchatka Oblast & 466 & 404 & -13.4 & 1.6 & -15.0 & -62.4 & 7.7 & -70.1 \\
\hline Koryak Autonomous Okrug & 39 & 32 & -17.7 & 2.8 & -18.7 & -6.9 & 1.1 & -7.3 \\
\hline Magadan Oblast & 386 & 251 & -34.9 & 1.8 & -36.8 & -134.9 & 7.1 & -142.0 \\
\hline Sakhalin Oblast & 710 & 634 & -10.8 & 0.0 & -10.7 & -76.5 & -0.3 & -76.2 \\
\hline
\end{tabular}

Sources and notes: Population and Population change data are from Goskomstat (via Heleniak)

School age population, 1989: Goskomstat Rossii, Kratkay sotsial'no-demograficheskaya kharakteristika naseleniya RSFSR do

dannym Vsesoyuznoy perepisi naseleniya 1989 godu Chast' $1 \ldots$., 1991, pp. 66-83. Different definition of population is used from 1997

School age population, 1995:

School age population, 1997: Goskomstat Rossii, Demograficheskiy yezhegodnik Rossii: Statisticheskiy sbornik, 1997, pp. 44-46.

.. Not available 
Annex G2: Educational Attainment by Region in Russia , 1994 (persons 15 and older)

\begin{tabular}{|c|c|c|c|c|c|c|c|c|}
\hline $\begin{array}{l}1994 \text {, per thousand } \\
\text { persons } 15 \text { and older }\end{array}$ & $\begin{array}{c}\text { Total } \\
\text { population }\end{array}$ & $\begin{array}{l}\text { Higher } \\
\text { education }\end{array}$ & $\begin{array}{l}\text { Incomplete } \\
\text { higher } \\
\text { education }\end{array}$ & $\begin{array}{l}\text { Specialized } \\
\text { secondary } \\
\text { education }\end{array}$ & $\begin{array}{c}\text { General } \\
\text { secondary } \\
\text { education }\end{array}$ & $\begin{array}{l}\text { Incomplete } \\
\text { secondary } \\
\text { education }\end{array}$ & $\begin{array}{l}\text { Primary } \\
\text { education }\end{array}$ & $\begin{array}{l}\text { Without a } \\
\text { primary } \\
\text { education }\end{array}$ \\
\hline RUSSIAN FEDERATION & 1000 & 133 & 18 & 219 & 285 & 202 & 100 & $\overline{43}$ \\
\hline North & 1000 & 110 & 13 & 237 & 294 & 216 & 95 & 35 \\
\hline Karelian Republic & 1000 & 111 & 16 & 226 & 271 & 226 & 110 & 40 \\
\hline Komi Republic & 1000 & 105 & 14 & 257 & 314 & 207 & 80 & 23 \\
\hline Arkhangel'sk Oblast & 1000 & 107 & 11 & 243 & 266 & 243 & 93 & 37 \\
\hline Nenets Autonomous Okrug & 1000 & 9.8 & 4 & 261 & 221 & 302 & 85 & 29 \\
\hline Vologda Oblast & 1000 & 96 & 13 & 206 & 282 & 223 & 128 & 52 \\
\hline Murmansk Oblast & 1000 & 137 & 13 & 251 & 345 & 172 & 61 & 19 \\
\hline Northwest & 1000 & 190 & 33 & 233 & 273 & 159 & 84 & 28 \\
\hline St.Petersburg City & 1000 & 247 & 48 & 249 & 268 & 126 & 51 & 11 \\
\hline Leningrad Oblast & 1000 & 108 & 11 & 218 & 307 & 197 & 118 & 41 \\
\hline Novgorod Oblast & 1000 & 104 & 11 & 204 & 239 & 238 & 139 & 65 \\
\hline Pskov Oblast & 1000 & 96 & 9 & 195 & 274 & 209 & 156 & 61 \\
\hline Central & 1000 & 178 & 21 & 218 & 265 & 189 & 96 & 33 \\
\hline Bryansk Oblast & 1000 & 95 & 13 & 200 & 296 & 196 & 127 & 73 \\
\hline Vladimir Oblast & 1000 & 107 & 12 & 206 & 289 & 223 & 127 & 36 \\
\hline Ivanovo Oblast & 1000 & 107 & 16 & 211 & 275 & 222 & 131 & 38 \\
\hline Kaluga Oblast & 1000 & 131 & 15 & 235 & 262 & 205 & 111 & 41 \\
\hline Kostroma Oblast & 1000 & 106 & 11 & 214 & 235 & 231 & 146 & 57 \\
\hline Moscow City & 1000 & 299 & 35 & 213 & 258 & 130 & 51 & 14 \\
\hline Moscow Oblast & 1000 & 161 & 19 & 236 & 269 & 198 & 90 & 27 \\
\hline Orel Oblast & 1000 & 115 & 12 & 199 & 267 & 235 & 123 & 49 \\
\hline Ryazan' Oblast & 1000 & 110 & 16 & 217 & 255 & 217 & 124 & 61 \\
\hline Smolensk Oblast & 1000 & 112 & 11 & 224 & 238 & 236 & 125 & 54 \\
\hline Tver' Oblast & 1000 & 104 & 14 & 224 & 254 & 231 & 135 & 38 \\
\hline Tula Oblast & 1000 & 115 & 15 & 212 & 259 & 230 & 122 & 47 \\
\hline Yaroslavl' Oblast & 1000 & 119 & 14 & 210 & 275 & 213 & 127 & 42 \\
\hline Volgo-Vyatka & 1000 & 111 & 13 & 189 & 306 & 206 & 121 & 54 \\
\hline Mari-El Republic & 1000 & 118 & 12 & 181 & 338 & 205 & 104 & 42 \\
\hline Mordvinian Republic & 1000 & 118 & 16 & 162 & 338 & 171 & 106 & 89 \\
\hline Chuvash Republic & 1000 & 105 & 15 & 184 & 324 & 228 & 98 & 46 \\
\hline Kirov Oblast & 1000 & 96 & 11 & 194 & 286 & 224 & 129 & 60 \\
\hline Nizhegorod Oblast & 1000 & 116 & 14 & 197 & 295 & 199 & 132 & 47 \\
\hline Central Chernozem & 1000 & 113 & 14 & 194 & 285 & 199 & 122 & 73 \\
\hline Belgorod Oblast & 1000 & 106 & 12 & 211 & 299 & 180 & 122 & 70 \\
\hline Voronezh Oblast & 1000 & 127 & 15 & 182 & 296 & 189 & 114 & 77 \\
\hline Kursk Oblast & 1000 & 119 & 17 & 182 & 275 & 215 & 126 & 66 \\
\hline Lipetsk Oblast & 1000 & 106 & 11 & 205 & 275 & 214 & 117 & 72 \\
\hline Tambov Oblast & 1000 & 96 & 13 & 200 & 270 & 207 & 137 & 77 \\
\hline Volga & 1000 & 120 & 18 & 218 & 291 & 204 & 102 & 47 \\
\hline Kalmyk Republic & 1000 & 121 & 19 & 223 & 292 & 186 & 101 & 58 \\
\hline Tatarstan Republic & 1000 & 106 & 19 & 197 & 326 & 205 & 102 & 45 \\
\hline Astrakhan' Oblast & 1000 & .. & .. & .. & .. &.. &.. & .. \\
\hline Volgograd Oblast & 1000 & 121 & 17 & 219 & 306 & 195 & 94 & 48 \\
\hline Penza Oblast & 1000 & 107 & 12 & 190 & 278 & 211 & 137 & 65 \\
\hline Samara Oblast & 1000 & 135 & 22 & 241 & 286 & 192 & 88 & 36 \\
\hline Saratov Oblast & 1000 & 141 & 23 & 212 & 275 & 210 & 98 & 41 \\
\hline UI'yanovsk Oblast & 1000 & 107 & 14 & 216 & 276 & 205 & 121 & 61 \\
\hline \multicolumn{9}{|c|}{80} \\
\hline
\end{tabular}


Annex G2: Educational Attainment by Region in Russia , 1994 (persons 15 and older)

\begin{tabular}{lcccccccc}
\hline 1994, per thousand & Total & Higher & Incomplete & Specialized & General & Incomplete & Primary & Without a \\
persons 15 and older & population & education & higher & secondary & secondary & secondary & education & primary \\
& & & education & education & education & education & & education
\end{tabular}

\begin{tabular}{|c|c|c|c|c|c|c|c|c|}
\hline North Caucasus & 1000 & 120 & 16 & 213 & 294 & 203 & 101 & 53 \\
\hline Adygey Republic & 1000 & 102 & 13 & 230 & 265 & 214 & 98 & 78 \\
\hline Dagestan Republic & 1000 & 98 & 14 & 159 & 329 & 228 & 115 & 57 \\
\hline Ingushetia Republic & 1000 & 56 & 20 & 220 & 353 & 174 & 64 & 100 \\
\hline Kabardino-Balkar Republic & 1000 & 121 & 17 & 200 & 321 & 197 & 87 & 57 \\
\hline Karachay-Cherkess Republic & 1000 & 120 & 15 & 180 & 344 & 193 & 80 & 68 \\
\hline North Ossetian Republic & 1000 & 161 & 26 & 230 & 277 & 180 & 78 & 48 \\
\hline Checheniya Republic & 1000 & .. & .. & .. & .. & .. & .. & .. \\
\hline Krasnodar Kray & 1000 & 115 & 12 & 224 & 284 & 207 & 103 & 55 \\
\hline Stavropol' Kray & 1000 & 123 & 13 & 217 & 290 & 193 & 117 & 47 \\
\hline Rostov Oblast & 1000 & 132 & 21 & 221 & 287 & 201 & 94 & 44 \\
\hline Lirals & 1000 & 101 & 14 & 204 & 306 & 220 & 109 & 46 \\
\hline Bashkortostan Republic & 1000 & 91 & 15 & 187 & 337 & 213 & 112 & 45 \\
\hline Udmurt Republic & 1000 & 106 & 20 & 189 & 339 & 202 & 104 & 40) \\
\hline Kurgan Oblast & 1000 & 82 & 10 & 197 & 279 & 224 & 143 & 65 \\
\hline Orenburg Oblast & 1000 & 99 & 15 & 221 & 290 & 217 & 108 & 50 \\
\hline Perm' Oblast & 1000 & 97 & 13 & 197 & 287 & 246 & 114 & 46 \\
\hline Komi-Permyak Aut. Okrug & 1000 & 54 & 6 & 171 & 196 & 324 & 170 & 79 \\
\hline Sverdlovsk Oblast & 1000 & 109 & 14 & 211 & 292 & 229 & 100 & 45 \\
\hline Chelyabinsk Oblast & 1000 & 107 & 13 & 218 & 310 & 200 & 105 & 47 \\
\hline West Siberia & 1000 & 114 & 19 & 231 & 281 & 205 & 104 & 46 \\
\hline Altay Republic & 1000 & 89 & 16 & 204 & 292 & 231 & 115 & 53 \\
\hline Altay Kray & 1000 & 102 & 13 & 211 & 279 & 210 & 124 & 61 \\
\hline Kemerovo Oblast & 1000 & 94 & 16 & 227 & 284 & 223 & 110 & 46 \\
\hline Novosibirsk Oblast & 1000 & 135 & 24 & 229 & 239 & 217 & 108 & 48 \\
\hline Omsk Oblast & 1000 & 117 & 16 & 206 & 285 & 206 & 118 & 52 \\
\hline Tomsk Oblast & 1000 & 140 & 42 & 227 & 273 & 178 & 99 & 41 \\
\hline Tyumen' Oblast & 1000 & 116 & 15 & 279 & 328 & 174 & 64 & 24 \\
\hline Khanty-Mansiy Aut. Okrug & 1000 & 115 & 14 & 306 & 381 & 142 & 34 & 8 \\
\hline Yamal-Nenets Aut. Okrug & 1000 & 126 & 14 & 350 & 365 & 122 & 15 & 8 \\
\hline East Siberia & 1000 & 123 & 21 & 229 & 271 & 222 & 94 & 40 \\
\hline Buryat Republic & 1000 & 138 & 24 & 215 & 265 & 210 & 86 & 58 \\
\hline Tuva Republic & 1000 & 93 & 18 & 227 & 317 & 231 & 78 & 36 \\
\hline Khakass Republic & 1000 & 107 & 12 & 221 & 292 & 215 & 113 & 40 \\
\hline Krasnoyarsk Kray & 1000 & 119 & 28 & 230 & 278 & 203 & 98 & 44 \\
\hline Taymyr Autonomous Okrug & 1000 & 93 & 9 & 263 & 339 & 199 & 63 & 34 \\
\hline Evenki Autonomous Okrug & 1000 & 146 & 19 & 332 & 270 & 149 & 66 & 18 \\
\hline Irkutsk Oblast & 1000 & 134 & 18 & 236 & 268 & 227 & 87 & 30 \\
\hline Ust'-Orda Buryat Aut. Okrug & 1000 & 75 & 4 & 149 & 291 & 290 & 137 & 54 \\
\hline Chita Oblast & 1000 & 111 & 15 & 222 & 248 & 262 & 102 & 40 \\
\hline Aga Buryat Autonomous Okrug & 1000 & 123 & 10 & 160 & 311 & 232 & 114 & 50 \\
\hline Far East & 1000 & 141 & 18 & 262 & 280 & 202 & 72 & 25 \\
\hline Sakha Republic (Yakutia) & 1000 & 125 & 16 & 272 & 345 & 153 & 63 & 26 \\
\hline Jewish Autonomous Oblast & 1000 & 68 & 10 & 214 & 241 & 317 & 115 & 35 \\
\hline Chukotka Autonomous Okrug & 1000 & 167 & 17 & 331 & 333 & 123 & 25 & 4 \\
\hline Primorskiy Kray & 1000 & 146 & 18 & 248 & 268 & 214 & 80 & 26 \\
\hline Khabarovsk Kray & 1000 & 164 & 22 & 257 & 255 & 211 & 66 & 25 \\
\hline Amur Oblast & 1000 & 133 & 15 & 253 & 240 & 231 & 95 & 33 \\
\hline
\end{tabular}




\section{Annex G2: Educational Attainment by Region in Russia , 1994 (persons 15 and older)}

\begin{tabular}{|c|c|c|c|c|c|c|c|c|}
\hline $\begin{array}{l}\text { 1994, per thousand } \\
\text { persons } 15 \text { and older }\end{array}$ & $\begin{array}{c}\text { Total } \\
\text { population }\end{array}$ & $\begin{array}{l}\text { Higher } \\
\text { education }\end{array}$ & $\begin{array}{l}\text { Incomplete } \\
\text { higher } \\
\text { education }\end{array}$ & $\begin{array}{l}\text { Specialized } \\
\text { secondary } \\
\text { education }\end{array}$ & $\begin{array}{c}\text { General } \\
\text { secondary } \\
\text { education }\end{array}$ & $\begin{array}{l}\text { Incomplete } \\
\text { secondary } \\
\text { education }\end{array}$ & $\begin{array}{l}\text { Primary } \\
\text { education }\end{array}$ & $\begin{array}{l}\text { Without a } \\
\text { primary } \\
\text { education }\end{array}$ \\
\hline Kamchatka Oblast & 1000 & 150 & 17 & 316 & 283 & 172 & 47 & 15 \\
\hline Koryak Autonomous Okrug & 1000 & 184 & 14 & 313 & 291 & 135 & 51 & 12 \\
\hline Magadan Oblast & 1000 & 144 & 20 & 285 & 345 & 161 & 39 & 6 \\
\hline Sakhalin Oblast & 1000 & 120 & 14 & 275 & 309 & 194 & 65 & 23 \\
\hline Kaliningrad Oblast & 1000 & 142 & 21 & 260 & 261 & 195 & 85 & 36 \\
\hline
\end{tabular}

.. Not available. 


\begin{tabular}{|c|c|c|c|c|}
\hline & \multicolumn{4}{|c|}{ Pre-schools } \\
\hline & $\begin{array}{l}\text { Number of } \\
\text { institutions }\end{array}$ & Enrollment (ths.) & $\begin{array}{l}\text { Enrollment rates } \\
\text { (percent ages 1-6) }\end{array}$ & $\begin{array}{l}\text { Capacity utilization } \\
\text { (children per } 100 \text { places) }\end{array}$ \\
\hline & 1990 & 1996 & 1996 & 1995 \\
\hline RUSSIAN FEDERATION & 87,944 & $5,100.6$ & 54.9 & 83 \\
\hline North & 4,868 & 269.7 & 74.5 & 85 \\
\hline Karelian Republic & 658 & 35.5 & 74.8 & 93 \\
\hline Komi Republic & 1,050 & 63.1 & 81.0 & 86 \\
\hline Arkhangel'sk Oblast & 1,364 & 68.1 & 72.2 & 91 \\
\hline Nenets Autonomous Okrug & .. & 3.4 & 95.4 & 93 \\
\hline Vologda Oblast & 1,195 & 56.9 & 67.2 & 76 \\
\hline Murmansk Oblast & 601 & 46.1 & 80.0 & 82 \\
\hline Northwest & 3,742 & 264.7 & 64.2 & 84 \\
\hline St.Petersburg City & 1,728 & 158.6 & 67.6 & 91 \\
\hline Leningrad Oblast & 808 & 55.6 & 62.4 & 72 \\
\hline Novgorod Oblast & 555 & 26.8 & 63.9 & 78 \\
\hline Pskov Oblast & 651 & 23.7 & 50.9 & 83 \\
\hline Central & 15,829 & 957.7 & 60.9 & 78 \\
\hline Bryansk Oblast & 905 & 52.6 & 54.2 & 85 \\
\hline Vladimir Oblast & 980 & 63.3 & 70.0 & 91 \\
\hline Ivanovo Oblast & 1,002 & 48.4 & 71.3 & 84 \\
\hline Kaluga Oblast & 640 & 29.9 & 48.7 & 76 \\
\hline Kostroma Oblast & 778 & 33.2 & 69.8 & 83 \\
\hline Moscow City & 2,988 & 251.7 & 58.1 & 73 \\
\hline Moscow Oblast & 2,906 & 217.2 & 66.7 & 76 \\
\hline Orel Oblast & 606 & 27.2 & 49.6 & 90 \\
\hline Ryazan' Oblast & 881 & 37.3 & 51.1 & 78 \\
\hline Smolensk Oblast & 851 & 34.4 & 51.7 & 77 \\
\hline Tver' Oblast & 1,335 & 53.1 & 59.4 & 78 \\
\hline Tula Oblast & 990 & 56.0 & 62.3 & 81 \\
\hline Yaroslavl' Oblast & 967 & 53.4 & 70.3 & 82 \\
\hline Volgo-Vyatka & 5,394 & 314.1 & 61.3 & 82 \\
\hline Mari-El Republic & 499 & 30.1 & 56.3 & 89 \\
\hline Mordvinian Republic & 615 & 29.3 & 50.5 & 78 \\
\hline Chuvash Republic & 677 & 51.6 & 53.2 & 83 \\
\hline Kirov Oblast & 1,504 & 65.6 & 68.8 & 82 \\
\hline Nizhegorod Oblast & 2,099 & 137.5 & 66.1 & 81 \\
\hline Central Chernozem & 4,388 & 208.9 & 44.8 & 83 \\
\hline Belgorod Oblast & 814 & 49.3 & 53.4 & 80 \\
\hline Voronezh Oblast & 1,322 & 62.9 & 43.3 & 89 \\
\hline Kursk Oblast & 818 & 30.1 & 38.2 & 79 \\
\hline Lipetsk Oblast & 665 & 35.8 & 50.1 & 90 \\
\hline Tambov Oblast & 769 & 30.4 & 39.3 & 73 \\
\hline Volga & 9,884 & 591.9 & 53.8 & 84 \\
\hline Kalmyk Republic & 250 & 12.3 & 42.0 & 84 \\
\hline Tatarstan Republic & 2,498 & 172.3 & 63.3 & 93 \\
\hline Astrakhan' Oblast & 524 & 35.9 & 50.7 & 92 \\
\hline Volgograd Oblast & 1,467 & 81.3 & 47.6 & 82 \\
\hline Penza Oblast & 911 & 45.1 & 48.6 & 80 \\
\hline Samara Oblast & 1,571 & 116.7 & 58.7 & 84 \\
\hline Saratov Oblast & 1,742 & 80.5 & 47.6 & 77 \\
\hline Ulyanovsk Oblast & 921 & 47.8 & 49.2 & 79 \\
\hline
\end{tabular}




\begin{tabular}{|c|c|c|c|c|}
\hline & \multicolumn{4}{|c|}{ Pre-schools } \\
\hline & $\begin{array}{l}\text { Number of } \\
\text { institutions }\end{array}$ & Enrollment (ths.) & $\begin{array}{l}\text { Enrollment rates } \\
\text { (percent ages 1-6) }\end{array}$ & $\begin{array}{l}\text { Capacity utilization } \\
\text { (children per } 100 \text { places) }\end{array}$ \\
\hline & 1990 & 1996 & 1996 & $\begin{array}{r}.1995 \\
\end{array}$ \\
\hline North Caucasus & 7,878 & 501.9 & 40.0 & 90 \\
\hline Adygey Republic & 209 & 13.5 & 44.0 & 93 \\
\hline Dagestan Republic & 642 & 49.3 & 21.2 & 98 \\
\hline Ingushetia Republic & & 1.7 & 5.6 & 83 \\
\hline Kabardino-Balkar Republic & 297 & 30.4 & 43.7 & 85 \\
\hline Karachay-Cherkess Republic & 174 & 11.6 & 33.9 & 91 \\
\hline North Ossetian Republic & 288 & 22.6 & 45.0 & 103 \\
\hline Checheniya Republic & 385 & $\ldots$ & .. & .. \\
\hline Krasnodar Kray & 2,261 & 162.5 & 47.4 & 96 \\
\hline Stavropol' Kray & 1,159 & 92.3 & 48.1 & 90 \\
\hline Rostov Oblast & 2,463 & 118.0 & 43.1 & 78 \\
\hline Urals & 14,295 & 825.7 & 60.3 & 83 \\
\hline Bashkortostan Republic & 2,522 & 170.3 & 54.2 & 94 \\
\hline Udmurt Republic & 1,203 & 82.7 & 72.0 & 88 \\
\hline Kurgan Oblast & 1,098 & 37.7 & 50.1 & 78 \\
\hline Orenburg Oblast & 1,523 & 75.7 & 46.9 & 81 \\
\hline Perm' Oblast & 2,423 & 130.4 & 67.0 & 89 \\
\hline Komi-Permyak Aut. Okrug & .. & 7.7 & 62.1 & 90 \\
\hline Sverdlovsk Oblast & 3,241 & 177.8 & 64.5 & 73 \\
\hline Chelyabinsk Oblast & 2,285 & $15 \rrbracket .1$ & 64.7 & 83 \\
\hline West Siberia & 9,429 & 500.0 & 50.8 & 84 \\
\hline Altay Republic & 199 & 6.0 & 33.9 & 88 \\
\hline Altay Kray & 1,831 & 71.0 & 42.9 & 78 \\
\hline Kemerovo Oblast & 1,696 & 96.2 & 50.9 & 90 \\
\hline Novosibirsk Oblast & 1,638 & 74.6 & 45.0 & 81 \\
\hline Omsk Oblast & 1,413 & 68.8 & 44.8 & 77 \\
\hline Tomsk Oblast & 647 & 37.2 & 58.7 & 82 \\
\hline Tyumen' Oblast & 2,005 & 146.2 & 64.1 & 88 \\
\hline Khanty-Mansiy Aut. Okrug &.. & 71.4 & 72.8 & 98 \\
\hline Yamal-Nenets Aut. Okrug & .. & 31.7 & 68.2 & 90 \\
\hline East Siberia & 6,175 & 341.1 & 50.5 & 85 \\
\hline Buryat Republic & 794 & 33.7 & 41.8 & 84 \\
\hline Tuva Republic & 264 & 17.2 & 45.9 & 99 \\
\hline Khakass Republic & 332 & 18.0 & 43.6 & 93 \\
\hline Krasnoyarsk Kray & 1,968 & 111.1 & 52.7 & 87 \\
\hline Taymyr Autonomous Okrug & .. & 2.5 & 75.2 & 90 \\
\hline Evenki Autonomous Okrug & & 1.5 & 79.1 & 72 \\
\hline Irkutsk Oblast & .. & 116.3 & 57.1 & 83 \\
\hline Ust'-Orda Buryat Aut. Okrug & .. & 5.6 & 37.4 & 91 \\
\hline Chita Oblast & 1,019 & 44.8 & 44.5 & 82 \\
\hline Aga Buryat Autonomous Okrug & .. & 2.0 & 25.3 & 83 \\
\hline Far East & 5,423 & 296.1 & 56.8 & 86 \\
\hline Sakha Republic (Yakutia) & 1,047 & 61.7 & 62.8 & 100 \\
\hline Jewish Autonomous Oblast & 183 & 7.6 & 51.0 & 80 \\
\hline Chukotka Autonomous Okrug & 129 & 5.3 & 87.5 & 76 \\
\hline Primorskiy Kray & 1,286 & 78.6 & 53.9 & 84 \\
\hline Khabarovsk Kray & 950 & 52.7 & 50.7 & 84 \\
\hline Amur Oblast & 852 & 37.9 & 52.4 & 78 \\
\hline Kamchatka Oblast & 235 & 18.5 & 75.9 & 84 \\
\hline Koryak Autonomous Okrug & & 2.5 & 94.6 & 71 \\
\hline Magadan Oblast & 250 & 11.3 & 71.6 & 74 \\
\hline Sakhalin Oblast & 491 & 22.5 & 56.7 & 93 \\
\hline Kaliningrad Oblast & 519 & 29.2 & 51.0 & 93 \\
\hline
\end{tabular}

Not available 


\begin{tabular}{|c|c|c|c|}
\hline & \multicolumn{3}{|c|}{ Compulsory schools } \\
\hline & \multirow{2}{*}{$\begin{array}{l}\text { Number of } \\
\text { institutions } \\
\qquad 1995\end{array}$} & $\begin{array}{l}\text { Enrollment } \\
\text { (ths.) }\end{array}$ & $\begin{array}{l}\text { Number of } \\
\text { teachers (ths.) }\end{array}$ \\
\hline & & 1996 & $1994 / 95$ \\
\hline RUSSIAN FEDERATION & 68,400 & 21,103 & $1,508.9$ \\
\hline North & .. & 914 & 64.0 \\
\hline Karelian Republic & 344 & 120 & 8.8 \\
\hline Komi Republic & 604 & 196 & 14.1 \\
\hline Arkhangel'sk Oblast & 852 & 229 & 16.2 \\
\hline Nenets Autonomous Okrug & 47 & 8 & 0.0 \\
\hline Vologda Oblast & 864 & 197 & 13.7 \\
\hline Murmansk Oblast & 254 & 172 & 11.3 \\
\hline Northwest & .. & 996 & 63.6 \\
\hline St.Petersburg City & 713 & 552 & 33.2 \\
\hline Leningrad Oblast & 513 & 233 & 14.3 \\
\hline Novgorod Oblast & 391 & 101 & 7.3 \\
\hline Pskov Oblast & 538 & 110 & 8.8 \\
\hline Central & .. & 3,791 & 261.6 \\
\hline Bryansk Oblast & 885 & 205 & 17.3 \\
\hline Vladimir Oblast & 617 & 217 & 14.2 \\
\hline Ivanovo Oblast & 544 & 162 & 10.7 \\
\hline Kaluga Oblast & 568 & 148 & 11.8 \\
\hline Kostroma Oblast & 563 & 110 & 9.2 \\
\hline Moscow City & 1,474 & 1,056 & 63.6 \\
\hline Moscow Oblast & 1,652 & 833 & 51.2 \\
\hline Orel Oblast & 647 & 118 & 10.2 \\
\hline Ryazan' Oblast & 839 & 168 & 13.6 \\
\hline Smolensk Oblast & 696 & 159 & 13.8 \\
\hline Tver' Oblast & 1,088 & 209 & 16.5 \\
\hline Tula Oblast & 769 & 219 & 15.9 \\
\hline Yaroslavl' Oblast & 607 & 187 & 13.6 \\
\hline Volgo-Vyatka & .. & 1,199 & 92.0 \\
\hline Mari-El Republic & 433 & 128 & 10.1 \\
\hline Mordvinian Republic & 826 & 139 & 13.5 \\
\hline Chuvash Republic & 709 & 218 & 17.6 \\
\hline Kirov Oblast & 1,037 & 245 & 18.7 \\
\hline Nizhegorod Oblast & 1,542 & 469 & 32.2 \\
\hline Central Chernozem & .. & 1,045 & 87.1 \\
\hline Belgorod Oblast & 834 & 209 & 17.1 \\
\hline Voronezh Oblast & 1,224 & 325 & 26.2 \\
\hline Kursk Oblast & 946 & 180 & 16.2 \\
\hline Lipetsk Oblast & 716 & 166 & 13.6 \\
\hline Tambov Oblast & 870 & 165 & 14.2 \\
\hline Volga & .. & 2,399 & 180.9 \\
\hline Kalmyk Republic & 253 & 59 & 5.3 \\
\hline Tatarstan Republic & 2,495 & 560 & 47.7 \\
\hline Astrakhan' Oblast & 392 & 154 & 10.7 \\
\hline Volgograd Oblast & 1,379 & 373 & 26.0 \\
\hline Penza Oblast & 953 & 207 & 16.5 \\
\hline Samara Oblast & 1,119 & 446 & 30.9 \\
\hline Saratov Oblast & 1,501 & 384 & 28.0 \\
\hline Ul'yanovsk Oblast & 740 & 216 & 15.8 \\
\hline
\end{tabular}


Annex G3b: Selected Data on the Education System by Region in Russia

\begin{tabular}{|c|c|c|c|}
\hline & \multicolumn{3}{|c|}{ Compulsory schools } \\
\hline & \multirow{2}{*}{$\begin{array}{l}\text { Number of } \\
\text { institutions } \\
\qquad 1995\end{array}$} & $\begin{array}{l}\text { Enrollment } \\
\text { (ths.) }\end{array}$ & $\begin{array}{l}\text { Number of } \\
\text { teachers (ths.) }\end{array}$ \\
\hline & & 1996 & $1994 / 95$ \\
\hline North Caucasus & & 2,778 & 182.9 \\
\hline Adygey Republic & 173 & 67 & 5.6 \\
\hline Dagestan Republic & 1,615 & 413 & 38.3 \\
\hline Ingushetia Republic & 93 & 89 & 0.0 \\
\hline Kabardino-Balkar Republic & 253 & 139 & 10.2 \\
\hline Karachay-Cherkess Republic & 188 & 74 & 6.0 \\
\hline North Ossetian Republic & 220 & 104 & 8.5 \\
\hline Checheniya Republic & .. & 174 & 0.0 \\
\hline Krasnodar Kray & 1,407 & 721 & 48.9 \\
\hline Stavropol' Kray & 752 & 390 & 24.5 \\
\hline Rostov Oblast & 1,894 & 607 & 40.9 \\
\hline Urals & .. & 3,004 & 215.9 \\
\hline Bashkortostan Republic & 3,334 & 658 & 55.2 \\
\hline Udmurt Republic & 908 & 263 & 19.5 \\
\hline Kurgan Oblast & 928 & 167 & 13.0 \\
\hline Orenburg Oblast & 1,649 & 352 & 26.9 \\
\hline Perm' Oblast & 1,524 & 410 & 30.1 \\
\hline Komi-Permyak Aut. Okrug & 195 & 28 & 0.0 \\
\hline Sverdlovsk Oblast & 1,551 & 644 & 39.8 \\
\hline Chelyabinsk Oblast & 1,351 & 510 & 31.5 \\
\hline West Siberia & .. & 2,048 & 169.0 \\
\hline Altay Republic & 209 & 39 & 3.9 \\
\hline Altay Kray & 1,611 & 426 & 34.3 \\
\hline Kemerovo Oblast & 1,216 & 450 & 29.3 \\
\hline Novosibirsk Oblast & 1,559 & 409 & 28.5 \\
\hline Omsk Oblast & 1,486 & 356 & 25.0 \\
\hline Tomsk Oblast & 516 & 152 & 11.5 \\
\hline Tyumen Oblast & 1,573 & 216 & 36.5 \\
\hline Khanty-Mansiy Aut. Okrug & 401 & 250 & 0.0 \\
\hline Yamal-Nenets Aut. Okrug & 144 & 92 & 0.0 \\
\hline East Siberia & .. & 1,433 & 102.0 \\
\hline Buryat Republic & 619 & 196 & 13.9 \\
\hline Tuva Republic & 166 & 62 & 5.4 \\
\hline Khakass Republic & 283 & 97 & 6.4 \\
\hline Krasnoyarsk Kray & 1,723 & 455 & 32.0 \\
\hline Taymyr Autonomous Okrug & 31 & 8 & 0.0 \\
\hline Evenki Autonomous Okrug & 28 & 4 & 0.0 \\
\hline Irkutsk Oblast & 1,432 & 420 & 30.2 \\
\hline Ust'-Orda Buryat Aut. Okrug & 239 & 30 & 0.0 \\
\hline Chita Oblast & 782 & 203 & 15.2 \\
\hline Aga Buryat Autonomous Okrug & 50 & 19 & 0.0 \\
\hline Far East & .. & 1,186 & 81.1 \\
\hline Sakha Republic (Yakutia) & 718 & 193 & 18.3 \\
\hline Jewish Autonomous Oblast & 111 & 36 & 2.0 \\
\hline Chukotka Autonomous Okrug & 74 & 17 & 1.4 \\
\hline Primorskiy Kray & 738 & 335 & 20.2 \\
\hline Khabarovsk Kray & 504 & 237 & 14.9 \\
\hline Amur Oblast & 560 & 163 & 10.1 \\
\hline Kamchatka Oblast & 143 & 58 & 4.5 \\
\hline Koryak Autonomous Okrug & 30 & 6 & 0.0 \\
\hline Magadan Oblast & 120 & 43 & 3.0 \\
\hline Sakhalin Oblast & 233 & 104 & 6.7 \\
\hline Kaliningrad Oblast & 295 & 128 & 8.8 \\
\hline
\end{tabular}


Annex G3c: Selected Data on the Education System by Region in Russia

\begin{tabular}{|c|c|c|c|c|c|}
\hline & \multicolumn{3}{|c|}{ Vocational/Professional-Technical Institutions } & \multicolumn{2}{|c|}{ Tekhnikums (Secondary Professional Inst.) } \\
\hline & \multirow[t]{2}{*}{$\begin{array}{l}\text { Number of } \\
\text { institutions }\end{array}$} & \multicolumn{2}{|c|}{$\begin{array}{l}\text { Enrollment } \\
\text { (ths.) }\end{array}$} & $\begin{array}{l}\text { Number of } \\
\text { institutions }\end{array}$ & $\begin{array}{l}\text { Number of } \\
\text { students (ths.) }\end{array}$ \\
\hline & & 1995 & 1995 & $1995 / 96$ & $1995 / 96$ \\
\hline RUSSIAN FEDERATION & & 4,166 & $1,689.5$ & 2,612 & $1,923.3$ \\
\hline North & & 211 & 80.2 & 99 & 67.8 \\
\hline Karelian Republic & & 21 & 8.1 & 16 & 11.7 \\
\hline Komi Republic & & 50 & 17.5 & 20 & 14.3 \\
\hline Arkhangel'sk Oblast & & 61 & 23.7 & 27 & 17.1 \\
\hline Nenets Autonomous Okrug & & 1 & 0.5 & 2 & 0.5 \\
\hline Vologda Oblast & & 53 & 19.8 & 25 & 16.0 \\
\hline Murmansk Oblast & & 26 & 11.1 & 11 & 8.7 \\
\hline Northwest & & 222 & 102.1 & 128 & 92.5 \\
\hline St.Petersburg City & & 110 & 61.6 & 83 & 67.1 \\
\hline Leningrad Oblast & & 51 & 22.6 & 15 & 7.5 \\
\hline Novgorod Oblast & & 29 & 7.1 & 14 & 9.3 \\
\hline Pskov Oblast & & 32 & 10.8 & 16 & 8.6 \\
\hline Central & & 792 & 304.5 & 573 & 370.0 \\
\hline Bryansk Oblast & & 41 & 17.4 & 28 & 21.2 \\
\hline Vladimir Oblast & & 60 & 23.3 & 32 & 19.9 \\
\hline Ivanovo Oblast & & 44 & 15.4 & 31 & 16.5 \\
\hline Kaluga Oblast & & 39 & 11.8 & 26 & 14.7 \\
\hline Kostroma Oblast & & 34 & 11.0 & 19 & 10.9 \\
\hline Moscow City & & 172 & 74.6 & 147 & 104.9 \\
\hline Moscow Oblast & & 128 & 52.1 & 106 & 63.4 \\
\hline Orel Oblast & & 34 & 12.0 & 19 & 13.4 \\
\hline Ryazan' Oblast & & 42 & 15.8 & 29 & 18.2 \\
\hline Smolensk Oblast & & 37 & 14.6 & 27 & 16.2 \\
\hline Tver' Oblast & & 59 & 19.7 & 40 & 22.3 \\
\hline Tula Oblast & & 54 & 19.3 & 41 & 28.7 \\
\hline Yarosiavl' Oblast & & 48 & 17.5 & 28 & 19.7 \\
\hline Volgo-Vyatka & & 257 & 106.7 & 153 & 110.9 \\
\hline Mari-El Republic & & 32 & 10.7 & 14 & 8.6 \\
\hline Mordvinian Republic & & 43 & 13.2 & 21 & 12.8 \\
\hline Chuvash Republic & & 32 & 17.3 & 28 & 20.3 \\
\hline Kirov Oblast & & 53 & 19.3 & 31 & 18.2 \\
\hline Nizhegorod Oblast & & 97 & 46.2 & 59 & 51.0 \\
\hline Central Chernozem & & 212 & 89.8 & 146 & $1[4.3$ \\
\hline Belgorod Oblast & & 37 & 20.4 & 26 & 22.1 \\
\hline Voronezh Oblast & & 60 & 22.1 & 44 & 38.8 \\
\hline Kursk Oblast & & 42 & 16.9 & 29 & 17.4 \\
\hline Lipetsk Oblast & & 37 & 16.6 & 22 & 17.3 \\
\hline Tambov Oblast & & 36 & 13.8 & 25 & 18.7 \\
\hline Volga & & 485 & 188.3 & 301 & 249.2 \\
\hline Kalmyk Republic & & 13 & 3.4 & 6 & 4.3 \\
\hline Tatarstan Republic & & 115 & 46.5 & 67 & 53.8 \\
\hline Astrakhan' Oblast & & 34 & 11.6 & 21 & 17.1 \\
\hline Volgograd Oblast & & 73 & 26.8 & 42 & 40.9 \\
\hline Penza Oblast & & 42 & 16.8 & 32 & 22.2 \\
\hline Samara Oblast & & 84 & 34.8 & 62 & 51.9 \\
\hline Saratov Oblast & & 81 & 33.4 & 48 & 39.7 \\
\hline Ul'yanovsk Oblast & & 40 & 15.0 & 23 & 19.3 \\
\hline
\end{tabular}


Annex G3c: Selected Data on the Education System by Region in Russia

\begin{tabular}{|c|c|c|c|c|c|}
\hline & \multicolumn{3}{|c|}{ Vocational/Professional-Technical Institutions } & \multicolumn{2}{|c|}{ Tekhnikums (Secondary Professional Inst.) } \\
\hline & \multirow[t]{2}{*}{$\begin{array}{l}\text { Number of } \\
\text { institutions }\end{array}$} & \multicolumn{2}{|c|}{$\begin{array}{l}\text { Enrollment } \\
\text { (ths.) }\end{array}$} & \multirow[t]{2}{*}{$\begin{array}{l}\text { Number of } \\
\text { institutions }\end{array}$} & $\begin{array}{l}\text { Number of } \\
\text { students (ths.) }\end{array}$ \\
\hline & & 1995 & 1995 & & $1995 / 96$ \\
\hline North Caucasus & & 349 & 157.6 & 226 & 193.2 \\
\hline Adygey Republic & & 12 & 4.1 & 4 & 5.1 \\
\hline Dagestan Republic & & 29 & 13.3 & 27 & 17.4 \\
\hline Ingushetia Republic & & 3 & 0.9 & 2 & 0.9 \\
\hline Kabardino-Balkar Republic & & 20 & 9.7 & 8 & 7.4 \\
\hline Karachay-Cherkess Republic & & 8 & 4.9 & 7 & 5.3 \\
\hline North Ossetian Republic & & 16 & 6.5 & 15 & 10.8 \\
\hline Checheniya Republic & & 18 & 6.2 & 8 & 4.7 \\
\hline Krasnodar Kray & & 75 & 30.6 & 54 & 48.9 \\
\hline Stavropol' Kray & & 54 & 31.7 & 27 & 26.2 \\
\hline Rostov Oblast & & 114 & 49.7 & 74 & 66.5 \\
\hline Urals & & 659 & 287.3 & 393 & 301.8 \\
\hline Bashkortostan Republic & & 137 & 63.0 & 76 & 63.5 \\
\hline Udmurt Republic & & 47 & 19.2 & 30 & 20.9 \\
\hline Kurgan Oblast & & 36 & 13.6 & 22 & 14.7 \\
\hline Orenburg Oblast & & 72 & 29.7 & 45 & 38.7 \\
\hline Perm' Oblast & & 107 & 46.7 & 62 & 39.7 \\
\hline Komi-Permyak Aut. Okrug & & .. & .. & 4 & 2.1 \\
\hline Sverdlovsk Oblast & & 133 & 62.8 & 90 & 67.2 \\
\hline Chelyabinsk Oblast & & 127 & 52.3 & 68 & 57.1 \\
\hline West Siberia & & 456 & 176.5 & 260 & 193.4 \\
\hline Altay Republic & & 94 & 2.2 & 5 & 3.0 \\
\hline Altay Kray & &.. & 34.7 & 44 & 29.9 \\
\hline Kemerovo Oblast & & 86 & 40.1 & 58 & 43.6 \\
\hline Novosibirsk Oblast & & 92 & 29.2 & 55 & 37.7 \\
\hline Omsk Oblast & & 88 & 26.9 & 39 & 35.4 \\
\hline Tomsk Oblast & & 74 & 15.7 & 21 & 15.2 \\
\hline Tyumen' Oblast & & 41 & 27.7 & 38 & 28.6 \\
\hline Khanty-Mansiy Aut. Okrug & & .. & .. & 10 & 7.6 \\
\hline Yamal-Nenets Aut. Okrug & & .. & .. & 8 & 5.7 \\
\hline East Siberia & & 263 & 104.1 & 182 & 125.4 \\
\hline Buryat Republic & & 43 & 15.5 & 20 & 13.5 \\
\hline Tuva Republic & & 11 & 3.8 & 6 & 3.9 \\
\hline Khakass Republic & & 17 & 7.2 & 8 & 6.8 \\
\hline Krasnoyarsk Kray & & 93 & 33.1 & 71 & 48.3 \\
\hline Taymyr Autonomous Okrug & & 1 & .. & 1 & 0.4 \\
\hline Evenki Autonomous Okrug & & .. & 0.9 & 1 & 0.1 \\
\hline Irkutsk Oblast & & 67 & 32.4 & 55 & 37.3 \\
\hline Ust'-Orda Buryat Aut. Okrug & & 3 & 1.1 & 2 & 0.4 \\
\hline Chita Oblast & & 32 & 12.1 & 22 & 15.6 \\
\hline Aga Buryat Autonomous Okrug & & .. & .. & 1 & 0.5 \\
\hline Far East & & 236 & 82.5 & 137 & 94.3 \\
\hline Sakha Republic (Yakutia) & & 32 & 8.7 & 20 & 10.6 \\
\hline Jewish Autonomous Oblast & & 8 & 2.9 & 6 & 4.0 \\
\hline Chukotka Autonomous Okrug & & 4 & 1.0 & 2 & 0.7 \\
\hline Primorskiy Kray & & 65 & 23.7 & 35 & 28.8 \\
\hline Khabarovsk Kray & & 48 & 18.3 & 28 & 21.9 \\
\hline Amur Oblast & & 31 & 12.8 & 23 & 16.4 \\
\hline Kamchatka Oblast & & 16 & 4.5 & 7 & 4.2 \\
\hline Koryak Autonomous Okrug & & 1 & 0.2 & 1 & 0.0 \\
\hline Magadan Oblast & & 10 & 2.7 & 6 & 2.4 \\
\hline Sakhalin Oblast & & 22 & 7.9 & 10 & 5.3 \\
\hline Kaliningrad Oblast & & 24 & 9.9 & 13 & 10.5 \\
\hline
\end{tabular}

Not available 


\begin{tabular}{|c|c|c|c|}
\hline & \multicolumn{3}{|c|}{ Higher Educational Instituions (Universities) } \\
\hline & \multirow[t]{2}{*}{$\begin{array}{l}\text { Number of } \\
\text { institutions }\end{array}$} & \multicolumn{2}{|c|}{$\begin{array}{l}\text { Enrollment } \\
\text { (ths.) }\end{array}$} \\
\hline & & 1995 & 1995 \\
\hline RUSSIAN FEDERATION & & 569 & $2,655.2$ \\
\hline North & & 18 & 66.4 \\
\hline Karelian Republic & & 4 & 10.4 \\
\hline Komi Republic & & 4 & 12.9 \\
\hline Arkhangel'sk Oblast & & 3 & 16 \\
\hline Nenets Autonomous Okrug & & .. & .. \\
\hline Vologda Oblast & & 5 & 18.9 \\
\hline Murmansk Oblast & & 2 & 8.2 \\
\hline Northwest & & 47 & 224.9 \\
\hline St.Petersburg City & & 42 & 205.6 \\
\hline Leningrad Oblast & & .. & .. \\
\hline Novgorod Oblast & & 2 & 10.3 \\
\hline Pskov Oblast & & 3 & 9 \\
\hline Central & & 142 & 706 \\
\hline Bryansk Oblast & & 4 & 15.7 \\
\hline Vladimir Oblast & & 3 & 15.8 \\
\hline Ivanovo Oblast & & 8 & 25 \\
\hline Kaluga Oblast & & 2 & 11 \\
\hline Kostroma Oblast & & 3 & 11.9 \\
\hline Moscow City & & 84 & 450.8 \\
\hline Moscow Oblast & & 12 & 69.1 \\
\hline Orel Oblast & & 5 & 17.9 \\
\hline Ryazan' Oblast & & 4 & 16.6 \\
\hline Smolensk Oblast & & 4 & 11.9 \\
\hline Tver' Oblast & & 4 & 18.8 \\
\hline Tula Oblast & & 2 & 19 \\
\hline Yaroslavl' Oblast & & 7 & 22.5 \\
\hline Volgo-Vyatka & & 25 & 133.2 \\
\hline Mari-El Republic & & 3 & 13.5 \\
\hline Mordvinian Republic & & 2 & 24.3 \\
\hline Chuvash Republic & & 3 & 20.7 \\
\hline Kirov Oblast & & 4 & 16.4 \\
\hline Nizhegorod Oblast & & 13 & 58.3 \\
\hline Central Chernozem & & 25 & 124.3 \\
\hline Belgorod Oblast & & 4 & 22.2 \\
\hline Voronezh Oblast & & 10 & 50.4 \\
\hline Kursk Oblast & & 4 & 20.8 \\
\hline Lipetsk Oblast & & 3 & 12.8 \\
\hline Tambov Oblast & & 4 & 18.1 \\
\hline Volga & & 64 & 287.5 \\
\hline Kalmyk Republic & & 1 & .5 .5 \\
\hline Tatarstan Republic & & 16 & 65.2 \\
\hline Astrakhan' Oblast & & 5 & 13.2 \\
\hline Volgograd Oblast & & 9 & 41.2 \\
\hline Penza Oblast & & 4 & 22.2 \\
\hline Samara Oblast & & 13 & 66.4 \\
\hline Saratov Oblast & & 12 & 53.3 \\
\hline Ul'yanovsk Oblast & & 4 & 20.5 \\
\hline
\end{tabular}




\begin{tabular}{|c|c|c|c|}
\hline & \multicolumn{3}{|c|}{ Higher Educational Instituions (Universities) } \\
\hline & \multirow[t]{2}{*}{$\begin{array}{l}\text { Number of } \\
\text { institutions }\end{array}$} & \multicolumn{2}{|c|}{$\begin{array}{l}\text { Enrollment } \\
\text { (ths.) }\end{array}$} \\
\hline & & 1995 & 1995 \\
\hline North Caucasus & & 56 & 257.5 \\
\hline Adygey Republic & & 2 & 7.4 \\
\hline Dagestan Republic & & 6 & 30.9 \\
\hline Ingushetia Republic & & 1 & 0.9 \\
\hline Kabardino-Balkar Republic & & 3 & 13.6 \\
\hline Karachay-Cherkess Republic & & 2 & 6.9 \\
\hline North Ossetian Republic & & 5 & 19 \\
\hline Checheniya Republic & & 3 & 13.2 \\
\hline Krasnodar Kray & & 9 & 49.3 \\
\hline Stavropol' Kray & & 6 & 29.4 \\
\hline Rostov Oblast & & 19 & 86.9 \\
\hline Urals & & 61 & 298.9 \\
\hline Bashkortostan Republic & & 11 & 51.6 \\
\hline Udmurt Republic & & 5 & 27.6 \\
\hline Kurgan Oblast & & 4 & 13.3 \\
\hline Orenburg Oblast & & 5 & 28.6 \\
\hline Perm' Oblast & & 8 & 40.9 \\
\hline Komi-Permyak Aut. Okrug & & .. & .. \\
\hline Sverdlovsk Oblast & & 16 & 82 \\
\hline Chelyabinsk Oblast & & 12 & 54.9 \\
\hline West Siberia & & 60 & 273.5 \\
\hline Altay Republic & & 1 & 4.2 \\
\hline Altay Kray & & 7 & 39.7 \\
\hline Kemerovo Oblast & & 9 & 41.1 \\
\hline Novosibirsk Oblast & & 16 & 70.5 \\
\hline Omsk Oblast & & 9 & 41.4 \\
\hline Tomsk Oblast & & 7 & 36.9 \\
\hline Tyumen' Oblast & & 11 & 39.7 \\
\hline Khanty-Mansiy Aut. Okrug & & 3 & 3.9 \\
\hline Yamal-Nenets Aut. Okrug & & .. & .. \\
\hline East Siberia & & 33 & 154.6 \\
\hline Buryat Republic & & 4 & 19.6 \\
\hline Tuva Republic & & 1 & 3 \\
\hline Khakass Republic & & 1 & 6.4 \\
\hline Krasnoyarsk Kray & & 13 & 60.1 \\
\hline Taymyr Autonomous Okrug & & .. & .. \\
\hline Evenki Autonomous Okrug & & .. & .. \\
\hline Irkutsk Oblast & & 10 & 53.8 \\
\hline Ust'-Orda Buryat Aut. Okrug & & .. & .. \\
\hline Chita Oblast & & 4 & 11.7 \\
\hline Aga Buryat Autonomous Okrug & & .. & .. \\
\hline Far East & & 35 & 116 \\
\hline Sakha Republic (Yakutia) & & 3 & 10.8 \\
\hline Jewish Autonomous Oblast & & 1 & 1.6 \\
\hline Chukotka Autonomous Okrug & & .. & .. \\
\hline Primorskiy Kray & & 11 & 39.7 \\
\hline Khabarovsk Kray & & 10 & 38.4 \\
\hline Amur Oblast & & 4 & 14.9 \\
\hline Kamchatka Oblast & & 3 & 4.3 \\
\hline Koryak Autonomous Okrug & & .. & .. \\
\hline Magadan Oblast & & 1 & 2.8 \\
\hline Sakhalin Oblast & & 2 & 3.5 \\
\hline Kaliningrad Oblast & & 3 & 12.4 \\
\hline
\end{tabular}


Annex G3e: Selected Data on the Education System by Region in Russia

\begin{tabular}{|c|c|c|c|}
\hline & \multicolumn{2}{|c|}{ Salaries of education workers } & \multirow{2}{*}{$\begin{array}{c}\text { Share of students in } \\
\text { compulsory schools studying } \\
\text { on a second shift } \\
\end{array}$} \\
\hline & $\begin{array}{l}\text { Average monthly wage } \\
\text { of education workers }\end{array}$ & $\begin{array}{l}\text { Education wages as } \\
\text { share of all workers }\end{array}$ & \\
\hline & 1995 & 1995 & $1995 / 96$ \\
\hline RUSSIAN FEDERATION & 309,242 & 65.5 & 24.8 \\
\hline North & 420,466 & 60.1 & 23.2 \\
\hline Karelian Republic & 377,601 & 62.5 & 17.8 \\
\hline Komi Republic & 466,645 & 53.2 & 23.7 \\
\hline Arkhangel'sk Oblast & 400,899 & 65.3 & 20.0 \\
\hline Nenets Autonomous Okrug & .. & .. & 11.2 \\
\hline Vologda Oblast & 330,850 & 58.9 & 21.3 \\
\hline Murmansk Oblast & 539,935 & 63.4 & 33.2 \\
\hline Northwest & 280,393 & 67.2 & 15.4 \\
\hline St.Petersburg City & 299,784 & 67.6 & 12.2 \\
\hline Leningrad Oblast & 248,630 & 60.8 & 20.3 \\
\hline Novgorod Oblast & 253,331 & 70.1 & 19.1 \\
\hline Pskov Oblast & 240,744 & 77.7 & 18.2 \\
\hline Central & 288,012 & 65.3 & 20.9 \\
\hline Bryansk Oblast & 214,419 & 74.3 & 25.1 \\
\hline Vladimir Oblast & 232,031 & 68.3 & 27.6 \\
\hline Ivanovo Oblast & 224,456 & 73.7 & 26.4 \\
\hline Kaluga Oblast & 243,955 & 70.0 & 23.9 \\
\hline Kostroma Oblast & 235,099 & 63.7 & 24.7 \\
\hline Moscow City & 388,456 & 66.5 & 14.6 \\
\hline Moscow Oblast & 267,190 & 64.3 & 23.1 \\
\hline Orel Oblast & 220,183 & 73.4 & 21.4 \\
\hline Ryazan' Oblast & 214,008 & 59.8 & 18.9 \\
\hline Smolensk Oblast & 236,054 & 77.3 & 25.5 \\
\hline Tver' Oblast & 222,832 & 59.2 & 22.1 \\
\hline Tula Oblast & 241,096 & 67.3 & 19.1 \\
\hline Yaroslavl' Oblast & 274,996 & 72.2 & 24.0 \\
\hline Volgo-Vyatka & 241,234 & 71.7 & 20.6 \\
\hline Mari-El Republic & 213,744 & 84.0 & 21.0 \\
\hline Mordvinian Republic & 216,757 & 78.4 & 16.6 \\
\hline Chuvash Republic & 201,590 & 79.7 & 15.8 \\
\hline Kirov Oblast & 242,786 & 72.6 & 20.7 \\
\hline Nizhegorod Oblast & 272,801 & 68.6 & 23.9 \\
\hline Central Chernozem & 231,371 & 70.1 & 21.1 \\
\hline Belgorod Oblast & 237,462 & 64.9 & 18.0 \\
\hline Voronezh Oblast & 214,447 & 72.8 & 23.3 \\
\hline Kursk Oblast & 232,036 & 72.4 & 17.9 \\
\hline Lipetsk Oblast & 261,566 & 64.7 & 25.7 \\
\hline Tambov Oblast & 226,046 & 78.5 & 19.6 \\
\hline Volga & 270,388 & 69.3 & 23.4 \\
\hline Kalmyk Republic & 230,478 & 94.5 & 15.2 \\
\hline Tatarstan Republic & 303,793 & 70.9 & 24.0 \\
\hline Astrakhan' Oblast & 241,082 & 66.6 & 31.4 \\
\hline Volgograd Oblast & 263,702 & 68.0 & 23.1 \\
\hline Penza Oblast & 223,510 & 85.6 & 20.2 \\
\hline Samara Oblast & 330,150 & 62.1 & 27.1 \\
\hline Saratov Oblast & 215,858 & 75.8 & 20.1 \\
\hline Ul'yanovsk Oblast & 227,560 & 69.9 & 20.6 \\
\hline
\end{tabular}


Annex G3e: Selected Data on the Education System by Region in Russia

\begin{tabular}{|c|c|c|c|}
\hline & \multicolumn{2}{|c|}{ Salaries of education workers } & \multirow{2}{*}{$\begin{array}{c}\text { Share of students in } \\
\text { compulsory schools studying } \\
\text { on a second shift }\end{array}$} \\
\hline & $\begin{array}{l}\text { Average monthly wage } \\
\text { of education workers }\end{array}$ & $\begin{array}{l}\text { Education wages as } \\
\text { share of all workers }\end{array}$ & \\
\hline & 1995 & 1995 & $1995 / 96$ \\
\hline North Caucasus & 219,045 & 73.0 & 28.1 \\
\hline Adygey Republic & 228,662 & 77.2 & 27.4 \\
\hline Dagestan Republic & 211,833 & 123.1 & 30.7 \\
\hline Ingushetia Republic & 219,696 & 94.1 & 39.8 \\
\hline Kabardino-Balkar Republic & 230,436 & 97.3 & 29.6 \\
\hline Karachay-Cherkess Republic & 189,402 & 72.8 & 24.3 \\
\hline North Ossetian Republic & 184,226 & 75.3 & 22.1 \\
\hline Checheniya Republic & .. & .. & .. \\
\hline Krasnodar Kray & 231,092 & 71.2 & 29.9 \\
\hline Stavropol' Kray & 226,840 & 72.6 & 25.9 \\
\hline Rostov Oblast & 212,936 & 64.8 & 25.9 \\
\hline Urals & 288,435 & 65.0 & 27.3 \\
\hline Bashkortostan Republic & 272,119 & 65.4 & 27.5 \\
\hline Udmurt Republic & 253,870 & 72.0 & 27.3 \\
\hline Kurgan Oblast & 247,030 & 72.8 & 22.1 \\
\hline Orenburg Oblast & 265,423 & 63.5 & 22.9 \\
\hline Perm' Oblast & 296,047 & 62.9 & 27.4 \\
\hline Komi-Permyak Aut. Okrug & .. & .. & 11.8 \\
\hline Sverdlovsk Oblast & 321,868 & 64.1 & 27.8 \\
\hline Chelyabinsk Oblast & 303,687 & 65.5 & 30.9 \\
\hline West Siberia & 379,747 & 59.5 & 29.9 \\
\hline Altay Republic & 321,109 & 98.8 & 27.6 \\
\hline Altay Kray & 265,324 & 79.9 & 26.0 \\
\hline Kemerovo Oblast & 370,054 & 55.1 & 35.4 \\
\hline Novosibirsk Oblast & 278,426 & 71.1 & 25.1 \\
\hline Omsk Oblast & 274,935 & 69.4 & 26.2 \\
\hline Tomsk Oblast & 340,301 & 62.3 & 28.2 \\
\hline Tyumen' Oblast & 650,359 & 56.0 & 35.0 \\
\hline Khanty-Mansiy Aut. Okrug & .. & .. & 41.2 \\
\hline Yamal-Nenets Aut. Okrug & .. & .. & 37.4 \\
\hline East Siberia & 400,990 & 60.1 & 26.5 \\
\hline Buryat Republic & 289,323 & 57.4 & 20.9 \\
\hline Tuva Republic & 299,069 & 75.8 & 30.0 \\
\hline Khakass Republic & 348,418 & 62.8 & 29.7 \\
\hline Krasnoyarsk Kray & 449,296 & 59.5 & 23.1 \\
\hline Taymyr Autonomous Okrug & .. & .. & 33.3 \\
\hline Evenki Autonomous Okrug & .. & .. & 17.4 \\
\hline Irkutsk Oblast & 462,785 & 62.7 & 31.3 \\
\hline Ust'-Orda Buryat Aut. Okrug & .. & .. & 13.0 \\
\hline Chita Oblast & 311,394 & 61.8 & 26.8 \\
\hline Aga Buryat Autonomous Okrug & .. & .. & 21.9 \\
\hline Far East & 513,388 & 63.6 & 29.9 \\
\hline Sakha Republic (Yakutia) & 702,558 & 60.9 & 26.5 \\
\hline Jewish Autonomous Oblast & 350,720 & 70.5 & 25.1 \\
\hline Chukotka Autonomous Okrug & 861,560 & 51.2 & 19.2 \\
\hline Primorskiy Kray & 394,695 & 60.9 & 32.4 \\
\hline Khabarovsk Kray & 453,211 & 67.7 & 32.0 \\
\hline Amur Oblast & 422,055 & 69.0 & 26.8 \\
\hline Kamchatka Oblast & 690,798 & 56.9 & 29.3 \\
\hline Koryak Autonomous Okrug & .. & .. & 8.7 \\
\hline Magadan Oblast & 743,345 & 67.1 & 27.9 \\
\hline Sakhalin Oblast & 520,805 & 59.7 & 32.5 \\
\hline Kaliningrad Oblast & 262,517 & 70.0 & 28.5 \\
\hline .. Not available & 92 & & \\
\hline
\end{tabular}


Annex G4: Selected Data on Education Financy by Region in Russia

\begin{tabular}{|c|c|c|c|c|c|c|c|c|c|c|c|c|}
\hline & $\begin{array}{c}\text { Gross Regional } \\
\text { Product per }\end{array}$ & Total revenues & $\begin{array}{c}\text { Total } \\
\text { expenditures }\end{array}$ & Budget Deficit & & Expend & ditures on $\mathbf{E}$ & Education, 1 & & & & \\
\hline & & & & & Total & Salaries & Medicine & Meals & $\begin{array}{l}\text { Capital } \\
\text { investments }\end{array}$ & Civil works & Ôther & $\begin{array}{l}\text { Education } \\
\text { expenses as } \\
\text { share of } \\
\text { total }\end{array}$ \\
\hline RUSSIAN FEDERATION & $9,562.2$ & $324,213,829$ & $342,812,547$ & $-19,874,740$ & $72,384,747$ & $28,491,952$ & 33,158 & $5,534,065$ & 972,687 & $2,744,533$ & $34,608,352$ & 21.1 \\
\hline North & .. & $13,457,234$ & $14,712,913$ & .. & $3,722,172$ & $1,655,348$ & 2,767 & 267,016 & 26,510 & 107,746 & $1,662,785$ & 25.3 \\
\hline Karelian Republic & $10,245.5$ & $1,756,486$ & $1,903,389$ & $-152,029$ & 471,729 & 243,371 & 172 & 32,609 & 1,606 & 4,652 & 189,319 & 24.8 \\
\hline Komi Republic & $16,250.7$ & $4,350,808$ & $4,514,277$ & $-176,152$ & $1,097,510$ & 440,959 & 137 & 95,025 & 10,347 & 50,055 & 500,987 & 24.3 \\
\hline Arkhangel'sk Oblast & $9,336.3$ & $2,299,123$ & $2,700,860$ & $-407,825$ & 703,535 & 309,177 & 33 & 32,695 & 2,118 & 21,131 & 338,381 & 26.0 \\
\hline Nenets Autonomous Okrug * & .. & 272,742 & 271,143 & 646 & 91,940 & 37,912 & 108 & 9,679 & 513 & 0 & 43,728 & 33.9 \\
\hline Vologda Oblast & $14,292.9$ & $2,570,754$ & $2,763,876$ & $-200,711$ & 720,456 & 277,465 & 2,401 & 60,182 & 4,997 & 12,240 & 363,171 & 26.1 \\
\hline Murmansk Oblast & $13,577.0$ & $2,480,063$ & $2,830,511$ & $-354,008$ & 728,942 & 384,376 & 24 & 46,505 & 7,442 & 19,668 & 270,927 & 25.8 \\
\hline Northwest & & $14,828,719$ & $17,311,018$ & $-2,558,048$ & $3,165,684$ & $1,227,949$ & 1,487 & 335,706 & 19,446 & 52,482 & $1,528,614$ & 18.3 \\
\hline St.Petersburg City & $9,753.9$ & $9,735,731$ & $11,910,628$ & $-2,229,021$ & $1,972,973$ & 695,518 & 798 & 253,479 & 0 & 33,573 & 989,605 & 16.6 \\
\hline Leningrad Oblast & $7,466.9$ & $2,612,215$ & $2,802,423$ & $-203,540$ & 581,535 & 278,623 & 273 & 38,698 & 3,004 & 11,870 & 249,067 & 20.8 \\
\hline Novgorod Oblast & $5,923.8$ & $1,292,044$ & $1,313,748$ & $-26,709$ & 311,455 & 125,325 & 273 & 21,356 & 2,496 & 5,173 & 156,832 & 23.7 \\
\hline Pskov Oblast & $5,538.9$ & $1,188,729$ & $1,284,219$ & $-98,778$ & 299,721 & 128,483 & 143 & 22,173 & 13,946 & 1,866 & 133,110 & 23.3 \\
\hline Central & .. & $76,259,173$ & $76,750,423$ & .. & $12,923,360$ & $4,433,178$ & 1,876 & $1,134,323$ & 150,392 & 710,842 & $6,492,749$ & 16.8 \\
\hline Bryansk Oblast & $5,272.3$ & $1,610,111$ & $1,684,723$ & $-81,377$ & 472,150 & 189,035 & 0 & 54,875 & 4,765 & 13,316 & 210,159 & 28.0 \\
\hline Vladimir Oblast & $6,487.6$ & $2,377,836$ & $2,469,165$ & $-101,163$ & 661,626 & 217,730 & 0 & 39,556 & 4,644 & 17,389 & 382,307 & 26.8 \\
\hline Ivanovo Oblast & $5,070.6$ & $1,609,454$ & $1,731,868$ & $-126,725$ & 380,890 & 144,263 & 0 & 21,350 & 4,639 & 696 & 209,942 & 22.0 \\
\hline Kaluga Oblast & $7,413.4$ & $1,692,626$ & $1,696,869$ & $-9,528$ & 379,921 & 164,128 & 383 & 34,898 & 1,671 & 2,103 & 176,738 & 22.4 \\
\hline Kostroma Oblast & $7,330.8$ & $2,026,512$ & $2,186,477$ & $-165,617$ & 355,001 & 135,005 & 8 & 31,384 & 2,488 & 6,142 & 179,974 & 16.2 \\
\hline Moscow City & $16,611.7$ & $41,137,173$ & $40,556,838$ & 299,976 & $5,403,700$ & $1,560,459$ & 300 & 410,440 & 88,537 & 516,844 & $2,827,120$ & 13.3 \\
\hline Moscow Oblast & $7,201.2$ & $13,404,234$ & $13,695,798$ & $-347,125$ & $2,537,364$ & 906,204 & 0 & 282,487 & 29,073 & 103,453 & $1,216,147$ & 18.5 \\
\hline Orel Oblast & $6,580.5$ & $1,357,799$ & $1,349,952$ & 1,634 & 353,913 & 142,787 & 111 & 39,096 & 2,056 & 3,798 & 166,065 & 26.2 \\
\hline Ryazan' Oblast & $7,847.3$ & $1,794,300$ & $1,862,509$ & $-74,429$ & 390,508 & 150,026 & 215 & 35,738 & 2,093 & 3,412 & 199,024 & 21.0 \\
\hline Smolensk Oblast & $6,692.4$ & $1,404,842$ & $1,406,027$ & $-9,986$ & 407,444 & 162,733 & 216 & 46,604 & 1,290 & 9,737 & 186,864 & 29.0 \\
\hline Tver' Oblast & $7,033.7$ & $2,417,737$ & $2,461,429$ & $-51,483$ & 541,636 & 200,694 & 416 & 56,844 & 5,468 & 18,691 & 259,523 & 22.0 \\
\hline Tula Oblast & $6,833,1$ & $2,541,267$ & $2,605,683$ & $.73,092$ & 473,533 & 214,336 & 128 & 43,719 & 1,800 & 8,109 & 205,441 & 18.2 \\
\hline Yaroslavl' Oblast & $10,155.5$ & $2,885,282$ & $3,043,085$ & $-173,035$ & 565,674 & 245,778 & 99 & 37,332 & 1,868 & 7,152 & 273,445 & 18.6 \\
\hline Volgo-Vyatka & .. & $12,956,200$ & $13,361,146$ & & $3,065,293$ & $1,188,315$ & 838 & 252,301 & 26,617 & 120,436 & $1,476,786$ & 22.9 \\
\hline Mari-El Republic & $5,124.8$ & $1,019,852$ & $1,059,488$ & $-42,690$ & 289,272 & 108,204 & 212 & 22,133 & 5,404 & 13,263 & 140,056 & 27.3 \\
\hline Mordvinian Republic & 5.233 .4 & $1,605,460$ & $1,700,290$ & $-96,500$ & 335,981 & 126,360 & 0 & 25,453 & 2.715 & 9,963 & 171,490 & 19.8 \\
\hline Chuvash Republic & $5,525.2$ & $1.933,437$ & $2,095,552$ & $-169,011$ & 490,736 & 190,848 & 75 & 30,778 & 1,918 & 43.923 & 223.194 & 23.4 \\
\hline Kirov Oblast & 7.168 .1 & $2,207.324$ & 2.289 .321 & -89.771 & 599.320 & 247.803 & 81 & 44,602 & 4.807 & 10.084 & 291,943 & 26.2 \\
\hline
\end{tabular}


Annex G4: Selected Data on Education Financy by Region in Russia

\begin{tabular}{|c|c|c|c|c|c|c|c|c|c|c|c|c|}
\hline & \multirow{2}{*}{$\begin{array}{l}\text { Gross Regional } \\
\text { Product per } \\
\text { Capita }\end{array}$} & \multirow{2}{*}{ Total revenues } & \multirow[t]{2}{*}{$\begin{array}{c}\text { Total } \\
\text { expenditures }\end{array}$} & \multirow[t]{2}{*}{ Budget Deficit } & \multicolumn{6}{|c|}{ Expenditures on Education, 1996} & \multirow[b]{2}{*}{ Other } & \multirow[b]{2}{*}{$\begin{array}{l}\text { Expenses as } \\
\text { share of } \\
\text { total }\end{array}$} \\
\hline & & & & & Total & Salaries & Medicine & Meals & $\begin{array}{l}\text { Capital } \\
\text { investinents }\end{array}$ & Civil works & & \\
\hline Nizhegorod Oblast & $9, \overline{420.2}$ & $6,190,127$ & $6,216,495$ & $-50,420$ & $1,349,984$ & 515,100 & 470 & 129,335 & 11,773 & $43, \overline{203}$ & 650,103 & $\overline{21.7}$ \\
\hline Central Chernozem & .. & $11,378,001$ & $11,926,325$ & & $2,712,010$ & $1,056,994$ & 1,024 & 230,309 & 27,718 & 130,472 & $1,265,493$ & 22.7 \\
\hline Belgorod Oblast & $8,598.7$ & $1,902,624$ & $2,061,787$ & $-166,113$ & 629,566 & 238,692 & 315 & 52,070 & 5,492 & 70,663 & 262,334 & 30.5 \\
\hline Voronezh Oblast & $6,600.0$ & $2,981,435$ & $3,147,711$ & $-179,101$ & 781,393 & 291,468 & 218 & 70,806 & 11,987 & 16,159 & 390,755 & 24.8 \\
\hline Kursk Oblast & $7,137.8$ & $2,092,441$ & $2,265,392$ & $-182,121$ & 416,321 & 171,839 & 309 & 31,862 & 4,365 & 18,991 & 188,955 & 18.4 \\
\hline Lipetsk Oblast & $11,034.9$ & $2,737,636$ & $2,774,189$ & $-45,264$ & 451,101 & 187,276 & 0 & 35,144 & 2,713 & 17,130 & 208,838 & 16.3 \\
\hline Tambov Oblast & $4,987,3$ & $1,663,865$ & $1,677,246$ & $-21,275$ & 433,629 & 167,719 & 182 & 40,427 & 3,161 & 7,529 & 214,611 & 25.9 \\
\hline Volga & & $31,617,309$ & $33,616,784$ & .. & $7,340,570$ & $3,019,479$ & 5,321 & 550,785 & 106,992 & 415,064 & $3,242,929$ & 21.8 \\
\hline Kalmyk Republic & $2,789.9$ & 549,712 & 673,229 & $-124,651$ & 167,039 & 70,023 & 40 & 11,871 & 901 & 2,717 & 81,487 & 24.8 \\
\hline Tatarstan Republic & $10,067.2$ & $10,046,436$ & $10,857,278$ & $-828,454$ & $2,253,465$ & 939,982 & 816 & 179,302 & 57,780 & 184,316 & 891,269 & 20.8 \\
\hline Astrakhan' Oblast & $5,597,7$ & $1,546,387$ & $1,809,258$ & $-269,727$ & 400,420 & 177,549 & 271 & 23,983 & 5,604 & 12,744 & 180,269 & 22.1 \\
\hline Volgograd Oblast & $7,272.7$ & $4,373,025$ & $4,523,381$ & $-162,534$ & $1,000,314$ & 437,454 & 936 & 61,236 & 12,440 & 29,603 & 458,645 & 22.1 \\
\hline Penza Oblast & $4,779.3$ & $1,711,851$ & $1,744,553$ & $-38,049$ & 459,958 & 188,509 & 1,159 & 40,096 & 3,662 & 23,425 & 203,107 & 26.4 \\
\hline Samara Oblast & $13,611.7$ & $7,586,003$ & $7,704,916$ & $-141,744$ & $1,767,633$ & 681,570 & 1,450 & 146,719 & 14,883 & 96,965 & 826,046 & 22.9 \\
\hline Saratov Oblast & $7,456.2$ & $3,952,489$ & $4,162,268$ & $-227,538$ & 889,140 & 333,364 & 495 & 62,407 & 9,580 & 46,816 & 436,478 & 21.4 \\
\hline Ul'yanovsk Oblast & $7,160.6$ & $1,851,406$ & $2,141,901$ & $-296,102$ & 402,601 & 191,028 & 154 & 25,171 & 2,142 & 18,478 & 165,628 & 18.8 \\
\hline North Caucasus & & $20,689,959$ & $22,270,785$ &. & $5,422,719$ & $2,391,081$ & 1,808 & 359,723 & 60,387 & 88,300 & $2,521,420$ & 24.3 \\
\hline Adygey Republic & $4,085.4$ & 545,442 & 567,824 & $-23,749$ & 137,266 & 61,063 & 0 & 5,484 & 3,218 & 28 & 67,473 & 24.2 \\
\hline Dagestan Republic & $1,992.1$ & $1,728,579$ & $2,202,626$ & $-475,417$ & 684,976 & 364,851 & 53 & 48,171 & 8,183 & 3,320 & 260,398 & 31.1 \\
\hline Ingushetia Republic & $1,940.4$ & 209,280 & 594,482 & $-385,202$ & 63,578 & 29,496 & 15 & 9,680 & 566 & 0 & 23,821 & 10.7 \\
\hline Kabardino-Balkar Republic & $3,325.8$ & $1,148,652$ & $1,376,782$ & $-230,464$ & 331,301 & 137,861 & 0 & 17,606 & 4,273 & 20,132 & 151,429 & 24.1 \\
\hline Karachay-Cherkess Republic & $3,903.0$ & 458,656 & 509,724 & $-52,877$ & 146,137 & 58,683 & 22 & 10,191 & 335 & 2.483 & 74,423 & 28.7 \\
\hline Nortlı Ossetian Republic & $3,526.6$ & $1,103,996$ & $1,153,364$ & -50.906 & 195,499 & 98,613 & 1 & 11,408 & 79 & 9,416 & 75,982 & 17.0 \\
\hline Checheniya Republic & & 495,431 & 479,503 & 15,928 & 82,093 & 53,630 & 0 & 0 & 0 & 0 & 28,463 & 17.1 \\
\hline Krasuodar Kray & $6,159.0$ & $6,555,728$ & $6,612,146$ & $.95,837$ & $1,731,438$ & 692,002 & 0 & 102,172 & 28,503 & 22,032 & 886,729 & 26.2 \\
\hline Stavropol' Kray & $6,835.1$ & $3,326,273$ & $3,428,564$ & $-121,147$ & 780,574 & 366,887 & 0 & 67,456 & 7,703 & 24,351 & 314,177 & 22.8 \\
\hline Rostov Oblast & $5,949.1$ & $5,117,922$ & $5,345,770$ & $-240,149$ & $1,269,857$ & 527,995 & 1,717 & 87,555 & 7.527 & 6,538 & 638,525 & 23.8 \\
\hline Urals & & $42,900,586$ & $44,225,584$ &. & $10,373,011$ & $3,900,556$ & 5,062 & 826,405 & 179,409 & 411,854 & $5,049,725$ & 23.5 \\
\hline Baslkkortostan Republic & $9,645.8$ & $10.744,286$ & $11,166,214$ & $-471,627$ & $2,442,712$ & 939,669 & 940 & 136,239 & 37,100 & 137,017 & $1,191,747$ & 21.9 \\
\hline Udmurt Republic & 7.593 .2 & 3.353 .650 & $3.464,541$ & -123.542 & 814,603 & 312,108 & 107 & 41.404 & 6.529 & 68.590 & 385,865 & 23.5 \\
\hline Kurgan Oblast & 5.690 .9 & $1,464,897$ & $1,579,125$ & -119.298 & 460.814 & 179.479 & 221 & 40.796 & 9.459 & 8.301 & 222,558 & 29.2 \\
\hline Orenburg Oblast & 8.147 .4 & 3.764 .080 & 3.910 .059 & -163.715 & 920.515 & 355,544 & 6.3 & 42.161 & 11.119 & 58.591 & 453.037 & 23.5 \\
\hline
\end{tabular}


Annex G4: Selected Data on Education Financy by Region in Russia

\begin{tabular}{|c|c|c|c|c|c|c|c|c|c|c|c|c|}
\hline & $\begin{array}{l}\text { Gross Regional } \\
\text { Product per }\end{array}$ & Total revenues & $\begin{array}{c}\text { Total } \\
\text { expenditures }\end{array}$ & Budget Deficit & & Expend & litures on $\mathbf{E}$ & lucation, 1 & & & & \\
\hline & & & & & Total & Salaries & Medicine & Meals & $\begin{array}{l}\text { Capita } \\
\text { investments }\end{array}$ & Civil works & Other & $\begin{array}{l}\text { Education } \\
\text { expenses as } \\
\text { total }\end{array}$ \\
\hline Perm Oblast & $12,291.5$ & $5,790,673$ & $5,781,044$ & $-17,542$ & $1,481,972$ & 534,342 & 1,471 & 113,400 & 32,582 & 42,233 & 757,944 & $\overline{25.6}$ \\
\hline Koni-Permyak Aut. Okrug * &.. & 187,355 & 225,021 & $-38,108$ & 86,436 & 40,258 & 0 & 8,077 & 0 & 0 & 38,101 & 38.4 \\
\hline Sverdlovsk Oblast & $12,376.0$ & $10,243,488$ & $10,659,635$ & $-433,558$ & $2,591,813$ & 967,039 & 1,863 & 219,298 & 45,995 & 49,995 & $1,307,623$ & 24.3 \\
\hline Chelyabinsk Oblast & $8,967.3$ & $7,539,512$ & $7,664,966$ & $-148,781$ & $1,660,582$ & 612,375 & 397 & 233,107 & 36,625 & 47,127 & 730,951 & 21.7 \\
\hline West Siberia & .. & $28,552,891$ & $30,537,250$ & & $6,690,421$ & $2,765,197$ & 3,332 & 402,046 & 76,600 & 132,707 & $3,310,539$ & 21.9 \\
\hline Altay Republic & $4,512.5$ & 282,104 & 364,729 & $-83,343$ & 133,017 & 59,522 & 19 & 7,042 & 819 & 3,767 & 61,848 & 36.5 \\
\hline Altay Kray & $5,526.8$ & $4,062,052$ & $4,622,539$ & $-577,409$ & $1,091,283$ & 424,570 & 342 & 55,322 & 8,000 & 17,700 & 585,349 & 23.6 \\
\hline Kemerovo Oblast & $11,844.8$ & $8,484,184$ & $8,735,386$ & $-271,607$ & $1,831,384$ & 819,450 & 1,433 & 153,370 & 19,223 & 0 & 837,908 & 21.0 \\
\hline Novosibirsk Oblast & $8,377.4$ & $4,626,387$ & $5,097,859$ & $-492,659$ & $1,141,107$ & 464,356 & 327 & 52,930 & 9,080 & 27,733 & 586,681 & 22.4 \\
\hline Omsk Oblast & $9,532.8$ & $4,209,181$ & $4,691,918$ & $-492,477$ & 974,437 & 390,664 & 349 & 49,290 & 8,524 & 19,301 & 506,309 & 20.8 \\
\hline Tomsk Oblast & $11,896.0$ & $2,564,897$ & $2,689,018$ & $-139,087$ & 645,669 & 256,669 & 368 & 45,016 & 12,570 & 20,225 & 310,821 & 24.0 \\
\hline Tyumen' Oblast & $34,421.4$ & $4,324,086$ & $4,335,801$ & $-29,712$ & 873,524 & 349,966 & 494 & 39,076 & 18,384 & 43,981 & 421,623 & 20.1 \\
\hline Khanty-Mansiy Aut. Okrug * & .. & $15,560,544$ & $15,698,570$ & $-243,061$ & $2,464,477$ & 891,736 & 1,303 & 113,567 & 79,246 & 212,836 & $1,165,789$ & 15.7 \\
\hline Yamal-Nenets Aut. Okrug * &.. & $7,539,890$ & $7,771,514$ & $-245,661$ & $1,054,515$ & 283,743 & 1,403 & 71,326 & 84,586 & 0 & 613,457 & 13.6 \\
\hline East Siberia & .. & $17,957,236$ & $19,266,700$ & .. & $4,927,091$ & $2,196,718$ & 2,579 & 330,542 & 64,296 & 208,041 & $2,124,915$ & 25.6 \\
\hline Buryat Republic & $7,350.0$ & $1,716,535$ & $2,090,446$ & $-379,391$ & 553,073 & 214,176 & 747 & 30,695 & 5,378 & 1,956 & 300,121 & 26.5 \\
\hline Tuva Republic & $3,523.0$ & 481,603 & 651,598 & $-170,867$ & 239,937 & 119,138 & 0 & 22,539 & 177 & 1,210 & 96,873 & 36.8 \\
\hline Khakass Republic & $8,704.7$ & $1,078,696$ & $1,174,050$ & $-99,480$ & 287,368 & 114,406 & 197 & 17,768 & 3,367 & 18,696 & 132,934 & 24.5 \\
\hline Krasnoyarsk Kray & $14,173.8$ & $6,772,457$ & $7,131,415$ & $-361,447$ & $1,754,444$ & 737,766 & 488 & 106,689 & 38,322 & 94.098 & 777,081 & 24.6 \\
\hline Taymyr Autonomous Okruy * & .. & 231,622 & 296,562 & $-66,136$ & 111.370 & 35,554 & 63 & 7,138 & 2,484 & 0 & 66,131 & 37.6 \\
\hline Evenki Autonomous Okrug * &. & 235,476 & 252,832 & $-17,557$ & 40,063 & 18,151 & 25 & 5,725 & 292 & 71 & 15,799 & 15.8 \\
\hline Irkutsk Oblast & $12,251.3$ & $6,014,233$ & $6.247,336$ & $-240,497$ & $1,503,423$ & 769,025 & 1,026 & 111,150 & 15,166 & 85.750 & 521,306 & 24.1 \\
\hline Ust'-Orda Buryat Aut. Okrug * &.. & 249,853 & 265,589 & $-16,784$ & 91.837 & 46,533 & 40 & 6,582 & 2,197 & 0 & 36,485 & 34.6 \\
\hline Chita Oblast & $7,738.7$ & $1,893,712$ & $1,971,855$ & $-84,903$ & 588,846 & 242,207 & 121 & 41,701 & 1,886 & 6,331 & 296,600 & 29.9 \\
\hline Aga Buryat Autonoinous Okrug * & .. & 86,490 & 159,375 & $-72,887$ & 60,570 & 30,574 & 0 & 1,549 & 0 & 0 & 28,447 & 38.0 \\
\hline Far East &.. & $23,576,282$ & $27,790,083$ & & $6,656,339$ & $2.801,538$ & 2,643 & 497,026 & 40,363 & 119.909 & $3,194,860$ & 24.0 \\
\hline Sakha Republic (Yakutia) & $19,756.0$ & $5,328,304$ & $8,223,489$ & $-2,908,742$ & $2,218,286$ & 955,349 & 448 & 156,143 & 24,389 & 53.896 & $1,028,061$ & 27.0 \\
\hline Jewish Autonomous Oblast & $5,637.1$ & 332,399 & 371,656 & $-40,283$ & 111,037 & 44,968 & 0 & 9,481 & 322 & 0 & 56,266 & 29.9 \\
\hline Chukotka Autonomous Okrug & {$[4,138.7$} & $1,126,926$ & $1,259,278$ & $-134,067$ & 291,220 & 100,947 & 91 & 46.875 & 301 & 4,302 & 138,704 & 23.1 \\
\hline Prinorskiy Kray & 8.519 .3 & $4,586,297$ & 4.843 .006 & -273.136 & $1,063,877$ & 483,531 & 394 & 71.170 & 3.101 & 10.413 & 495.268 & 22.0 \\
\hline Khabarovsk Kray & 9.543 .0 & 4.234 .584 & 4.501 .535 & -278.093 & 1.131 .134 & 456,881 & 456 & 82,603 & 5.626 & 30.001 & 555.567 & 25.1 \\
\hline Amur Oblast & 8.011 .4 & 2.399 .679 & $2.465,827$ & -73.671 & 515.605 & 196.368 & 815 & 27.313 & 1.616 & 9.652 & 279.841 & 20.9 \\
\hline
\end{tabular}


Annex G4: Selected Data on Education Financy by Region in Russia

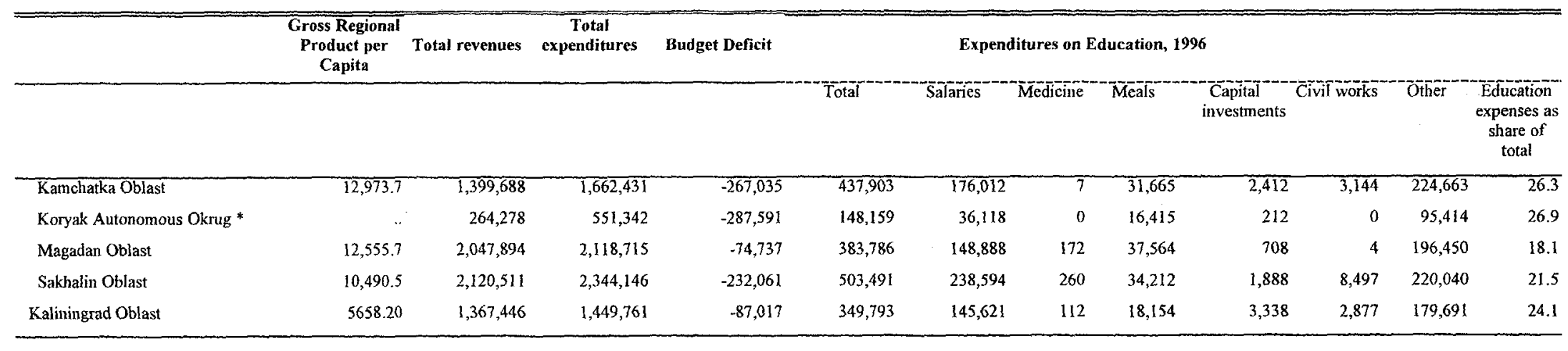

Sources and notes: Education expenditures data are from Ministry of Education. Other revenue and expenditure data are from the Ministry of Finance. Household budget data are from separate tables. .. Means not available

* Data for these areas also included in larger geographic unit which they subordinate to. 


\section{Distributors of World Bank Group Publications}

\begin{tabular}{|c|}
\hline $\begin{array}{l}\text { Prices and credit terms vary from } \\
\text { counntry to country. Consult your } \\
\text { local distributor before placing an } \\
\text { order. }\end{array}$ \\
\hline $\begin{array}{l}\text { ARGENTINA } \\
\text { World Publications SA } \\
\text { Av. Corcoba } 1877 \\
1120 \text { Cliddad de Buenos Aires } \\
\text { Tel: (54 11) } 4815-8156 \\
\text { Fax: (54 11) } 4815-8156 \\
\text { E-mail: wpbooks@infovia.com.ar }\end{array}$ \\
\hline 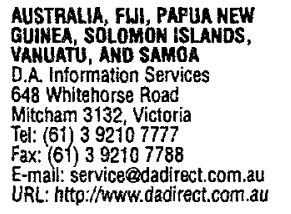 \\
\hline $\begin{array}{l}\text { AUsTRIA } \\
\text { Gerold and Co. } \\
\text { Weihburgasse } 26 \\
\text { A-101 1 Wien } \\
\text { Tel: ( } 43 \text { 1 } 512-47-31-0 \\
\text { Fax: (43 1) } 512-47-31-29 \\
\text { URL: hitp://wwww.gerold.co/at.online }\end{array}$ \\
\hline $\begin{array}{l}\text { BAMGLADESH } \\
\text { Micro Industries Development } \\
\text { Assistance Society (MIDAS) } \\
\text { House } 5 \text {, Road } 16 \\
\text { Ohanmondi R/Area } \\
\text { Dhaka 1209 } \\
\text { Tel: }(8802) 326427 \\
\text { Fax: (880 2) } 811188\end{array}$ \\
\hline $\begin{array}{l}\text { BELGIUM } \\
\text { Jean De Lannoy } \\
\text { Av. du Roi } 202 \\
\text { 1060 Brussels } \\
\text { TEl: (32 2) } 538-5169 \\
\text { Fax: (32 2) } 538-0841\end{array}$ \\
\hline 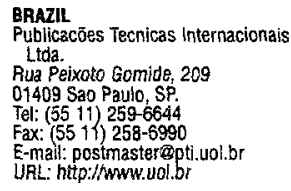 \\
\hline $\begin{array}{l}\text { CANADA } \\
\text { Rerouf Pubishing Co. Ltd. } \\
5369 \text { Canotek Road } \\
\text { Ottawa, Ontario KIJ } 933 \\
\text { Fel: (613) 745-2665 } \\
\text { Fax: (613) 745-7660 } \\
\text { E-mail: } \\
\text { order.dept@renoufbooks.com } \\
\text { URL: hittp:// www.renoufbooks.com }\end{array}$ \\
\hline $\begin{array}{l}\text { CHINA } \\
\text { China Financial \& Economic } \\
\text { Publishing House } \\
\text { 8, Da Fo Si Dong Jie } \\
\text { 8eijing } \\
\text { Tel: (86 10) } 6401-7365 \\
\text { Fax: }(86 \text { 10) } 6401-7365\end{array}$ \\
\hline $\begin{array}{l}\text { China Book Import Centre } \\
\text { P.0. Box } 2825 \\
\text { Beiling }\end{array}$ \\
\hline $\begin{array}{l}\text { Chinese Corporation for Promotion } \\
\text { of Humanities } \\
52 \text { Y Yu Fang Hu Tong. } \\
\text { Xuan Nei Da Jie } \\
\text { Beiling } \\
\text { Tel: : } 86 \text { 10) } 66072494 \\
\text { Fax: }(8610) 66072484\end{array}$ \\
\hline $\begin{array}{l}\text { CoLomaik } \\
\text { infoeniace Ltda. } \\
\text { Carreta } 6 \text { No. } 51-21 \\
\text { Apartado Aereo } 34270 \\
\text { Santaté de Bogota, D.C. } \\
\text { Tel: (57 1) 285-2798 } \\
\text { Fax: (57 1) 285-2798 }\end{array}$ \\
\hline $\begin{array}{l}\text { CoTE D'volRE } \\
\text { Center d'Edition et de Diffusion } \\
\text { Africaines (CEDA) } \\
\text { O4 B.P. } 541 \\
\text { Abidijan O4 } \\
\text { Tel: (225) } 246510 ; 246511 \\
\text { Fax: }(225) 250567\end{array}$ \\
\hline $\begin{array}{l}\text { CYPRUS } \\
\text { Center for Applied Research } \\
\text { cyprus College } \\
\text { 5. Diogenes street, Engomi } \\
\text { P.o. Box 2006 } \\
\text { Nicosia } \\
\text { Tel: }(3572) 59-0730 \\
\text { Fax: }\{3572\} 65-2051\end{array}$ \\
\hline
\end{tabular}

\begin{tabular}{|c|}
\hline 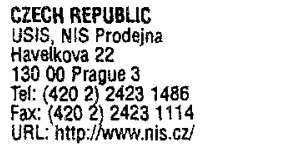 \\
\hline 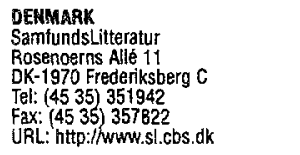 \\
\hline 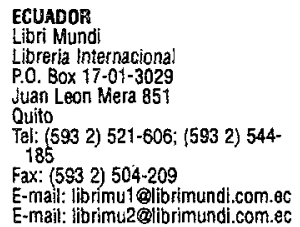 \\
\hline $\begin{array}{l}\text { CODEu } \\
\text { Ruiz de Castilla 763, Edif. Expocolor } \\
\text { Primer pisc, Of. } \$ 2 \\
\text { Quito } \\
\text { Telifax: (5932) } 507-383 ; 253-091 \\
\text { E-mail: codeu@impsat.net.ec }\end{array}$ \\
\hline $\begin{array}{l}\text { EGYPT, ARAB REPUBLIC OF } \\
\text { Af Ahram Distribution Agency } \\
\text { Al Galaa Street } \\
\text { Cairo } \\
\text { Tel: (20 2) } 578-6083 \\
\text { Fax: (202) } 578-6833\end{array}$ \\
\hline $\begin{array}{l}\text { The Middle East Observer } \\
\text { 41, Sherif Street } \\
\text { Cairo } \\
\text { Tel: }(202) 393-9732 \\
\text { Fax: }(202) 393-9732\end{array}$ \\
\hline 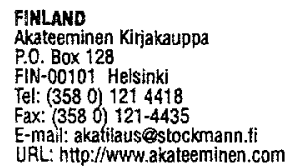 \\
\hline $\begin{array}{l}\text { FRANCE } \\
\text { Editions Eska; DB.J } \\
\text { 48, rue Gay Lussac } \\
\text { 75005 Paris } \\
\text { Tel: }(33-1) \text { 55-42-73-08 } \\
\text { Fax: (33-1) } 43-29-91-67\end{array}$ \\
\hline 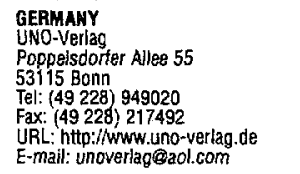 \\
\hline $\begin{array}{l}\text { GHANA } \\
\text { Epp Books Services } \\
\text { P.O. BOX } 44 \\
\text { TUC } \\
\text { Accra } \\
\text { Tel: } 22321778843 \\
\text { Fax: } 22321779099\end{array}$ \\
\hline 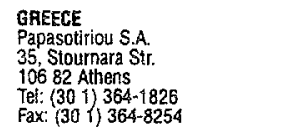 \\
\hline $\begin{array}{l}\text { HAMT } \\
\text { Cuiture Diffusion } \\
5, \text { Rue Capois } \\
\text { C.P. } 257 \\
\text { Port-aL-Prince } \\
\text { Tel: (509) } 239260 \\
\text { Fax: }(509) 234858\end{array}$ \\
\hline $\begin{array}{l}\text { HOKG KONG, CHINA; MACAO } \\
\text { Asla } 2000 \text { Lto. } \\
\text { Sales \& Circulation Department } \\
302 \text { Seabird House } \\
\text { 22-28 Wyndham Street, Central } \\
\text { Hong Kong, China } \\
\text { Tel: (852) } 2530-1409 \\
\text { Fax: (852) 2526-1107 } \\
\text { E-mail: sales@@asia2000.com.hk } \\
\text { UAL: http://WwW.asia2000.com.hk }\end{array}$ \\
\hline $\begin{array}{l}\text { HUNGAAY } \\
\text { Euro Info Service } \\
\text { Margitszgetl Europa Haz } \\
\text { H-1 138 Budapest } \\
\text { Tel: (36 1) } 3508024,3508025 \\
\text { Fax: (36 1) } 35090 \quad 32 \\
\text { E-mall: euroinfo@mail.matav.hu }\end{array}$ \\
\hline
\end{tabular}

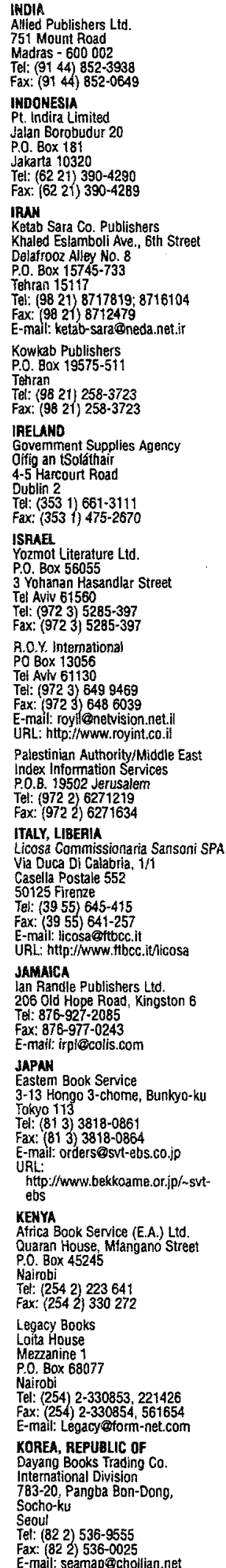

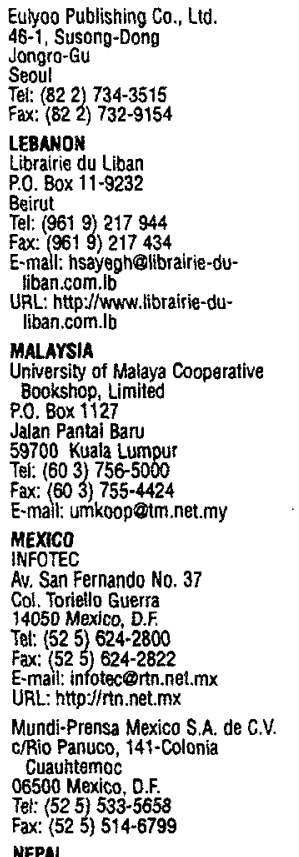

MEPAL
Everest Media International Services GPO BOX 5443

Kathmandu 416026

Fax: (977) 224431

NETHERLAHDS
De Lindeboom/nternationale

Publlcaties b.V.-
P. $80 x 202,7480$ AE Haaksbergen Tel: (3153) $574-0004$

E-mail: lindeboogeworidonline.nl URL: http://www.worldonine.n//lin-

MEW ZEALAND

EBSCO N2 Ltt.

New Market

Tel: $(649) 524-8119$

Tel: (64.9) $524-8119$
Fax: (64 9) $524-8067$

Oasis Otticial

P.o. Box 3627

Well: (64 4) 4991551

Fax: (64 4) 4991972

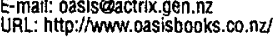

MIGERIA

University Press Limited

Three Crowns Building Jericho

Tol: (234 22) $41-1356$
Fax: (234 22) $41-2056$

Pakistan

Mirza Book Agenoy

65. Shahtrah-e-Quaid-e-Azam

Tel: (92 42) 7353601

(2) 42) 5763714

5 Bangalore Town

Sharae Faisal

PO Box 13033

Tel: (92 21) 446307

E-mail: ouppak@TheOffice.net

Pak Book Corporation

Aziz Chambers 21, Queen's Road

Tel: (928 42) 636 3222; 6360885

Fax: (92 42$) 6362328$

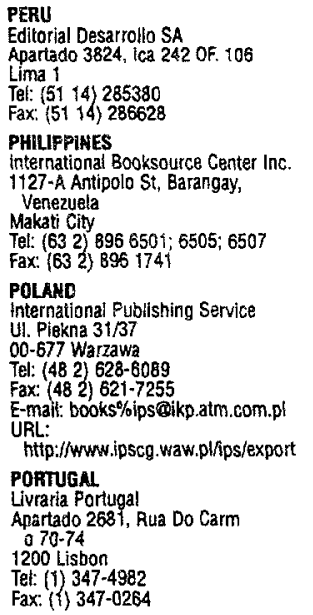

romania

Compani De Librazii Bucuresti S.A.

Str. Lipscani no. 26, sector 3

Buch (40 1) 3139645

RUSSIAN FEDERATIOH

sdatelstivo < Ves Mitis

9a, Ko:pachniy Pereulok
Moscow to1831

Fel: (7095) 9178749

ozimarin@glasnet.ru

SIMGAPORE; TAWAA, CHIMA

Hemisphere Publication Services

41 Kallang Pudding Moad \#04-03

Golden Wheel Building

Singapore 349316

Te: $(65) 741-5166$

E-mail: ashgate Qasianconnect.com SLOVENU

Gospodarski vestnik Publishing

Group

1000 (jubljana

Fax: (3866 6) 1338030

E-mail: repanseki@gvestnik.si

SOUTH AFRICA, EOTSWANA

For single titles:
Oxtord University Press Southern

Aascica Boulevard, Goodwood

P.O. 80x 12119, N1 Ciky 7463

Capel: (27 21) 5954400

Fax: (27 2) 5954430

For subscription orders:

International Subscríption Service

P. 0. Box 41095

Craighall 2024

Tel: (27 11) 880-1448

Eax: (27) 1 is) $880-6248$

SPAN

SPAlN
Mandi-Prensa Libros, S.A.
Castello 37

Tel: : $(34,91) 4363700$

Ermail: iibreria@mundiprensa es

URL: http://wwww.mundiprensa.com/

Mundi-Prensa Barcelona

Consell de cent,

Tel: (34 33 488-3492

E-mail: barcelona@mundiprensa.es

SRI LANKA, THE MALDIVES

Lake House Bookshop

Mawatha

Tel: (94 1) 32105

F-max:: LFL

\author{
Wnergfen-Williams AB \\ . 0. BOX 1305 \\ Tel: $(468)$ 8) $705-97-50$ \\ E-mill: mailiowwi.se \\ SWITZEALAND \\ Wbrairie Payot Sevice institutionne \\ C(m)tes-de-Montbenon 30 \\ Tel: (41 21) $341-3229$ \\ ax: (41 21) $341-323$ \\ ADECO Van Diermen \\ EditionsTechniques \\ Ch. de Lacuez A1 \\ Tel: (41 21) 9432673 \\ (ax. (41 21) 9433605 \\ THALLAND \\ Central Books Distribution \\ 306 Silom Road \\ Bangkok 166 2) $2336930-9$ \\ Fax: (662) 237-8321 \\ FFIHIDAD \& TOBAGD \\ Systematics Studies Ltt. \\ St. Augustine Shopping Center
Eastern Main Road, St. Augustine \\ Trinidad \& Tobago West Incies \\ Tel: (868) 645-8466 \\ E-mall: tobe@itrinidad.nat \\ UGANDA \\ Gustro Litd. \\ PItot 16/4 Jinja Rd. \\ Kampala
Tel: (256 41) 251467
fax: (256 41$) 251468$ \\ Fax: (256 41) 251468
E-mall: guseswiftuganda.com \\ UATTED KAMGDOM \\ Microinfo Lto.
P.O. Box 3 , Omga Park, Atton,
Hampshire GU34 2PG \\ Tel: (44 1420) 26848 \\ Eax.: (44 1420) 89889 \\ URL: http:I/Www.microinto.co. ut \\ The Stationery Office \\ 51 Nine EIms Lane \\ Tel: (44 171) 873-8400 \\ URL: http://www.the-stationery- \\ office.co.tuk/ \\ VENEZUELA \\ Tecni-Ciencia Libros, S.A. \\ Centro Cuidad Comercial Tamanco \\ Tel: (58 2) 959 5547; 5035; 0016 \\ Fax: (58 2) 9595636 \\ ZAMiversity Bookshop, University of \\ Zambia \\ P. 0. Box 32379 \\ Luseika
Fal: (260 1) 252576
Fax: $(260$ ) 253952 \\ FaX: (260 \}) \\ Academic and Baobab Books (Pvt.) \\ 4 Conald Road, Graniteside \\ P. $0.80 \times 567$ \\ Tel: 2634755035 \\ Tel: 2634755035
Fax: 2634781913
}





\section{Recent World Bank Technical Papers (continued)}

No. 414 Salman and Boisson de Chazournes, International Watercourses: Enhancing Cooperation and Managing Conflict, Proceedings of a World Bank Seminar

No. 415 Feitelson and Haddad, Identification of Joint Management Structures for Shared Aquifers: A Cooperative Palestinian-Israeli Effort

No. 416 Miller and Reidinger, eds., Comprehensive River Basin Development: The Tennessee Valley Authority

No. 417 Rutkowski, Welfare and the Labor Market in Poland: Social Policy during Economic Transition

No. 418 Okidegbe and Associates, Agriculture Sector Programs: Sourcebook

No. 420 Francis and others, Hard Lessons: Primary Schools, Community, and Social Capital in Nigeria

No. 421 Gert Jan Bom, Robert Foster, Ebel Dijkstra, and Marja Tummers, Evaporative Air-Conditioning: Applications for Environmentally Friendly Cooling

No. 422 Peter Quaak, Harrie Knoef, and Huber Stassen, Energy from Biomass: A Review of Combustion and Gasification Technologies

No. 423 Energy Sector Unit, Europe and Central Asia Region, World Bank, Non-Payment in the Electricity Sector in Eastern Europe and the Former Soviet Union

No. 424 Jaffee, ed., Southern African Agribusiness: Gaining through Regional Collaboration

No. 425 Mohan, ed., Bibliography of Publications: Africa Region, 1993-98

No. 426 Rushbrook and Pugh, Solid Waste Landfills in Middle-and Lower-Income Countries: A Technical Guide to Planning, Design, and Operation

No. 427 Mariño and Kemper, Institutional Frameworks in Successful Water Markets: Brazil, Spain, and Colorado, USA

No. 428 C. Mark Blackden and Chitra Bhanu, Gender, Growth, and Poverty Reduction: Special Program of Assistance for Africa, 1998 Status Report on Poverty in Sub-Saharan Africa

No. 429 Gary McMahon, José Luis Evia, Alberto Pascó-Font, and José Miguel Sánchez, An Environmental Study of Artisanal, Small, and Medium Mining in Bolivia, Chile, and Peru

No. 430 Maria Dakolias, Court Performance around the World: A Comparative Perspective

No. 431 Severin Kodderitzsch, Reforms in Albanian Agriculture: Assessing a Sector in Transition

No. 432 Luiz Gabriel Azevedo, Musa Asad, and Larry D. Simpson, Management of Water Resources: Bulk Water Pricing in Brazil

No. 433 Malcolm Rowat and José Astigarraga, Latin American Insolvency Systems: A Comparative Assessment

No. 434 Csaba Csaki and John Nash, eds., Regional and International Trade Policy: Lessons for the EU Accession in the Rural Sector-World Bank/FAO Workshop, June 20-23, 1998

No. 436 Roy Prosterman and Tim Hanstad, ed., Legal Impediments to Effective Rural Land Relations in Eastern Europe and Central Asia: A Comparative Perspective

No. 437 Csaba Csaki, Michel Dabatisse, and Oskar Honisch, Food and Agriculture in the Czech Republic: From a "Velvet" Transition to the Challenges of EU Accession

No. 443 Luc Lecuit, John Elder, Christian Hurtado, François Rantrua, Kamal Siblini, and Maurizia Tovo, DeMIStifying MIS: Guidelines for Management Information Systems in Social Funds

No. 444 Robert F. Townsend, Agricultural Incentives in Sub-Saharan Africa: Policy Challenges

No. 445 Ian Hill, Forest Management in Nepal: Economics of Ecology

No. 446 Gordon Hughes and Magda Lovei, Economic Reform and Environmental Performance in Transition Economies

No. 447 R. Maria Saleth and Ariel Dinar, Evaluating Water Institutions and Water Sector Performance

No. 449 Keith Oblitas and J. Raymond Peter in association with Gautam Pingle, Halla M. Qaddumi, and Jayantha Perera, Transferring Irrigation Management to Farmers in Andhra Pradesh, India

No. 450 Andrés Rigo Sureda and Waleed Haider Malik, eds., Judicial Challenges in the New Millennium: Proceedings of the Second Summit of the Ibero-American Supreme Courts

No. 452 Lev Freinkman, Daniel Treisman, and Stephen Titov, Subnational Budgeting in Russia: Preempting a Potential Crisis

No. 454 Julia Bucknall, Poland: Complying with EU Environmental Legislature

No. 455 Dale F. Gray, Assessment of Corporate Sector Value and Vulnerability: Links to Exchange Rate and Financial Crises

No. 456 Salman M.A. Salman, ed., Groundwater: Legal and Policy Perspectives: Proceedings of a World Bank Seminar 


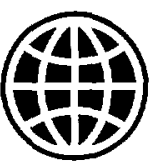

THE WORLD BANK

1818 H Street, N.W.

Washington, D.C. 20433 USA

Telephone: 202-477-1234

Facsimile: 202-477-6391

Telex: MCI 64145 WORLDBANK MCI 248423 WORLDBANK

Internet: www.worldbank.org

E-mail: hooks@worldbank.org

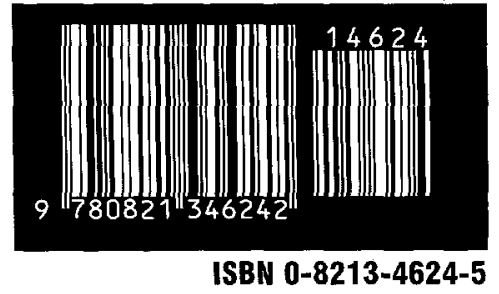

